\title{
Westinghouse Hanford Company Health and Safety Performance Report First Quarter Calendar Year 1995
}

Safety

Radiological Control

Date Published

May 1995

Prepared for the U.S. Department of Energy Assistant Secretary for Environment, Safety and Health 
WHC-SP-0564-37

\section{RELEASE AUTHORIZATION}

Document Number: $\quad$ WHC-SP-0564-37

Westinghouse Hanford Company Health and Safety

Performance Report - First Quarter Calendar Year 1995

Release Date: $\quad 5 / 11 / 95$

This document was reviewed following the procedures described in WHC-CM-3-4 and is:

APPROVED FOR PUBLIC RELEASE

WHC Information Release Administration Specialist:

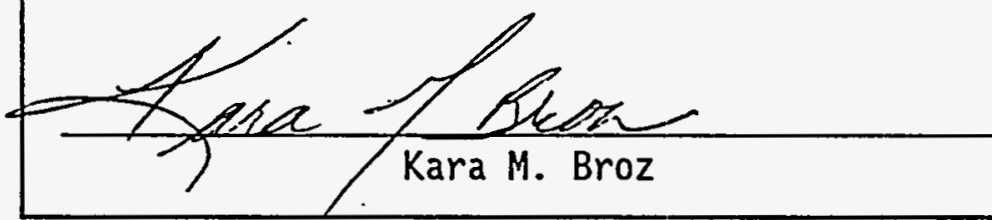

May 11, 1995 


\section{DISCLAIMER}

This report was prepared as an account of work sponsored by an agency of the United States Government. Neither the United States Government nor any agency thereof, nor any of their employees, make any warranty, express or implied, or assumes any legal liability or responsibility for the accuracy, completeness, or usefulness of any information, apparatus, product, or process disclosed, or represents that its use would not infringe privately owned rights. Reference herein to any specific commercial product, process, or service by trade name, trademark, manufacturer, or otherwise does not necessarily constitute or imply its endorsement, recommendation, or favoring by the United States Government or any agency thereof. The views and opinions of authors expressed herein do not necessarily state or reflect those of the United States Government or any agency thereof. 


\section{DISCLAIMER}

Portions of this document may be illegible in electronic image products. Images are produced from the best available original document. 
Document Title: Westinghouse Hanford Company Health and Safety Performance Report WHC-SP-0564-37

Prepared by:

Approved by:
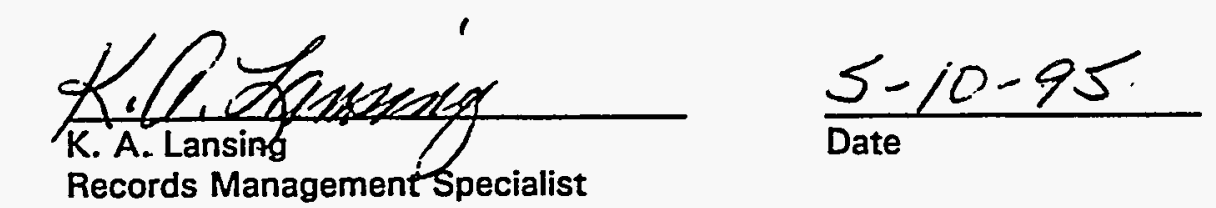
Records Management Specialist

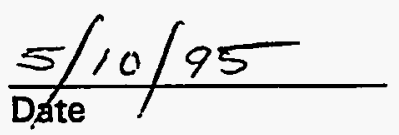

Approved by:

R. K. Kobelski

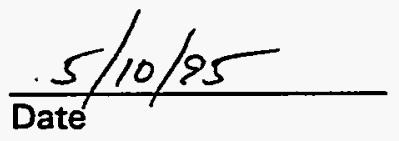
Manager, Industrial Safety and Fire Protection 


\section{WHC-SP-0564-37}

This page intentionally left blank. 


\section{ACKNOWLEDGEMENTS}

Authors, contributors, and reviewers of the Westinghouse Hanford Health and Safety Performance Report are all a part of the Emergency, Safety, Quality Services organization.

Section 1, "ALARA," O. D. Berglund, Editor

Radiological Control

Radiological Engineering and ALARA

O. D. Berglund, ALARA Coordinator

R. E. Elder, Senior Health Physicist

L. O. Waggoner, Senior Health Physicist

Section 2, "INDUSTRIAL SAFETY," J. J. Severud, Editor

Safety

Industrial Safety and Fire Protection

T. A. Bartley, Records Management Specialist

D. L. McCauley, Engineer

J. J. Severud, Records Management Specialist

D. J. Wiatrak, VPP Program Coordinator

Industrial Hygiene Programs

S. L. Wilkinson, Scientist

Protection Program Integration

M. B. Jaeger, Safeguard/Security Specialist

Health and Safety Training

D. E. Brock, Trainer/lnstructor

\section{Section 3, "RADIOLOGICAL SAFETY," K. A. Lansing, Editor}

Radiological Control

T. W. Hogg, Program Engineer

Radiological Engineering and ALARA

J. S. Konyu, Plant Engineer

Dosimetry

B. L. Baumann, Internal Dosimetry Advisor

G. W. Cramer, Senior Engineer

D. S. Cunningham, Principal Health Physicist

D. J. Gateley, Records Management Specialist

Safety

Industrial Safety and Fire Protection

K. A. Lansing, Records Management Specialist

S. L. Thackham, Clerk 
WHC-SP-0564-37

This page intentionally left blank. 


\section{MANAGEMENT SUMMARY}

During the first quarter of CY 1995, four of the WHC sitewide ALARA performance goals were completed on or ahead of schedule. One of the completed goals related to reduction of radiological areas at WHC-managed facilities. Due to anticipated resource reductions and increased scope of work, several facilities escalated their reduction schedule. This allowed the ALARA goal to be completed and exceeded ahead of schedule (page 1-1).

Detailed information pertaining to occupational injuries/illnesses is provided in Section 2.0.

Pages 2-8 and 2-9 show that the first quarter lost and/or restricted workday case rate was at about the same pace as that posted for CY 1994. Significant improvement, however, is shown in cases involving days away for injured workers (0.68 in CY 1994 to 0.29 for the first quarter of CY 1995). The strong reduction in the total number of days lost or restricted due to injury, which was achieved during 1994 , continued through the first quarter, as the rate of 13.40 was $67 \%$ lower than the CY 1994 rate of 40.70.

Industrial Safety and Health initiatives are being pursued in areas such as workplace ergonomics, safety training, and standards development. Positive efforts are ongoing in the areas of management commitment and employee involvement through the WHC Voluntary Protection Program. Successful implementation continues through the President's Accident Prevention Council (PAPC) and division employee Accident Prevention Councils. The Company now has established CY 1995 PAPC goals. These and other issues of significance are discussed on pages 2-1 through 2-6.

Summaries of the statistical performance of each organization are offered on pages 2-17 through 2-27. Highlighted this quarter are the indicators for lost workday away injuries, a category showing general improvement for the company.

Major programmatic accomplishments completed during this reporting period include the Department of Energy-Headquarters (DOE-HQ) formally endorsing the Radiological Control organization's approach toward development of the Radiation Protection Program (RPP) document. The DOE-HQ has recognized the significant contributions and leadership that Radiological Control has provided in planning and implementation of this "model example of an RPP" across the DOE complex and is encouraging other sites to contact WHC for assistance in developing their RPPs.

The radiological exposure results, presented on page 3-3, represent the exposure of 2,456 quarterly-badged employees and an average of 1,039 monthly-badged employees. The increased 


\section{MANAGEMENT SUMMARY (Continued)}

exposure shown for March is mainly attributed to higher dose-rate jobs and an increased amount of work performed by TWRS during the month.

There were four instances of potential loss of contamination control during the calendar quarter involving 11 workers where internal dosimetry follow-up was performed. No intakes of radioactive material were found and no internal dose was assessed for any of these cases (page 3-6).

There were eight skin contaminations reported during the first calendar quarter in WHCmanaged facilities/operations. The skin contaminations occurred at PFP (2), Analytical Laboratories (2), Tank Farms (1), PUREX (1), T Plant (1), and K Basins (1). Skin contamination events resulted in "very low" level exposures with no readings exceeding $10,000 \mathrm{dpm}$ beta/gamma or $700 \mathrm{dpm}$ alpha contamination. Twenty clothing contaminations were reported during this same period: Tank Farms (11), K Basins (2), PUREX (2), Analytical Laboratories (3), and PFP (2). Clothing contamination events resulted in contaminations identified as both "very low" and "low" level contaminations: $\geq 20,000$ but $<100,000 \mathrm{dpm}$ beta/gamma or $\geq 1,000 \mathrm{dpm}$ but $<40,000 \mathrm{dpm}$ alpha.

The total number of RPRs written this quarter was $218,32 \%$ fewer than the number written during the first quarter of 1994 and 1993. One reason for this decrease continues to be an increasingly cooperative effort between Radiological Control and the actionees to avoid radiological problems through a proactive approach. Also, a more concerted effort has been placed upon the prescreening of initial RPRs by the issuing management teams in order to ensure the accuracy and validity of the RPR process (page 3-12). 


\section{TABLE OF CONTENTS}

1.0 ALARA .................................. 1-1

1.1 WESTINGHOUSE HANFORD COMPANY ALARA GOALS $\ldots \ldots \ldots \ldots \ldots \ldots$ 1-1

1.1.1 Sitewide ALARA Performance Goals ................ 1-1

1.1.2 Facility/Organization ALARA Goal Performance ............ 1-1

1.2 ALARA/CCIP PROGRAM IMPLEMENTATION, PROGRESS, AND ACHIEVEMENTS 1-2

1.3 CONTAMINATION CONTROL IMPROVEMENT PROJECT $\ldots \ldots \ldots \ldots \ldots \ldots \ldots$

1.3.1 Airborne Radioactivity Areas . . . . . . . . . . . . . . . . 1-3

1.3.2 Indoor and Outdoor Contamination Area .............. 1-4

1.3.3 CA Reduction - Indoor and Outdoor Areas .............. 1-6

1.4 ALARA PROGRAM LESSONS LEARNED THROUGH POST ALARA REVIEWS . $1-7$

1.5 ALARA TRACKING AND MANAGEMENT SYSTEM $\ldots \ldots \ldots \ldots \ldots \ldots \ldots$ 1-8

1.6 ALARA TRAINING $\ldots \ldots \ldots \ldots \ldots \ldots \ldots \ldots \ldots \ldots \ldots \ldots \ldots \ldots$

1.9 ALARA POINTS OF CONTACT .................... 1-10

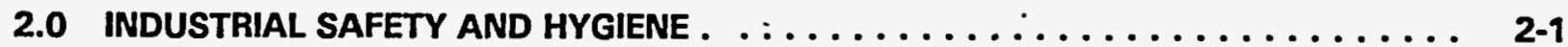

2.1 INTRODUCTION ............................ 2 .1

2.2 ONGOING INDUSTRIAL SAFETY AND HEALTH INITIATIVES $\ldots \ldots \ldots \ldots \ldots . . \ldots 2$

2.2.1 Voluntary Protection Program (VPP) ............... 2 .

2.2.2 Traffic Control .......................... 2-2

2.2.3 Electrical Safety ....................... $2-2$

2.2.4 Workstation Ergonomics .................... 2-2

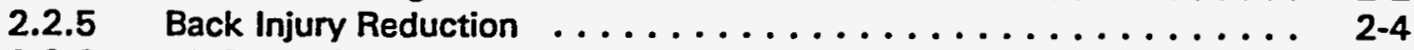

2.2.6 All Strain/Sprain Injury Reduction ................. 2-5

2.3 CHALLENGES AHEAD/LESSONS LEARNED $\ldots \ldots \ldots \ldots \ldots \ldots \ldots \ldots \ldots$

2.3.1 Consolidation of Safety Standards ................. 2-6

2.3.2 . Safety Meeting Improvement ... . . . . . . . . . . . . . . 2-6

2.3.3 Significant Safety/Health Events .................. 2-6

2.4 TOPICS OF INTEREST . . . . . . . . . . . . . . . . . . . . . 2 2-6

2.4 .1 Safety Resource Center ................... 2-6

2.5 COMPANY-WIDE AND DEPARTMENT-LEVEL TRENDING AND ANALYSIS $\ldots 2$

2.5.1 Occupational Injury/liness Incidence Rates .............. 2-8

2.5.2 Lost/Restricted Workday Case Incidence Rates ............ 2-9

2.5.3 Lost/Restricted Workday Incidence Rates . . . . . . . . . . . . . 2-10

2.5.4 Total Recordable Case Incidence Rates . . . . . . . . . . . . . . 2-11

2.5.5 Occupational Injuries/llinesses By Type . . . . . . . . . . . . 2-12

2.5.6 Occupational Injuries/llInesses By Body Group Injured . . . . . . . . . . 2-13

2.5.7 Occupational Injuries/llinesses By Cause . . . . . . . . . . . . . . 2-14

2.5.8 Occupational Injuries/llinesses By Job Type . . . . . . . . . . 2 2-15

2.5.9 Occupational Injuries/Illnesses By Facility ............. 2-16

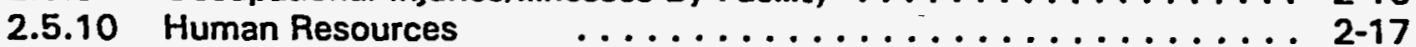

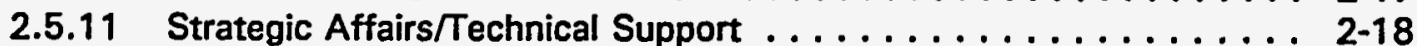

2.5.12 Transition Projects $\ldots \ldots \ldots \ldots \ldots \ldots \ldots \ldots \ldots \ldots . \ldots \ldots$ 2-19

2.5.13 Spent Nuclear Fuel Project ... . . . . . . . . . . . . . . . 2-20

2.5.14 Emergency, Safety, Quality Services ................. 2-21

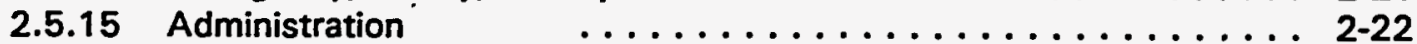

2.5.16 Boeing Computer Services, Richland ............... 2-23

2.5.17 Tank Waste Remediation Systems . . . . . . . . . . . . . 2-24 
WHC-SP-0564-37

\section{TABLE OF CONTENTS (Continued)}

2.5.18 Projected Site Services . . . . . . . . . . . . . . . . 2-25

2.5.19 Solid Waste Disposal $\ldots \ldots \ldots \ldots \ldots \ldots \ldots \ldots \ldots$ 2-26

2.5.20 ICF Kaiser Hanford Company . . . . . . . . . . . . . . . . . . . . 2-27

2.5.21 Recordable Government Motor Vehicle Accidents . . . . . . . . . . 2-28

3.0 RADIOLOGICAL SAFETY $\ldots \ldots \ldots \ldots \ldots \ldots \ldots \ldots \ldots \ldots \ldots \ldots \ldots \ldots \ldots, 3-1$

3.1 RADIOLOGICAL CONTROL PROGRAM PERFORMANCE $\ldots \ldots \ldots \ldots \ldots \ldots$ 3-1

3.1.1 Key Performance Trends. . . . . . . . . . . . . . . . 3-1

3.1.2 Program Accomplishments $\ldots \ldots \ldots \ldots \ldots \ldots \ldots \ldots \ldots \ldots$ 3-1

3.1.3 Program Status $\quad \ldots \ldots \ldots \ldots \ldots \ldots \ldots \ldots \ldots \ldots \ldots . \ldots \ldots$ 3-2

3.1.4 Schedule (DOE-HO/FO/RL) Status $\ldots \ldots \ldots \ldots \ldots \ldots \ldots \ldots$ 3-2

3.1.5 Key Program Issues . . . . . . . . . . . . . . . . 3-2

3.1.6 Health and Safety Statistics $\ldots \ldots \ldots \ldots \ldots \ldots \ldots \ldots \ldots$ 3-2

3.2 EXTERNAL DOSIMETRY ..................... 3-3

3.2.1 Occupational Collective Dose ................. 3-3

3.2.1.1 Cumulative Annual Occupational Collective Dose ..... 3-3

3.2.1.2 Individual Radiation Dose ............... 3-3

3.2 .2 High Whole Body Dose Evaluation $\ldots \ldots \ldots \ldots \ldots \ldots \ldots . \ldots . \ldots . \ldots$

3.2 .3 High Neutron Dose $\ldots \ldots \ldots \ldots \ldots \ldots \ldots \ldots \ldots \ldots . \ldots \ldots$

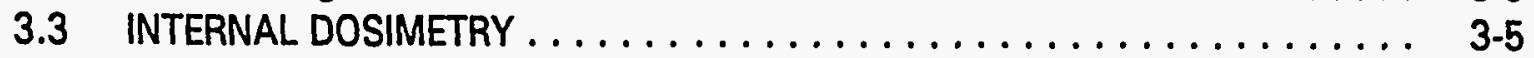

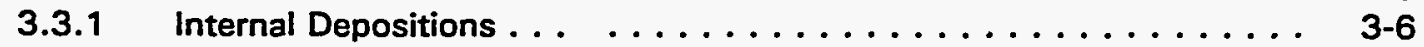

3.3.2 Internal Dose Incident Follow-Up . . . . . . . . . . . . 3-6

3.3.3 Update of Fourth Quarter CY 1994 Incident Follow-Up . . . . . . . 3-6

3.3.4 Direct and (in vivo) Indirect (in vitro) Measurements . . . . . . . . . . 3-7

3.4 SKIN AND CLOTHING CONTAMINATIONS $\ldots \ldots \ldots \ldots \ldots \ldots \ldots \ldots$

3.4.1 Cumulative CY 1995 Skin Contaminations and Clothing Contaminations 3-9

3.4.2 Significant Skin Contaminations ................ 3-10

3.4.3 Facial Contaminations . . . . . . . . . . . . . . . 3-10

3.4.4 Skin and Clothing Contamination Report Review ............ 3-11

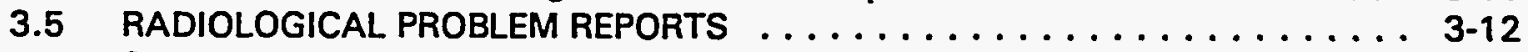

3.5.1 Radiological Problem Reports Issued $\ldots \ldots \ldots \ldots \ldots \ldots \ldots$. . . . . . . 12

3.5.1.1 Number of RPRs Written: 4th Quarter 1992 - 1st Quarter 19953

3.5.1.2 Factors Influencing the Number of RPRs Written . . . . 3 3-13

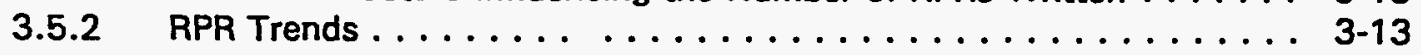

3.5.2.1 RPRs by Priority Planning Grid . . . . . . . . . . 3-13

3.5.2.2 RPRs by Type and Cause ............... 3-14

3.5.2.3 Contamination Events . . . . . . . . . . . 3-15

3.5.3 Average Time to Close an RPR .................. 3-16

3.5.3.1 Open RPRs $\ldots \ldots \ldots \ldots \ldots \ldots \ldots \ldots \ldots \ldots \ldots \ldots$ 3-16

$3.5 .3 .2 \quad$ RPR Average Days Open $\ldots \ldots \ldots \ldots \ldots \ldots \ldots \ldots \ldots \ldots \ldots \ldots$
$\ldots \ldots \ldots \ldots \ldots \ldots$

REFERENCES $\ldots \ldots \ldots \ldots \ldots \ldots \ldots \ldots \ldots \ldots \ldots \ldots \ldots \ldots \ldots \ldots \ldots \ldots \ldots$

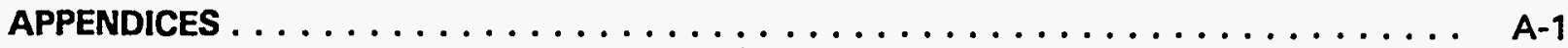

GLOSSARY $\ldots \ldots \ldots \ldots \ldots \ldots \ldots \ldots \ldots \ldots \ldots \ldots \ldots \ldots \ldots \ldots \ldots \ldots$ 


\section{LIST OF FIGURES}

1-3-1 Airborne Radioactivity Areas $\ldots \ldots \ldots \ldots \ldots \ldots \ldots \ldots \ldots \ldots \ldots \ldots \ldots$ 1-4

1-3-2 Indoor Contaminated Areas . . . . . . . . . . . . . . . . . 1-5

1-3-3 Outdoor Contaminated Areas . . . . . . . . . . . . . . . . . 1-5

1-3-4 Contaminated Area Reduction by Facility Group - FY 1995 . . . . . . . . . . . . . 1-6

1-3-5 Contaminated Area: Other Area Reductions . . . . . . . . . . . . 1-7

2-1 Cumulative Trauma Disorder Case History - Total Recordable

Cases/Lost Workday Cases . . . . . . . . . . . . . . . . . . . . 2-3

2-2 Cumulative Trauma Disorder Case History - Lost/Restricted Workdays . . . . . . 2-3

2-3 Back/Neck Strain Case History - Total Recordable Cases/Lost Workday Cases . . . 2-4

2-4 Back/Neck Strain Case History - Lost/Restricted Workdays . . . . . . . . . . . . 2-4

2-5 All Strain/Sprain Case History - Total Recordable Cases/Lost Workday Cases . . . . 2-5

2-6 All Strain/Sprain Case History - Lost/Restricted Workdays . . . . . . . . . . . 2-5

2-7 WHC Lost/Restricted Workday Case Incidence Rate . . . . . . . . . . . . 2-9

2-8 WHC Lost/Restricted Workday Case Monthly Incidence Rates CY 1990-CYTD 1995 - 3 Standard Deviations . . . . . . . . . . . . . . . . 2-9

2-9 WHC Lost/Restricted Workday Incidence Rates . . . . . . . . . . . . . . 2-10

2-10 WHC Lost/Restricted Workday Monthly Incidence Rates

CY 1990-CYTD 1995 - 3 Standard Deviations . . . . . . . . . . . . . . . . . . . 2-10

2-11 WHC Total Recordable Case Incidence Rate ... . . . . . . . . . . . 2-11

2-12 WHC Total Recordable Case Monthly Incidence Rates -

CY 1990-CYTD 1995 - 3 Standard Deviations . . . . . . . . . . . . . . . . . 2-11

2-13 First Aid Only By Type of Injury/lliness . . . . . . . . . . . . . . 2-12

2-14 Total Recordable Injuries/lliness By Type . . . . . . . . . . . . . . . . . . 2-12

2-15 Lost/Restricted Workday Cases By Type of Injury/lliness . . . . . . . . . . . . . . 2-12

2-16 First Aid Only By Body Group Injured . . . . . . . . . . . . . . . . 2-13

2-17 Total Recordable Injuries/llinesses By Body Group Injured . . . . . . . . . . 2-13

2-18 Lost/Restricted Workday Cases By Body Group Injured . . . . . . . . . . . . . . . 2-13

2-19 First Aid Only By Cause . . . . . . . . . . . . . . . . . . . 2-14

2-20 Total Recordable Injuries/llinesses By Cause . . . . . . . . . . . . . . . . . . 2-14

2-21 Lost/Restricted Workday Cases By Cause . . . . . . . . . . . . . . . . . . 2-14

2-22 First Aid Only By Job Type . . . . . . . . . . . . . . . . . . 2-15

2-23 Total Recordable Injuries/llinesses By Job Type . . . . . . . . . . . . . . . . . 2-15

2-24 Lost/Restricted. Workday Cases By Job Type . . . . . . . . . . . . . . . . . . 2-15

2-25 First Aid Only By Facility . . . . . . . . . . . . . . . . . . . . . 2-16

2-26 Total Recordable Injuries/llinesses By Facility . . . . . . . . . . . . . . 2-16

2-27 Lost/Restricted Workday Cases By Facility . . . . . . . . . . . . . . . . . . . 2-16 


\section{LIST OF FIGURES (Continued)}

3-2-1 Monthly, Quarterly and Annual Exchange Dosimeter Results CY $1995 \ldots$. . . . . 3-3

3-2-2 Monthly Badged Employee Average Cumulative Radiation Dose . . . . . . . . . . 3-4

3-2-3 Whole Body Dose Distribution - Cumulative .................. 3-4

3-2-4 Highest Neutron Dose $\ldots \ldots \ldots \ldots \ldots \ldots \ldots \ldots \ldots \ldots \ldots \ldots \ldots \ldots$ 3-5

3-3-1 Indirect (In Vitro) Measurements $\ldots \ldots \ldots \ldots \ldots \ldots \ldots \ldots \ldots \ldots$

3-3-2 Direct (In Vivo) Measurements $\ldots \ldots \ldots \ldots \ldots \ldots \ldots \ldots \ldots \ldots \ldots$

3-4-1 1995 Skin and Clothing Contaminations $\ldots \ldots \ldots \ldots \ldots \ldots \ldots \ldots \ldots$

3-4-2 Facial Contaminations . . . . . . . . . . . . . . . . . . 3-10

3-4-3 Personnel Contaminatin by Cause . . . . . . . . . . . . . . . . 3-11

3-5-1 Cumulative Radiological Problem Reports Issued . . . . . . . . . . . . . 3-12

3-5-2 Facilities Issued RPRs - First Quarter Comparison . . . . . . . . . . . 3-13

3-5-3 RPRs by Cause. . . . . . . . . . . . . . . . . . . . 3-15

3-6-1 Dose Assessments Performed for Lost or Damaged Dosimeters . . . . . . . . 3-17 


\section{LIST OF TABLES}

1-3-1 Airborne Radioactivity Areas by Facility Group . . . . . . . . . . . . . . . 1-4

1-3-2 Indoor contamination Areas and High-Contamination Areas $\ldots \ldots \ldots \ldots$

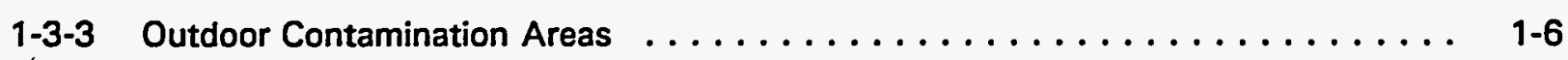

1-7-1 ALARA Council Members ......................... 1-10

2-1 Ergonomic Workstation Evaluations $\ldots \ldots \ldots \ldots \ldots \ldots \ldots \ldots \ldots$

2-2 WHC Occupational Injury/lllness Statistics Comparison $\ldots \ldots \ldots \ldots \ldots \ldots$

2-3 Human Resources - Occupational Injury/lllness Statistics Comparison . . . . . 2-17

2-4 Human Resources - Occupational Injuries/llinesses By Type . . . . . . . . . 2-17

2-5 Strategic Affairs/Technical Support - Occupational Injury/lliness

Statistics Comparison . . . . . . . . . . . . . . . . . . . 2-18

2-6 Strategic Affairs/Technical Support - Occupational Injuries/lllnesses By Type . . . 2-18

2-7 Transition Projects - Occupational Injury/lllness Statistics Comparison . . . . . 2-19

2-8 Transition Projects - Occupational Injuries/lllnesses By Type . . . . . . . . . . . 2-20

2-9 Spent Nuclear Fuel - Occupational Injury/lliness Statistics Comparison . . . . . . 2-20

2-10 Spent Nuclear Fuel - Occupational Injuries/lilnesses By Type . . . . . . . . . . . 2-21

2-11 Emergency, Safety, Quality Services- Occupational Injury/lliness Statistics Comparison - . . . . . . . . . . . . . . . 2-21

2-12 Emergency, Safety, Quality Services - Occupational Injury/lliness By Type . . . . . 2-22

2-13 Administration - Occupational Injury/lliness Statistics Comparison . . . . . . 2-22

2-14 Administration - Occupational Injuries/lllnesses By Type . . . . . . . . . . . 2-23

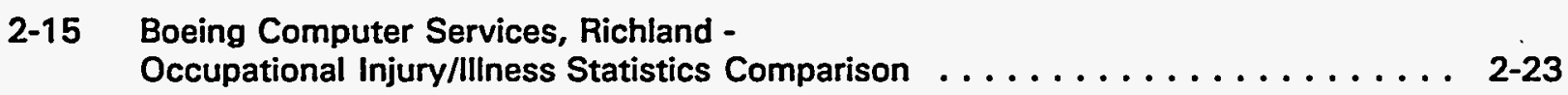

2-16 Boeing Computer Services, Richland - Occupational Injuries/llinesses By Type _. . 2-24

2-17 Tank Waste Remediation Systems - Occupational Injury/llness Statistics Comparison2-24

2-18 Tank Waste Remediation Systems - Occupational Injuries/lllnesses By Type . . . . 2-25

2-19 Projected Site Services - Occupational Injury/lliness Statistics Comparison . . . . 2-25

2-20 Projected Site Services - Occupational Injuries/llinesses By Type . . . . . . . . . . 2-26

2-21 Solid Waste Disposal - Occupational Injury/lliness Statistics Comparison . . . . . 2-26

2-22 Solid Waste Disposal - Occupational Injuries/lllnesses By Type . . . . . . . . . . 2-27

2-23 Recordable Vehicle Accidents by Organization . . . . . . . . . . . . . 2-28

2-24 Recordable Vehicle Accidents by Cause of Accident . . . . . . . . . . . 2-28

3-2-1 Highest Whole-Body-Dose Employees . . . . . . . . . . . . . . . . 3-5 
WHC-SP-0564-37

This page intentionally left blank.

xiv 


\subsection{ALARA}

As Low As Reasonably Achievable (ALARA) is an approach to radiation protection to manage and control both individual and collective exposures to the work force and the general public and releases of radioactive material to the environment. This is to be accomplished while taking into account social, technical, economic, practical, and public policy considerations. It is important to remember that ALARA is not a dose limit, but rather it is a process that has an objective of attaining dose levels as far below the applicable limits as practicable.

Management support and commitment to reducing individual and collective exposures and controlling radioactive contamination are critical elements in ensuring a successful ALARA Program. However, this is only the first step in keeping personnel exposure ALARA. The success of the ALARA program is dependant on its acceptance, support, and implementation by all personnel involved in radiological activities.

\subsection{WESTINGHOUSE HANFORD COMPANY (WHC) ALARA GOALS}

During the first quarter of calendar year (CY) 1995, there has been an increasing amount of attention placed on the ALARA performance goals process by facility/organizational ALARA Committees, the ALARA Council, and the ALARA/Contamination Control Improvement Project (CCIP) Program Office. This is illustrated by the percentage of goals completed on or ahead of schedule by the facilities/organizations. It is further evidenced by the completion of $100 \%$ of the sitewide ALARA performance goals scheduled for completion by the ALARA Council and ALARA Program Office during this reporting period.

\subsubsection{Sitewide ALARA Performance Goals}

During the first quarter of CY 1995, four of the WHC sitewide ALARA performance goals were completed on or ahead of schedule. One of the completed goals related to reduction of radiological areas at WHC-managed facilities. Due to anticipated resource reductions and increased scope of work several facilities escalated their reduction schedule. This allowed the ALARA goal to be completed and exceeded ahead of schedule. For detailed information relating to the completion of sitewide ALARA performance goals, refer to Appendix A-1.

\subsubsection{Facility/Organization ALARA Goal Performance}

Progress on the implementation of the ALARA Program is evidenced in part by the development and achievement of ALARA performance goals by the facility/organization ALARA Committees. The CY 1995 facility-specific goals have been established to effectively implement exposure reduction activities as well as to provide the incentive to implement ALARA. Facilityspecific goals also provide a method to measure the achievement of ALARA programs.

It is important to note that the facility-specific ALARA goals are not the only method utilized to measure the program effectiveness. More detailed information relating to the field implementation of ALARA principles can be found in Section 1.2 of this report. 
WHC-SP-0564-37

\subsection{ALARA/CCIP PROGRAM IMPLEMENTATION, PROGRESS, AND ACHIEVEMENTS}

The ALARA/CCIP Program Office believes it is important to promote the contributions and accomplishments of the ALARA Program by communicating the progress and achievements. The following is a list of some of those contributions and accomplishments achieved in the first quarter of CY 1995.

- A draft of the WHC ALARA Program Manual revision was issued for senior management review and comment. The "essential elements of an acceptable occupational ALARA Program" as defined in the Occupational ALARA Program Implementation Guide, G-10 CFR 835, B2-Revision 1, have been incorporated in the manual;

- A representative of the ALARA/CCIP Program Office provided an ALARA overview training module to the "Health Physics for Department of Energy (DOE) Facilitators" class;

- A representative of the ALARA/CCIP Program Office is continuing to assist a group working to improve the Conduct of Operations at 222-S Laboratories. Weekly meetings are being held to identify areas of concern and appropriate solutions;

- An ALARA training overview session was held with representatives from DOE-Richland Field Office (RL);

- A presentation at the Operations Excellence Council provided information on a proven procedure to get more interaction in prejob briefings;

- Representatives of the ALARA/CCIP Program Office provided information and assistance in

- Changing out fire suppression nozzles in Plutonium Finishing Plant fume hoods without installing greenhouses;

- Demonstrating to ICF Kaiser Hanford Company (ICF KH) that, if a glovebag is used instead of greenhouses, a job could be worked at the same time that sludge stabilization was in progress, and outlined work steps necessary to weld without a glove bag;

- Identifying the proper radiological controls for replacement of radioactive liquid drain piping at PFP, the assessment of radiological controls for cutting out an elbow in the radioactive liquid drain system, and demonstrated how to set up ventilation and get make-up air into containments;

- Radiological controls assessments for removal of piping, components, wiring, ducting, etc., in Building 232-Z Scrubber Room were conducted. This included demonstrating how to modify containments, use cameras, set up ventilation, pad the containment floor, reduce mixed waste, increase lighting, and use stripable latex decontamination paint;

- Sharing of the lessons learned from the use of remote monitoring equipment to reduce radiation exposure;

- Supplied 12 cameras and 3 TV monitors to Scientific Engineering for use at K Basin; 
- Coordinated the procurement of 8 pieces of "free" steel plate owned by ICF KH for Building 309 to shield highly radioactive demineralizers.

- The ALARA/CCIP Program Office provided Post ALARA Review (PAR) training at B Plant. Each of the ALARA Committees were given an opportunity to send personnel to this training or have similar training conducted at their facility.

- A presentation and demonstration of a new technology developed by Timberline Enterprises was sponsored by the ALARA Program Office. The product demonstration of a newly designed contamination fixative was attended by over 30 WHC employees.

\subsection{CONTAMINATION CONTROL IMPROVEMENT PROJECT}

The CCIP encourages reduction of radioactive surface contamination in operating areas and the environment of the Hanford Site. Reducing the number of contaminated areas and the severity of contamination will reduce the risk of skin contaminations and internal depositions, minimize personnel exposure, increase site productivity, and improve protection of the environment.

During the fourth quarter of CY 1994, there was an overhaul of the CCIP database driven by the new posting definitions found in the Hanford Site Radiological Control Manual (HSRCM1). Currently, for CCIP purposes, the postings are grouped as follows: Airborne radioactivity areas (ARA); total contamination areas (CA) which include high CA, CA and soil CA ; total radiation areas (RA) which include very high RA, high RA, and RA; and other radiological areas which includes radiological buffer area, fixed contamination area, radioactive material area (RMA), and underground radioactive materials. The result of these changes is there is no continuity between the fourth quarter and previous ones'. Therefore, the only comparison in this section will be between the current quarter (first of CY 1995) and the previous one.

The CCIP tracks CAs, as well as the categorization of areas controlled for radiological reasons and the quantification of said areas. It also tracks, separately from CAs, ARAs. The project identifies, tracks, and encourages the reduction of radioactive surface contamination and the number of other radiologically controlled areas. It addresses ARAs in indoor areas and CAs and other areas in indoor and outdoor operating areas.

\subsubsection{Airborne Radioactivity Areas}

Airborne Radioactivity Areas are tracked separately from CAs because of the inherent increased risk to the occupational worker. Generally, ARAs are not as easy to decrease as surface contaminated areas (SCA) because they are related to the process and are engineered areas. They are decreased as the underlying process is changed or discontinued and the area is decontaminated (Figure 1-3-1).

The number (as well as the total size) of ARAs established by facility group for the first quarter of 1995 is listed in Table 1-3-1. Please note that the number of ARAs may be arbitrary, in that one facility may elect to group all their ARAs together (for CCIP reporting purposes), while another may report each individual ARA separately. 
WHC-SP-0564-37

Figure 1-3-1. Airborne Radioactivity Areas

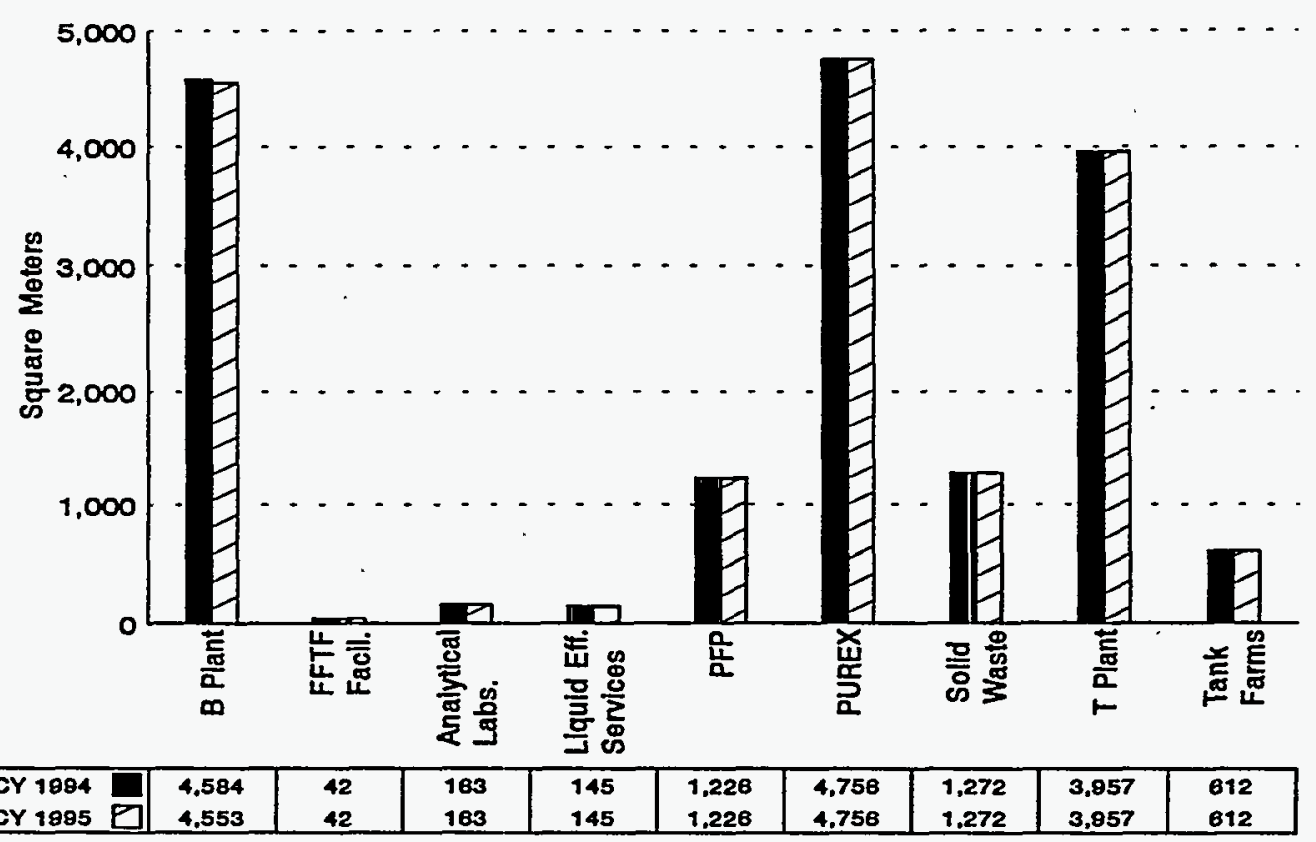

Table 1-3-1. Airborne Radioactivity Areas by Facility Group

\begin{tabular}{|l|c|c|c||l|l|l|l|}
\hline \multicolumn{1}{|c|}{ Facility } & $\begin{array}{c}\text { No. of } \\
\text { ARAs }\end{array}$ & $\begin{array}{c}\text { ARAs in } \\
\text { Sq. Meters }\end{array}$ & $\begin{array}{c}\text { ARAs in } \\
\text { Sq. Feet }\end{array}$ & Facility & $\begin{array}{c}\text { No. of } \\
\text { ARAs }\end{array}$ & $\begin{array}{c}\text { ARAs in } \\
\text { Sq. } \\
\text { Meters }\end{array}$ & $\begin{array}{c}\text { ARAs in } \\
\text { Sq. Feet }\end{array}$ \\
\hline \hline B Plant & 22 & 4,553 & 49,013 & Solid Waste & 1 & 1,272 & 13,689 \\
\hline $\begin{array}{l}\text { Fast Flux Test } \\
\text { Facility (FFTF) }\end{array}$ & 1 & 42 & 450 & T Plant & 7 & 3,957 & 42,595 \\
\hline $\begin{array}{l}\text { Analytical } \\
\text { Laboratories }\end{array}$ & 6 & 163 & 1,758 & Tank Farms & 11 & 612 & 6,586 \\
\hline $\begin{array}{l}\text { Plutonium Finishing } \\
\text { Plant (PFP) }\end{array}$ & 5 & 1,226 & 13,194 & Liquid Effluent \\
Services & 5 & 145 & 1,560 \\
\hline PUREX & 20 & 4,756 & 51,192 & Total & 76 & 16,726 & 180,037 \\
\hline
\end{tabular}

\subsubsection{Indoor and Outdoor $\mathrm{CA}$}

Most facilities have been reducing the amount of posted CAs indoor. During the first quarter of CY 1995, there were reported reductions in indoor CA of 80 square meters (855 square feet) and in outdoor CA of 11 hectares (26 acres). Also, during this period, the $\mathrm{UO}_{3}$ facility was transferred from WHC to BHI, which included approximately 1,600 square meters $(17,000$ square feet) of indoor CA and 0.4 hectares (1.1 acres) of outdoor CA. There were increases reported during the same period of approximately 102 square meters $(1,100$ square feet) in indoor CA and of 190 square meters $(2,000$ square feet) in outdoor $\mathrm{CA}$. 
Overall, the amount of indoor posted CA has been decreasing (Figure 1-3-2). Outdoor areas are separated into two categories for tracking purposes - areas associated with "operating" facilities and those that are not (Figure 1-3-3).
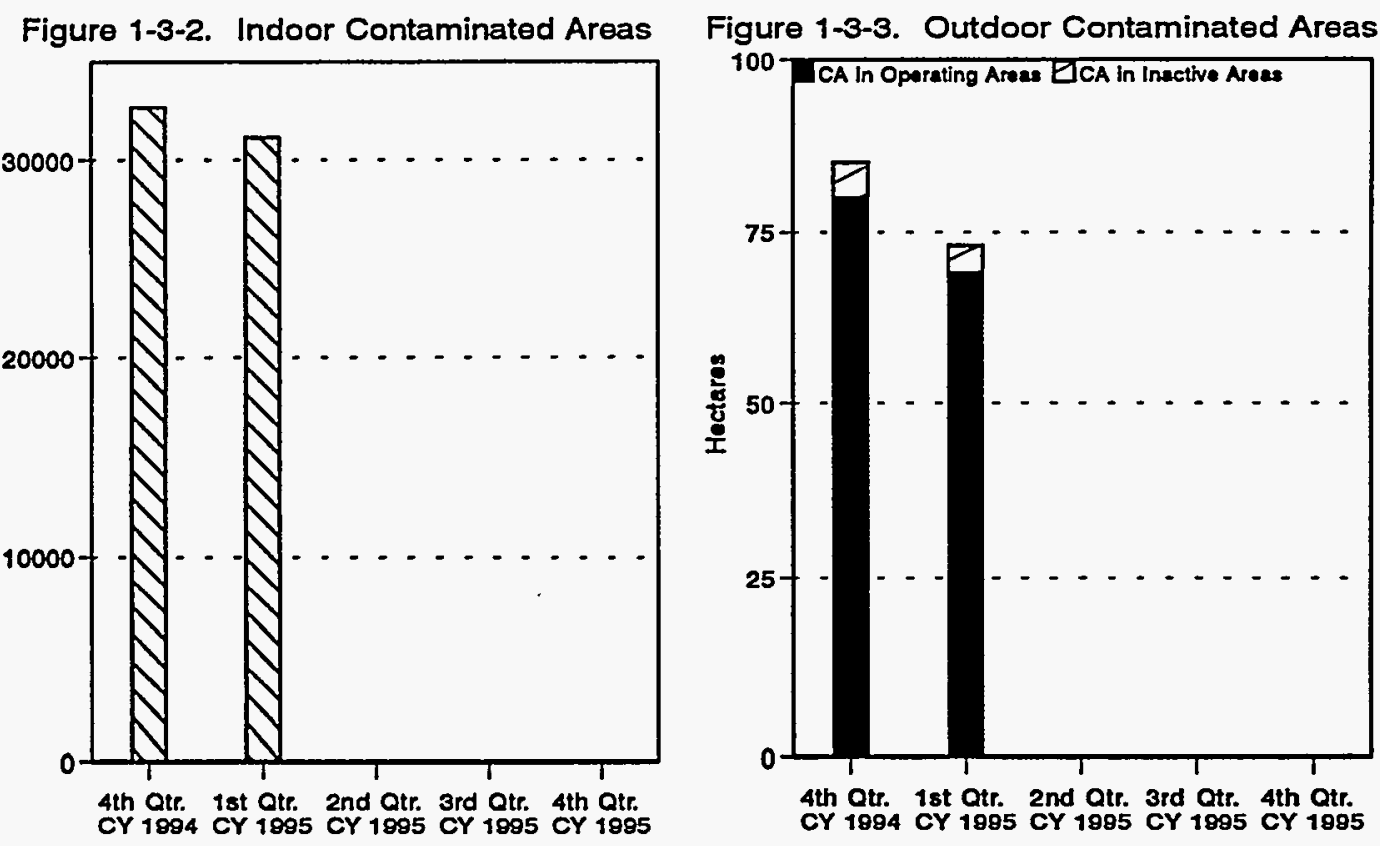

The number (as well as the total size) of high contamination areas (HCA) and CAs indoors, as established by facility group for the first quarter of CY 1995, is listed in Table 1-3-2 and for outdoor CAs (there being no outdoor HCAs) in Table 1-3-3. Please note that the number of HCAs and CAs may be arbitrary, in that one facility may elect to group all their CAs together (for CCIP reporting. purposes), while another may report each individual CA separately.

Table 1-3-2 Indoor Contamination Areas and High-Contamination Areas

\begin{tabular}{|l|r|r|r|r|r|r|}
\hline \multicolumn{1}{|c|}{ Indoor Areas } & $\begin{array}{c}\text { No. } \\
\text { HCAs }\end{array}$ & $\begin{array}{c}\text { Area in } \\
\text { Meters }\end{array}$ & $\begin{array}{c}\text { Area in } \\
\text { Square Feet }\end{array}$ & $\begin{array}{c}\text { No. } \\
\text { CAs }\end{array}$ & $\begin{array}{c}\text { Area in } \\
\text { Meters }\end{array}$ & $\begin{array}{c}\text { Area in } \\
\text { Square Feet }\end{array}$ \\
\hline \hline 300 Area Facilities & 0 & 0 & 0 & 19 & 2,485 & 26,748 \\
\hline B Plant & 2 & 3,702 & 39,850 & 55 & 1,410 & 15,177 \\
\hline FFTF Facilities & 1 & 42 & 450 & 3 & 230 & 2,476 \\
\hline K Basins & 0 & 0 & 0 & 5 & 2,925 & 31,484 \\
\hline Analytical Laboratories & 4 & 154 & 1,654 & 53 & 2,169 & 23,349 \\
\hline Liquid Effluent Services & 0 & 0 & 0 & 4 & 488 & 5,252 \\
\hline PFP & 1 & 141 & 1,514 & 14 & 4,351 & 46,838 \\
\hline PUREX & 11 & 4,145 & 44,615 & 37 & 3,896 & 41,934 \\
\hline Support Services & 0 & 0 & 0 & 6 & 275 & 2,964 \\
\hline T Plant & 4 & 2,624 & 28,246 & 10 & 685 & 7,374 \\
\hline Tank Farms & 4 & 113 & 1,218 & 14 & 1,279 & 13,771 \\
\hline Total & 27 & 10,920 & 117,547 & 220 & 20,194 & 217,367 \\
\hline
\end{tabular}


Table 1-3-3. Outdoor Contamination Areas

\begin{tabular}{|l|r|r|r|}
\hline \multicolumn{1}{|c|}{ Outdoor Areas } & $\begin{array}{c}\text { No. } \\
\text { CAs }\end{array}$ & \multicolumn{1}{c|}{$\begin{array}{c}\text { Area in } \\
\text { Hectares }\end{array}$} & $\begin{array}{c}\text { Area in } \\
\text { Acres }\end{array}$ \\
\hline \hline 300 Area Facilities & 2 & 2.2 & 5.5 \\
\hline B Plant & 10 & 4.3 & 10.6 \\
\hline Environmental & 9 & 1.9 & 4.8 \\
\hline K Basins & 1 & 0.3 & 0.7 \\
\hline PUREX & 10 & 6.8 & 16.7 \\
\hline Solid Waste & 4 & 5.4 & 13.5 \\
\hline Support Services & 3 & 0.2 & 0.5 \\
\hline Surplus Facilities & 2 & 9.4 & 23.1 \\
\hline T Plant & 9 & 1.0 & 2.4 \\
\hline Tank Farms & 41 & 44.2 & 109.2 \\
\hline \hline Total & 91 & 75.7 & 186.9 \\
\hline
\end{tabular}

\subsubsection{CA Reduction - Indoor and Outdoor Areas}

The CCIP tracks reduction efforts separately from the overall total posted areas and tracks and trends the total area reduced by facility on a quarterly basis. During the first quarter of 1995, a total of approximately 107,088 square meters $(1,152,691$ square feet) was released from CA posting. Specific reductions by facility per quarter (in square meters) are found in Figure 1-3-4.

Figure 1-3-4. CA Reciuction by Facility Group - FY 1995

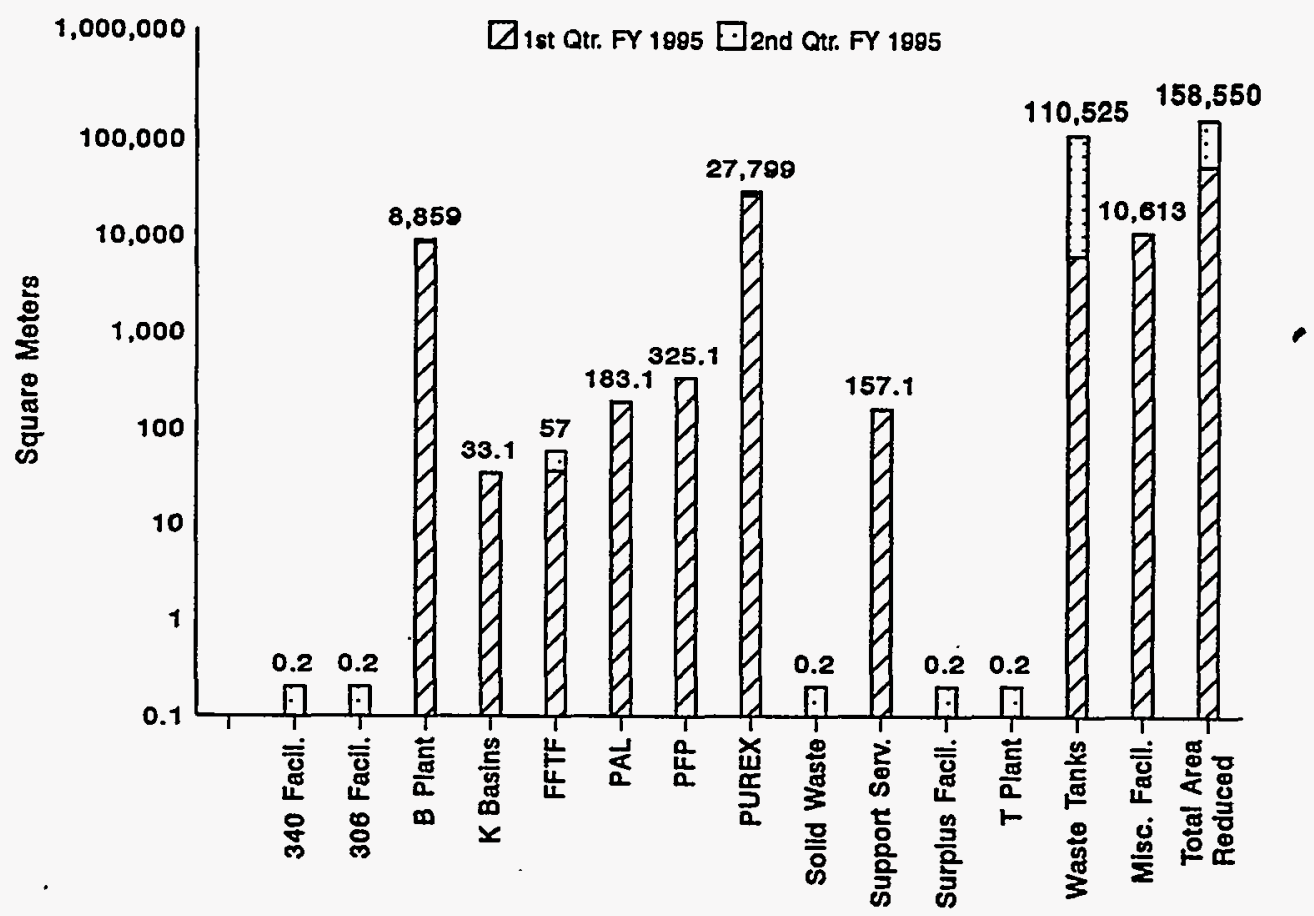


The CCIP also tracks reductions in areas posted less than CA (e.g. RAs, RMAs, etc.). During the same time period, a total of approximately 179,135 square meters $(1,928,196$ square feet) of "other" area was downposted. Specific reductions by facility per quarter (in square meters) are found in Figure 1-3-5.

Figure 1-3-5. CA Other Area Reductions - FY 1995

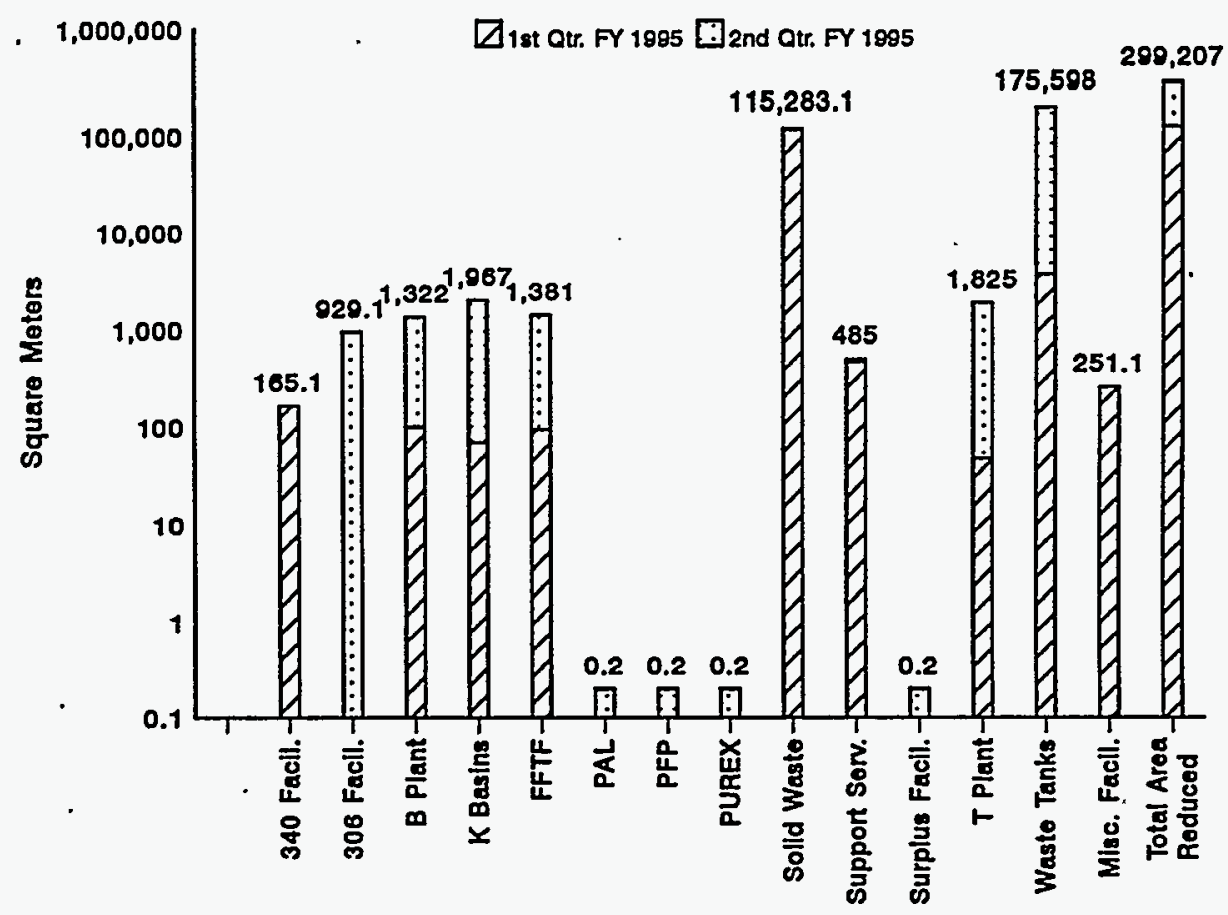

\subsection{ALARA PROGRAM LESSONS LEARNED THROUGH POST ALARA REVIEWS}

In February 1994, the Search Hanford Accessible Records Electronically (SHARE) database was placed online. This database was designed to provide an intelligent information retrieval system that allows users to create query topics to meet their individual needs. The ALARA/CCIP Program Office currently utilizes this database to redeploy ALARA Protective Measures (APM) and lessons learned from work performed onsite. The SHARE database is now available for WHC personnel involved in the process of designing, performing, and/or managing work projects. SHARE makes completed copies of PARs available electronically for review, retrieval, and use by planners, personsin-charge (PIC), engineers, ALARA personnel, etc., in the creation of work packages and in performing prejob briefings.

There is some concern regarding the timely completion of the PAR process. Management is reminded that the PAR process is a vital tool in helping to prevent.complacency, reduce personnel exposure, monitor job performance, and identifying lessons learned for incorporation into similar job packages. The lessons learned help to evaluate the effectiveness of the exposure controls that were implemented, and reduce future exposures by applying these experiences. There is some early evidence that the acceptance and ownership of the PAR process is beginning to be significantly enhanced. The ALARA/CCIP Program Office compiled results from some of the PARs completed during the first quarter for this report. 
- PUREX, during the replacement of a plexiglass port, identified the need to have larger sampling bottles. There was concern regarding the amount of prejob planning that went into this job. The hood port scheduled to be installed was not the same as the Hanford standards identified.

- Fast Flux Test Facility (FFTF) found that they could reduce the personnel exposure received from a rail car shipment by having the Health Physics Technician (HPT), scheduled to be on duty during the actual work evolution, sign the original via telephone conference instead of performing a second review and receiving additional exposure.

- PUREX determined that the use of plastic protective clothing may not have provided the best protection during a high-efficiency particulate air (HEPA) filter changeout. They determined that Gortex protective clothing would have provided better protection due to the increased tear resistance.

- PUREX identified the need to have all crafts involved in performing a job also be involved in planning the design of the containment.

- FFTF placed layers of plastic in the work zone during a HEPA filter installation. This was very effective in containing loose contamination and expediting cleanup after job completion.

- PUREX identified the need for a more thorough prejob briefing to include the prestaging of equipment from each craft.

- $\mathrm{K}$ Basins realized several lessons learned during the installation of barrier doors at $105 \mathrm{~K}$ East and West. The lessons learned included:

- Utilization of camera equipment to monitor the seating surface of the barrier door;

- Use of epoxy caused the adherence of contamination to the workers gloves - this was solved by increasing the frequency of glove changeouts and closer monitoring by HPTs;

- PICs and Radiological Control personnel helped enforce the use of "low dose standby areas" to reduce personnel exposure. Personnel not directly involved in the work were restricted from access to the area to reduce collective personnel exposure and increase workers performance.

Further information on completed PARs may be obtained from the ALARA/CCIP Program Office, by reviewing previous issues of this publication, or by electronically accessing the SHARE database.

\subsection{ALARA TRACKING AND MANAGIMENT SYSTEM}

In order to identify, track, and manage personnel exposure within the responsible facility/organization, the ALARA Tracking and Management System (ATAMS) was developed. The system assists the ALARA/CCIP Program Office and ALARA Committee chairpersons in tracking the exposure levels of personnel under their jurisdiction, and the investigation of any anomaly. The ATAMS has further served to heighten exposure awareness levels of personnel and, with each investigation performed, it encourages management to consider the ALARA approach to exposure. The system selects individual and organizational anomalies identified within the following set of parameters and criteria:

- The top one percent of the monthly/quarterly thermoluminescent dosimeters (TLD) processed; 
- Extrapolated exposures through year end that will exceed a WHC worker's administrative guideline level;

- Individuals with significantly higher whole body dose than peers within their craft;

- Individuals identified as having high finger ring doses versus deep dose;

- Unusual TLD results identified during this processing period (i.e., shallow less than deep exposure);

- Individuals identified as having high neutron dose.

Investigative reports are required to provide an explanation for the anomaly. The investigative reports include a description of the ALARA protective measures that were used, the job work scope being performed, and any resolutions to reduce the repeat of similar exposures.

Investigations of anomalies, completed during this quarter, reveal concentrated efforts to maintain radiation exposure in the workplace ALARA. Certain trends may be identified with a direct relationship to areas where exposure-producing operations and activities are occurring within WHCmanaged facilities. Although anomalies are noted, they result in exposures well below the administrative guidelines established by WHC.

Detailed information on completed investigations may be obtained by contacting the WHC ALARA/CCIP Program Office at 376-9035.

\subsection{ALARA TRAINING}

Effective and successful implementation of any ALARA Program requires knowledge and understanding of the ALARA concepts. Consequently, training of personnel in ALARA, safety, and radiation principles is one of the most important elements in any effective ALARA Program.

The majority of ALARA training at WHC is incorporated in other training packages as a basic theme that is reinforced throughout the training session. This reduces the number of ALARA-specific courses necessary and ensures that a consistent emphasis is placed on ALARA policy and philosophy.

During the first quarter, Technical Training conducted 728 training sessions that included the : ALARA theme throughout, with 3,617 students completing the training. Some of the subjects covered in these training sessions included: Criticality Safety, Job Control Systems, and Hazardous Waste Materials Handling, as well as Hanford General Employee Training. In addition, a specific emphasis is placed on classic ALARA (radiological) in all courses relating to radiological training.

Efforts to raise the ALARA awareness of Hanford employees has and will continue during CY 1995. Specialized ALARA training has been created to provide technical support personnel (engineers, schedulers, procedure writers) with the principles of ALARA, basic ALARA techniques, and exposure reduction techniques. This training is available through the Hanford Training Center. 


\subsection{ALARA POINTS-OF-CONTACT}

The ALARA Points-of-Contact listing identifies the current ALARA Committee Chairperson designated by division, department, or facility management to coordinate the administration of the individual facility ALARA Program. Support personnel representing engineering, health and safety, industrial safety, and pollution prevention are also listed in Table 1-7-1.

Table 1-7-1. ALARA Council Members

ALARA/CCIP PROGRAM OFFICE

Radiological Engineering \& ALARA Manager

ALARA/CCIP Program Coordinator

ALARA Program Senior Health Physicist

Contamination Control Improvement Project

FACILITY SPECIFIC ALARA COMMITTEES

B Plant/WESF

Facility Operations/PUREX

Facility Operations/Plutonium Finishing Plant

Fast Flux Test Facility

K-Basins Operations

Processing and Analytical Laboratories

Solid Waste Disposal/T-Plant

340 Facility

ORGANIZATIONAL ALARA COMMITTEES

Kaiser Operations

Liquid Effluent Services

Solid Waste Management

Tank Waste Remediation Systems
T. D. Merkling

O. D. Berglund

L. O. Waggoner

R. E. Elder

H. G. Oglesbee

S. L. Hathaway

D. E. Kammenzind

A. M. Ostby

R. H. Smith, Jr.

L. A. Nelsen

D. W. Humphrys, II

M. D. Nuzum

B. A. Watkins

J. W. DeLine
3-9412

6-9035

6-0818

$6-4187$

$2-0080$

$2-0382$

3-5608

3-2564

3-2506

6-0603

3-3143

3-5966

3-2471

2-3608

ALARA COUNCIL SUPPORT PERSONNEL

Corps of Engineers

E. C. Benson, Jr.

$6-2531$

M. J. Hartney

2-1711

D. D. Morrison

3-0635

D. W. Carlyle

$3-4222$

R. J. Thomas

6-4937

Dosimetry

D. L. Stanton

6-9635

T. J. Kelly

3-1707

Industrial Safety

D. S. Penfield

2-3291

Protective Clothing Committee

R. H. Shanks

3-2089

Pollution Prevention 
WHC-SP-0564-37

\subsection{INDUSTRIAL SAFETY AND HYGIENE}

\subsection{INTRODUCTION}

The purpose of the Industrial Safety and Hygiene section is to provide a perspective on overall performance by WHC and BCSR Richland, Inc. (BCSR) on the Hanford Site. Additionally, this section attempts to paint the overall picture of WHC industrial safety and industrial hygiene activities through narrative and statistical data that identifies and statuses goals and initiatives, program development, as well as standards and training courses anticipated or completed for use.

\subsection{ONGOING INDUSTRIAL SAFETY AND HEALTH INITIATIVES}

\subsubsection{Voluntary Protection Program (VPP) - Noteworthy Activities During the First Quarter}

At the beginning of the quarter, the President's Accident Prevention Council (PAPC) accepted the recommendations developed by the Transition Projects (TRP) for 1995 Safety Goals. They are:

1) Use Accident Prevention Councils (APC's) to conduct Safety Improvement Self-Evaluation (SISE's) by 3/31/95.

2) Establish a VPP subcommittee through the PAPC.

3) Conduct self-surveys at least twice during 1995.

4) Conduct the Hanford Site Safety and Health Exposition by 5/01/95.

5) Implement Safety Improvement Plans (SIP's) during 1995. Report progress through the APC's quarterly.

Goals number one and two were successfully completed during the first quarter.

Communication activities relating to the VPP expanded during the quarter. The VPP Subcommittee took on the task of developing a Communications Plan which all APC's can use to publicize VPP in an organized and consistent manner. Additionally, the Office of Industrial Safety Planning released a VPP informational pamphlet for use by all WHC/BCSR and ICF KH employees, and worked on organizing and preparing a VPP exhibit for the April Safety Expo.

The SISE exercises proved to be a valuable activity for each Division. Not only did management empower the workforce to evaluate the safety process, but the resultant data collected by employee teams was found to be useful in future safety improvement planning.

Tank Waste Remediation Systems (Tank Farms) and Transition Projects (B-Plant/WESF) had the opportunity to participate in the Westinghouse Electric Corporation (WEC) VPP evaluation in late January. This activity served as a "mini" VPP Onsite Review, and assisted these organizations, as well as Safety Programs, in preparation and planning for a future DOE-VPP formal review. 
Course development progressed in formalizing a Manager Safety Training course for 1995 . It is being designed to assist managers in being successful within the framework of the VPP.

The Office of Industrial Safety Planning continues the process of revising and editing the WHC/BCSR application for candidacy within the DOE-VPP. Efforts during the quarter concentrated on responding to comments and suggestions initiated by DOE/HQ EM-23 on the contents of the document. To provide outside assistance in this and other areas of VPP, WHC/BCSR applied for and received admission into the DOE-VPP Outreach Program. We have been paired with the Dow Chemical Company Texas Operations facility by the VPP Participant's Association, for future benchmarking. This Dow facility has been approved as an OSHA-VPP STAR site since 1982.

\subsubsection{Traffic Control}

The Goal: Reduce vehicle accident potential.

Outer area bus service was eliminated during the first quarter. The potential for added traffic load has been recognized by our traffic safety group, and assessments of impact are underway. Early indications are that traffic increases have been off-set by employees using van-pools and car pools, leaving roadway totals still below what they were a year ago.

\subsubsection{Electrical.Safety}

The Goal: Find and correct the root cause behind significant electrical events.

Interim actions which were applied to planning for electrical work have been passed to the Safety Standards group for consideration of inclusion into planned revisions of the Industrial Safety Manual. A joint ICF KH/WHC electrical task team is beginning to look at issues which, when resolved, will become a feature of our safety control for administering electrical work.

\subsubsection{Workstation Ergonomics}

The Goal: Promote ergonomic awareness by workstation evaluations and training.

Progress: The WHC Ergonomic standard is nearing completion. When implemented, it will allow more of our safety professionals to perform office ergonomic evaluations, by following a standardized approach. This additional involvement will help us to keep pace with a growing number of requests for preventative work station evaluations.

Industrial Hygiene Programs (IHP) launched it's ergonomic awareness initiative in March by publishing an information brochure. As a part of this initiative, IHP is conducting briefings site wide on "Office Ergonomic Overview," which can be scheduled via the "WHC Ergonomic Program on cc:mail. 
Table 2-1. Ergonomic Workstation Evaluations

\begin{tabular}{|c|c|c|c|}
\hline $\begin{array}{c}\text { Department/ } \\
\text { Company }\end{array}$ & $\begin{array}{c}\text { Group/Individual } \\
\text { Evaluation Number(s) } \\
\text { 3rd Qtr. 1994 }\end{array}$ & $\begin{array}{c}\text { Group/Individual } \\
\text { Evaluation Number(s) } \\
\text { 4th Qtr. 1994 }\end{array}$ & $\begin{array}{c}\text { Group/Individual } \\
\text { Evaluation Number(s) } \\
\text { 1st Qtr. 1995 }\end{array}$ \\
\hline \hline $01 x-$ President & 0 & 1 & 0 \\
\hline $1 x-$ TRP & 39 & 13 & 38 \\
\hline $2 x-$ SNF & 1 & 11 & 3 \\
\hline $3 x-$ ESQ & 3 & 4 & 4 \\
\hline $4 x-$ ADM & 17 & 5 & 25 \\
\hline $5 x-$ ICF KH & 2 & 0 & 12 \\
\hline $6 x-$ BCSR & 3 & 19 & 15 \\
\hline $7 x-$ TWR & 113 & 112 & 12 \\
\hline $8 x-$ WAE & 34 & 67 & 109 \\
\hline \hline Total & 212 & 232 & \\
\hline
\end{tabular}

Flguro 2-1. Cumulativo Trauma Disordor Caso History Total Rocordablo Casos/Lost Workday Cases

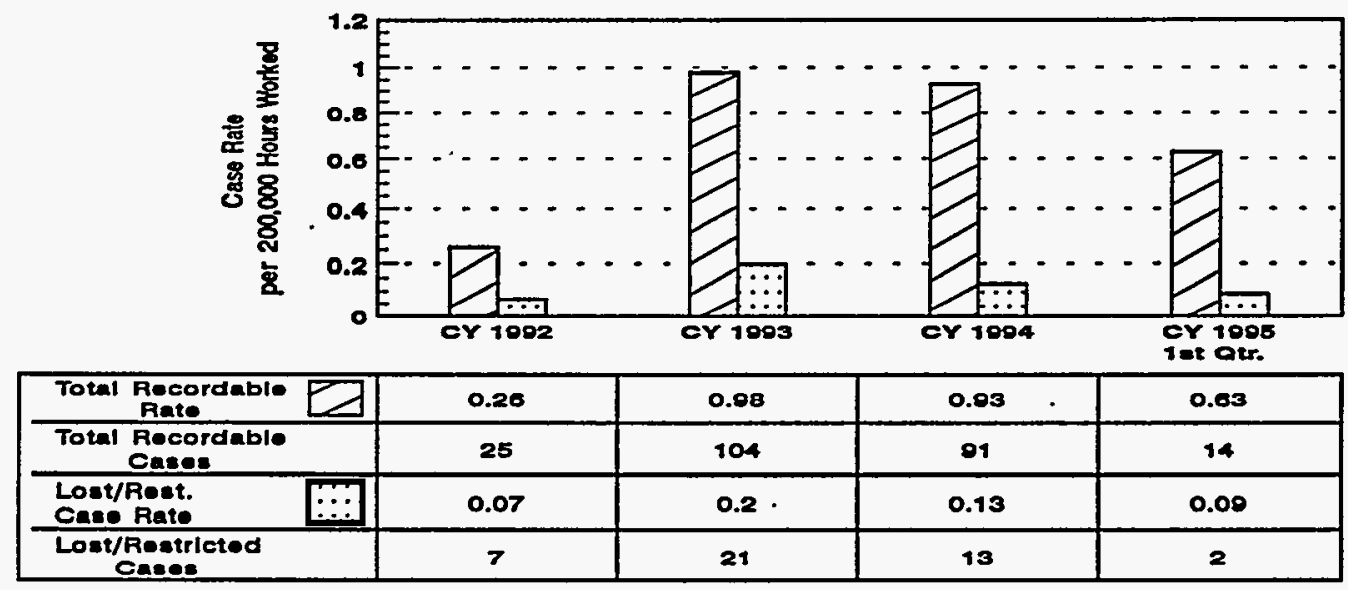

Figuro 2-2. Cumulativo Trauma Dlsordor Caso History Lost/Rostrictod Workdays

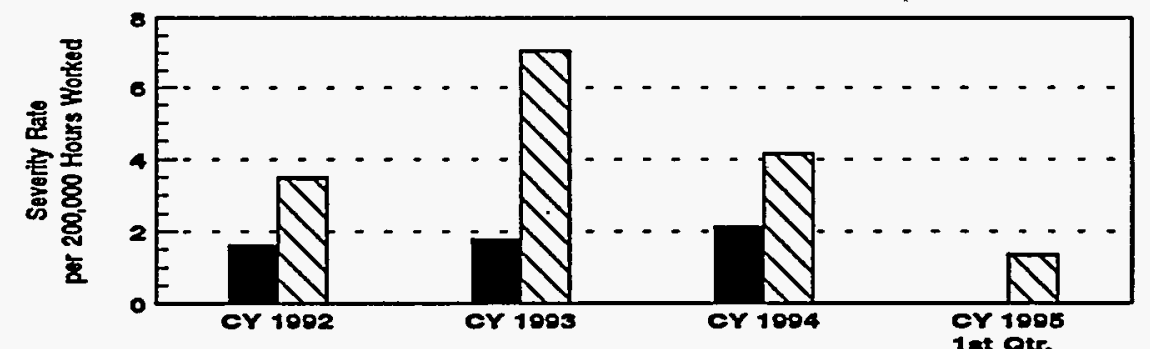

\begin{tabular}{|c|c|c|c|c|}
\hline $\begin{array}{c}\text { Workdays Away } \\
\text { Rate }\end{array}$ & 1.81 & 1.77 & 2.13 & 0 \\
\hline $\begin{array}{c}\text { No. of } \\
\text { Workdaye Away }\end{array}$ & 157 & 188 & 200 & 0 \\
\hline $\begin{array}{c}\text { Restrictod Days } \\
\text { Rate }\end{array}$ & 3.47 & 7.07 & 4.14 & 1.34 \\
\hline $\begin{array}{l}\text { No. of } \\
\text { Pastrlctod Daye }\end{array}$ & 338 & 751 & 407 & 30 \\
\hline
\end{tabular}




\subsubsection{Back Injury Reduction}

Concerted attention and elevation of awareness levels, combined with increased use of training, has helped to significantly reduce the severity of back strain cases (Figures 2-3 and 2-4).

This positive trend has continued through the first quarter, as reflected by the steady reduction of the lost/restricted workday case rates.

Figure 2-3. Back/Neck Strain Case History Total Recordable Cases/Lost Workday Cases

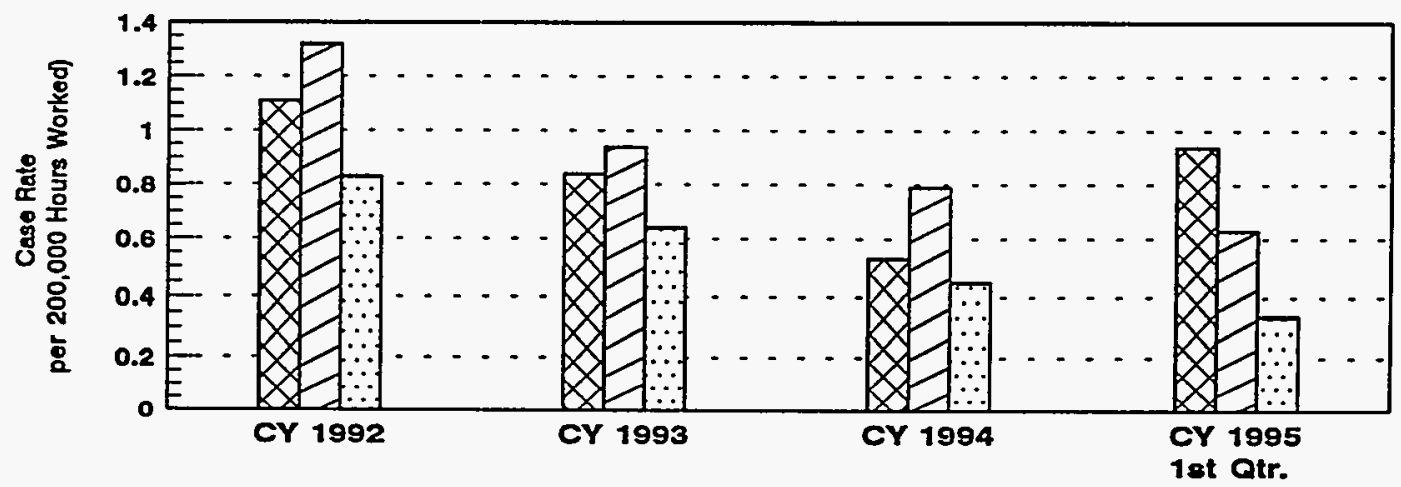

\begin{tabular}{|c|c|c|c|c|}
\hline $\begin{array}{c}\text { First Aid } \\
\text { Case Rate }\end{array}$ & 1.11 & 0.84 & 0.53 & 0.94 \\
\hline $\begin{array}{c}\text { First Aid } \\
\text { Ceses }\end{array}$ & 108 & 88 & 52 & 21 \\
\hline $\begin{array}{c}\text { Total Recordable } \\
\text { Rate }\end{array}$ & 1.32 & 0.84 & 0.78 & 0.83 \\
\hline $\begin{array}{c}\text { Total Recordable } \\
\text { Cases }\end{array}$ & 128 & 100 & 78 & 14 \\
\hline $\begin{array}{c}\text { Lost/Restr. } \\
\text { Case Rate }\end{array}$ & 0.83 & 0.64 & 0.45 & 0.34 \\
\hline $\begin{array}{c}\text { Lost/Restricted } \\
\text { Cases }\end{array}$ & 81 & 68 & 44 & 8 \\
\hline
\end{tabular}

Figure 2-4. Back/Neck Strain Case History Lost/Restricted Workdays

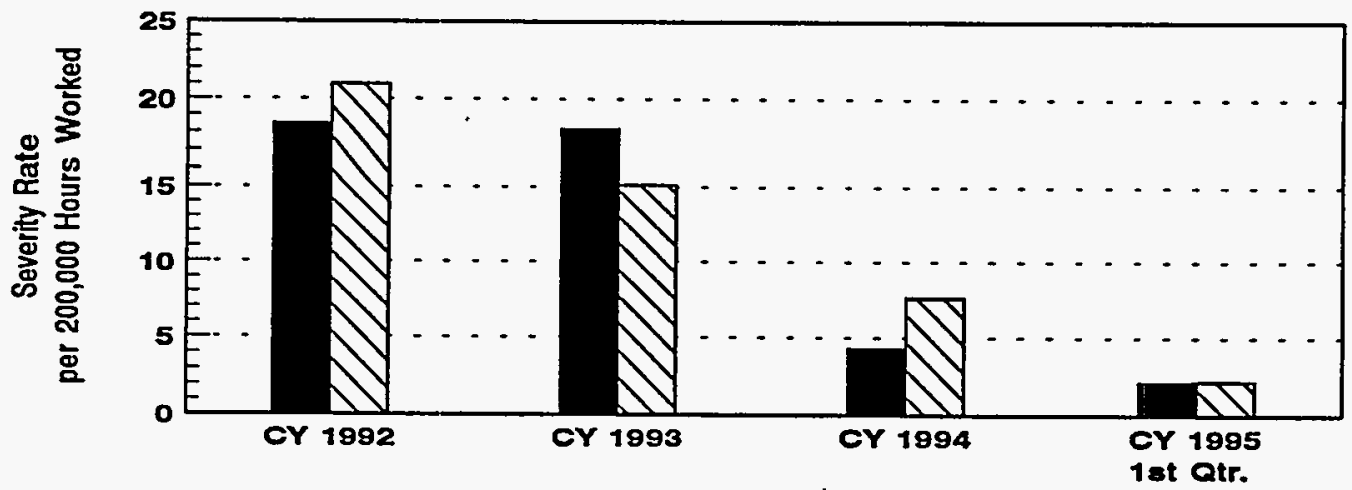

\begin{tabular}{|c|c|c|c|c|}
\hline $\begin{array}{c}\text { Workdays Away } \\
\text { Rate }\end{array}$ & 18.48 & 18.2 & 4.28 & 2.14 \\
\hline $\begin{array}{c}\text { No. of } \\
\text { Workdays Away }\end{array}$ & 1802 & 1934 & 421 & 48 \\
\hline $\begin{array}{c}\text { Restricted Days DV } \\
\text { Rate }\end{array}$ & 20.04 & 15.11 & 7.62 & 2.23 \\
\hline $\begin{array}{c}\text { No. of } \\
\text { Restricted Days }\end{array}$ & 2042 & 1605 & 748 & 50 \\
\hline
\end{tabular}




\subsubsection{All Strain/Sprain Injury Reduction}

Awareness of ergonomic considerations in the workplace, as well as communication regarding the rewards of exercise and fitness, have increased over the past four years. The coinciding improvement in workdays lost are seen as attributable to these efforts (Figure 2-5 and 2-6). Yet, strain/sprain injuries continue to dominate department injury totals. (Refer to Sections 2.5.10 through 2.5.19)

Figure 2-5. All Strain/Sprain Case History Total Recordable Cases/Lost Workday Cases

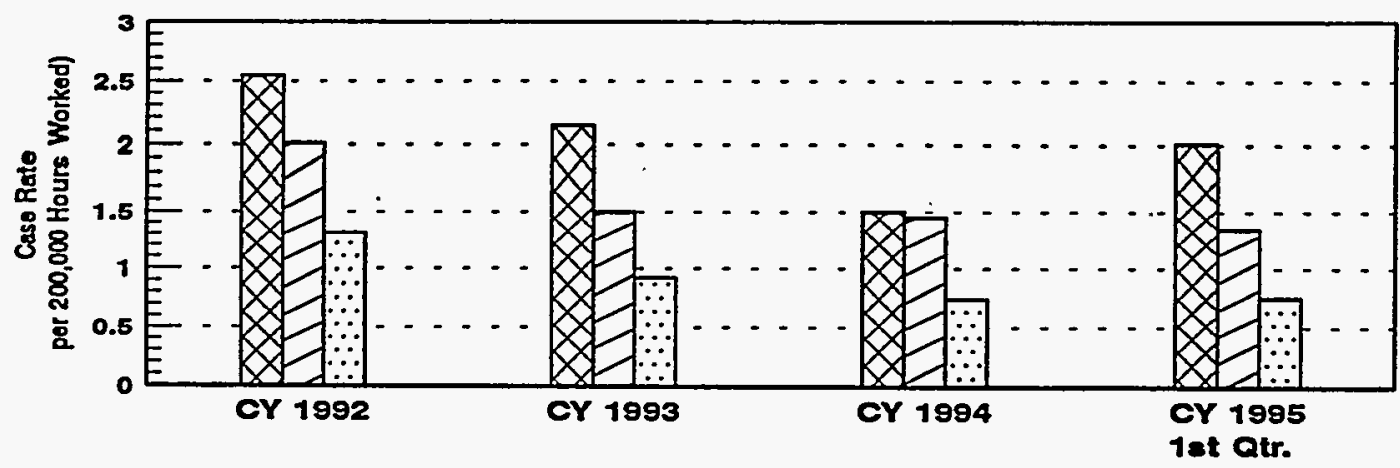

\begin{tabular}{|c|c|c|c|c|}
\hline $\begin{array}{c}\text { Flrst Ald } \\
\text { Caso Rate }\end{array}$ & 2.55 & 2.14 & $\cdot$ & 2.01 \\
\hline $\begin{array}{l}\text { First Ald } \\
\text { Casoe }\end{array}$ & 249 & 227 & 147 & 45 \\
\hline $\begin{array}{l}\text { Total Rocordable } \\
\text { Rate }\end{array}$ & 2.01 & 1.5 & 1.45 & 1.34 \\
\hline $\begin{array}{l}\text { Total Recordable } \\
\text { Casos }\end{array}$ & 180 & 159 & 142 & 30 \\
\hline $\begin{array}{ll}\text { Lost/Rostr. } & \therefore \\
\text { Case Rate } & \therefore\end{array}$ & 1.31 & 0.92 & 0.75 & 0.76 \\
\hline $\begin{array}{l}\text { Lost/fostrioted } \\
\text { Casos }\end{array}$ & 128 & 88 & 74 & 17 \\
\hline
\end{tabular}

Figure 2-6. All Strain/Sprain Caso History Lost/Restricted Workdays

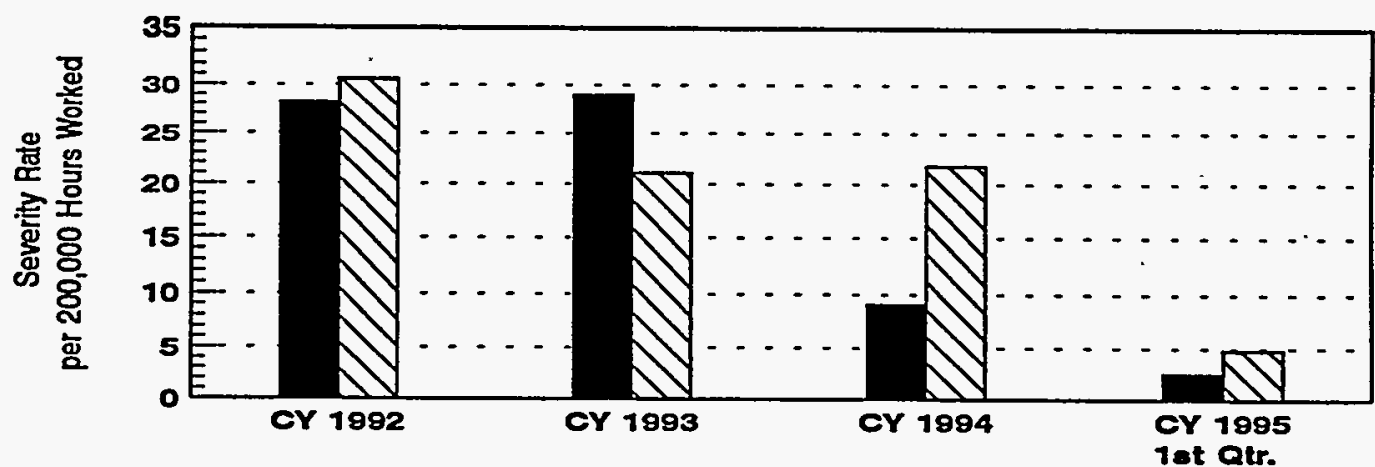

\begin{tabular}{|c|c|c|c|c|}
\hline $\begin{array}{c}\text { Workdays Away } \\
\text { Rate }\end{array}$ & 28.17 & 28.98 & 9.06 & 2.5 \\
\hline $\begin{array}{c}\text { No. of } \\
\text { Workdays Away }\end{array}$ & 2747 & 3079 & 890 & 56 \\
\hline $\begin{array}{c}\text { Restricted Days } \\
\text { Rate }\end{array}$ & 30.53 & 21.03 & 21.74 & 4.82 \\
\hline $\begin{array}{c}\text { No. of } \\
\text { Restricted Days }\end{array}$ & 2978 & 2234 & 2135 & 108 \\
\hline
\end{tabular}




\subsection{CHALLENGES AHEAD/LESSONS IEEARNED}

\subsubsection{Consolidation of Safety Standards}

The effort to create a joint ICF KH / WHC industrial safety manual is progressing at the target pace as four key standards passed internal reviews during the first quarter. We have found additional sources of help through the VPP Outreach Program by utilizing our Dow contact for ideas on producing effective standards.

\subsubsection{Safety Meeting Improvement}

Quality safety meetings are a cornerstone of any successful safety program. Recent audits indicate that not every group is conducting such meetings effectively. WHC is now embarking on an initiative to assure that safety meetings are being used as intended to keep communication lines open and to document the ongoing safety actions of the group.

\subsubsection{Significant Safety/Health Events}

An employee was driving slowly on the right shoulder of the road while looking for the turn to an unfamiliar work location. Upon spotting the turn on the opposite side of the road, the employee pulled the government vehicle back onto the roadway in preparation to turn left. Moments after signaling and beginning the turn, another government vehicle, which was attempting to pass, collided broadside causing extensive damage to both vehicles as well as injury to the two drivers and a passenger of the second car.

This accident fortifies the need to reiterate three main safety 'themes';

- Accident potential is always present. Awareness of what is going on at all times is the first key to accident prevention. If the driver of the first car had noted and gauged all the speeds and distances involved, a better decision would probably have been made.

- Defensive attitudes on the road and on the job can maintain a safe condition. The second car remained in cruise control as the pass was initiated. By not proceeding on the assumption that conditions could suddenly change, the driver gave up a share of control which could have prevented the accident.

- Safety devices make a difference. Because seat belts were worn by all parties involved, the injuries incurred were relatively minor.

\subsection{TOPICS OF INTEREST}

\subsubsection{Safety Resource Center}

Safety Awareness and Performance has safety meeting literature available via Hanford Information, the Safety Meeting Section, on Hanford Local Area Network (HLAN) as a way to 
heighten safety awareness, encourage employee involvement, and make group safety meetings informative. Particular safety topics, with four to five lesson plans, are provided each month. Topics selected for Hanford Information during the first quarter of 1995, were:

\begin{tabular}{lll} 
January 1995 & February 1995 & March 1995 \\
\cline { 2 - 3 } Basic First Aid & Office Safety & Voluntary Protection Program \\
Working in Cold & Safety Attitude & Safety Statistics \\
Conditions & Proper Lifting \& & True to Death Stories \\
Respiratory Protection & Carrying & Hantavirus Infection
\end{tabular}

In addition to the Lesson Plans that are available on Hanford Information, there is also a listing of Safety Meeting Guest Speakers. These are individuals that provide a safety meeting presentation on their area of expertise. The Safety Resource Video Catalog and some Safety Meeting Guidelines and Pointers can also be located in this section of Hanford Information.

Many resources are available through the Safety Resource Center to assist individuals with conducting effective safety meetings, and to provide information on safety and health topics. Employees are encouraged to share these resources with their families and friends. Resources available include videos, literature, awareness items, and support with individual safety programs. For assistance, contact the Safety Resource Center on 376-9059 or visit MO-286, 200 East Area.

\subsection{COMPANY-WIDE AND DEPARTMENT-LEVEL TRENDING AND ANALYSIS}

The following information provides an overview of the incidents being reported on site in the areas of occupational injuries/illnesses, government vehicle accidents, property damage, and fire losses. This is accomplished through the compilation of charts, trending information, and recommendations for improvement. The data has been tabulated and analyzed on both a companywide level and for each department. Management is encouraged to share this information with employees as a way to heighten awareness, realizing that most injuries involve some element of an atrisk behavior. We need to continue to foster a safety culture where all individuals are comfortable looking out for not only their own safety, but the safety of coworkers as well.

All WHC/BCSR occupational injury/illness information is available via Soft Reporting on the HLAN. This report is updated weekly. In addition to providing the number of accidents for each organizational code or facility, the report gives a description of each accident, including location, job-type, and cause of injury. This provides each manager and their employees with a means to focus on what types of accidents are occurring (for trending purposes), and ways to prevent recurrence.

Appendix B-1 provides a list of resources and services available to assist the workforce with injury prevention, accident investigation, and safety awareness efforts.

\subsubsection{Occupational Injury/Illness Incidence Rates}

Overall accident trend indicators were mixed through the first quarter of 1995 . When compared to the same period of a year ago, we find that the rate at which employees reported injuries 
is unchanged. At the same time, however, injuries which caused employees to miss time from work happened only half as frequently. This data reflects a sustained improvement in prioritizing hazard control, as first quarter "lost workday away" severity rates.are 60\% below the 1994 total, and "days lost due to injury" are $80 \%$ lower.

These gains, made in spite of extreme peripheral stressors on the entire Hanford workforce, is an indicator of an improving safety culture. Analysis shows that awareness of potential hazards remained high during the months of January and February, even as impending workforce reductions were being announced.

Table 2-2. WHC Occupational Injury/lllness CY 1994 - CY 1995 Statistics Comparison

\begin{tabular}{|c|c|c|c|c|}
\hline Time Period & $\begin{array}{c}\text { First Aid } \\
\text { Cases }\end{array}$ & $\begin{array}{c}\text { First Aid } \\
\text { Case Rate }\end{array}$ & $\begin{array}{c}\text { Total } \\
\text { Recordable Cases }\end{array}$ & $\begin{array}{c}\text { Total Recordable } \\
\text { Case Incidence Rate }\end{array}$ \\
\hline \hline CY 1994 & 760 & 7.74 & 397 & 4.04 \\
\hline 1st Qtr 1994 & 187 & 7.24 & 93 & 3.60 \\
\hline 1st Qtr 1995 & 162 & 7.23 & 68 & 3.04 \\
\hline
\end{tabular}

\begin{tabular}{|c|c|c|c|c|c|c|}
\hline Time Period & $\begin{array}{c}\text { Recordable } \\
\text { Cases } \\
\text { Resulting in } \\
\text { Lost/Restricted } \\
\text { Workdays }\end{array}$ & $\begin{array}{c}\text { Lost/ } \\
\text { Restricted } \\
\text { Workday } \\
\text { Case } \\
\text { Incidence } \\
\text { Rate }\end{array}$ & $\begin{array}{c}\text { Cases } \\
\text { Involving } \\
\text { Days Away } \\
\text { from Work }\end{array}$ & $\begin{array}{c}\text { Lost } \\
\text { Workday } \\
\text { Away Only } \\
\text { Case } \\
\text { Incidence } \\
\text { Rate }\end{array}$ & $\begin{array}{c}\text { Cases } \\
\text { Involving } \\
\text { Days of } \\
\text { Restricted } \\
\text { Work } \\
\text { Activity Only }\end{array}$ & $\begin{array}{c}\text { Restricted } \\
\text { Work } \\
\text { Activity } \\
\text { Only Case } \\
\text { Incidence } \\
\text { Rate }\end{array}$ \\
\hline \hline CY. 1994 & 114 & 1.16 & 67 & 0.68 & 47 & 0.48 \\
\hline 1st Qtr 1994 & 23 & 0.89 & 15 & 0.58 & 8 & 0.31 \\
\hline 1st Qtr 1995 & 25 & 1.12 & 6 & 0.27 & 19 & 0.85 \\
\hline
\end{tabular}

\begin{tabular}{|c|c|c|c|c|c|c|}
\hline Time Period & $\begin{array}{c}\text { No. of } \\
\text { Lost/ } \\
\text { Restricted } \\
\text { Workdays }\end{array}$ & $\begin{array}{c}\text { Lostl } \\
\text { Restricted } \\
\text { Workday } \\
\text { Severity Rate }\end{array}$ & $\begin{array}{c}\text { No. of } \\
\text { Workdays } \\
\text { Away Only }\end{array}$ & $\begin{array}{c}\text { Workdays } \\
\text { Away Only } \\
\text { Severity } \\
\text { Rate. }\end{array}$ & $\begin{array}{c}\text { No. of Days } \\
\text { Restricted } \\
\text { Work Activity }\end{array}$ & $\begin{array}{c}\text { Restricted } \\
\text { Work Activity } \\
\text { Severity } \\
\text { Rate }\end{array}$ \\
\hline \hline CY 1994 & 3,997 & 40.70 & 1,374 & 13.99 & 2,623 & 26.71 \\
\hline 1st Qtr 1994 & 1,126 & 43.60 & 320 & 12.39 & 806 & 31.21 \\
\hline 1st Qtr 1995 & 300 & 13.40 & 56 & 2.50 & 244 & 10.90 \\
\hline
\end{tabular}




\subsubsection{Lost/Restricted Workday Case Incidence Rates}

The cumulative CY 1995 first quarter lost/restricted workday case incidence rate (1.12) is 3 percent below the company's CY 1994 rate (1.16), and also 34 percent below the DOE 1991-93 Average (1.70). (Figure 2-7).

The 1995 first quarter rate (1.12) is higher than the 1994 first quarter rate (0.89). This increase is concentrated in those cases which result in restricted work activities, where the rate nearly triples $(0.31$ to 0.85$)$. Cases resulting in days away from the job actually fell be 60 percent from CY 1994. It is noteworthy that restricted workday rates, that is the number of days restricted for each injury, fell just as sharply (from a CY 1994 first quarter rate of 31.21 to a CY 1995 first quarter rate of 10.90), as the restricted case rate rose. This is yet another indication that injuries-are being managed competently, to allow employees to remain proactive at the same time injuries are allowed to repair.

The control chart (Figure 2-8) plots the CY 1990 through CY 1995 first quarter monthly lost/restricted workday case incidence rates. A control line shift took place in May 1993 when WHC initiated its "Making Safety First: Campaign '93."

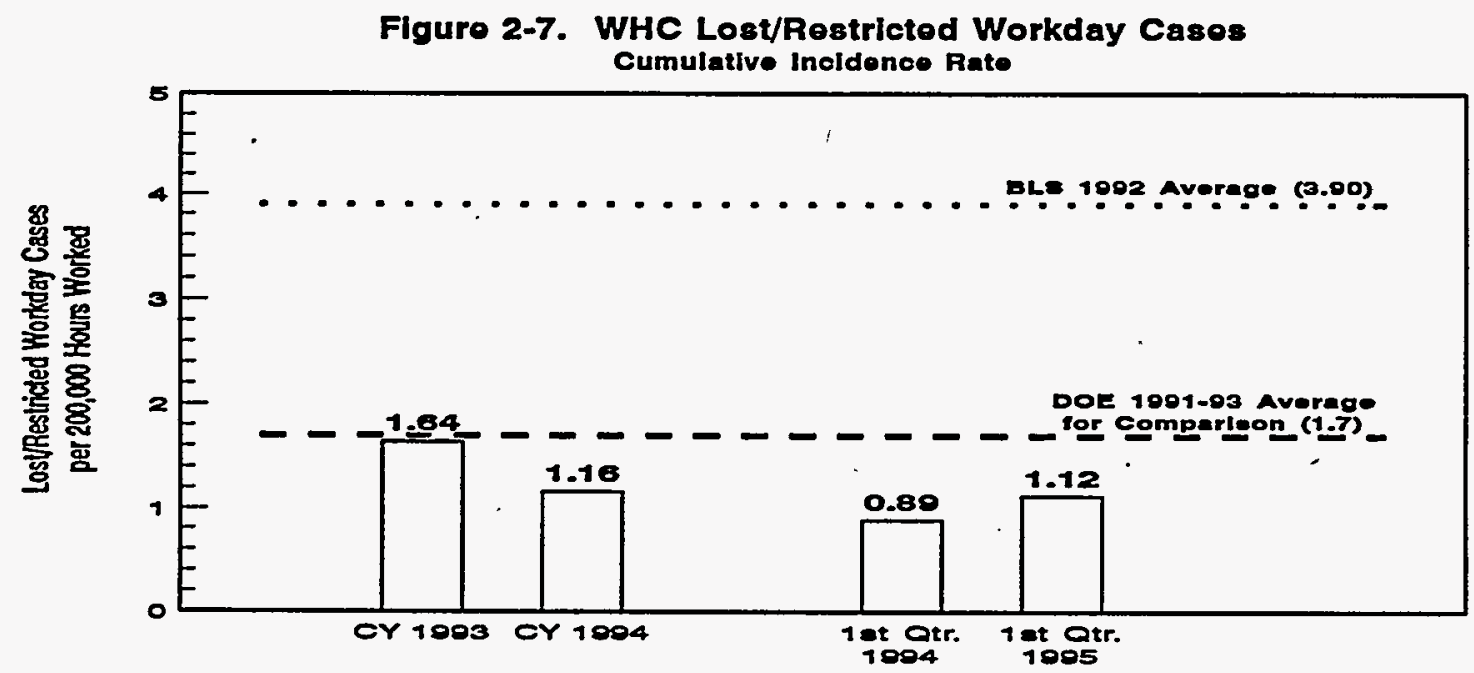

FIgure 2-8. WHC Lost/Restricted Workday Case Monthly Incldonce Rates CY 1890 - CYTD 1995 - 3 Standard Dovlations

or 1000 - OY 1003 Monthly Rates Include groipe thax zransforred to ICF KH Operatlons on 01/01/04

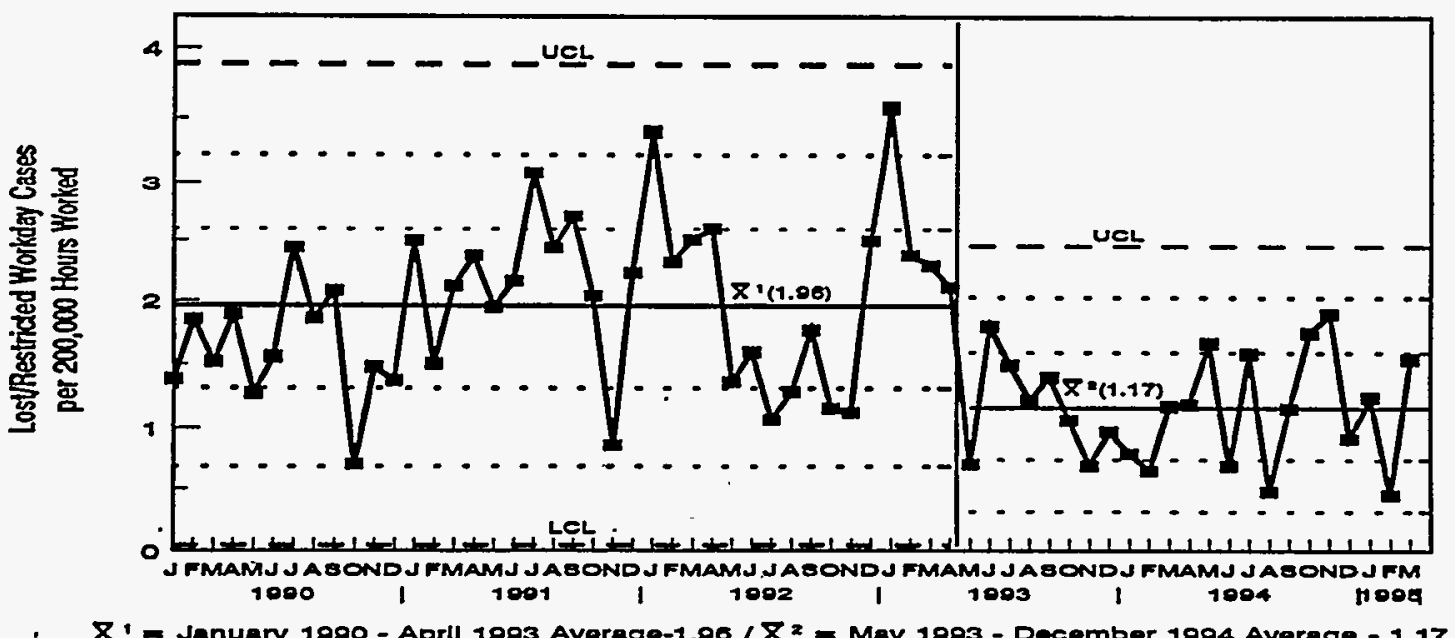




\subsubsection{Lost/Restricted Workday Incidence Rates}

Figure 2-9 provides the CY 1995 first quarter breakdown by departments of the lost workday away and restricted workday incidence rates. The combined cumulative CY 1995 first quarter lost workday away (2.50) and restricted workday (10.90) incidence rates of 13.40 are 71 percent below the DOE 1991-93 Average (45.90). Some of the injuries that occurred during the first quarter are continuing to accumulate days, which will affect the incidence rates.

The control chart (Figure 2-10) plots the CY 1990 through CY 1995 first quarter monthly lost/restricted workday incidence rates. A control line shift took place in May 1993 when WHC initiated its "Making Safety First: Campaign '93."

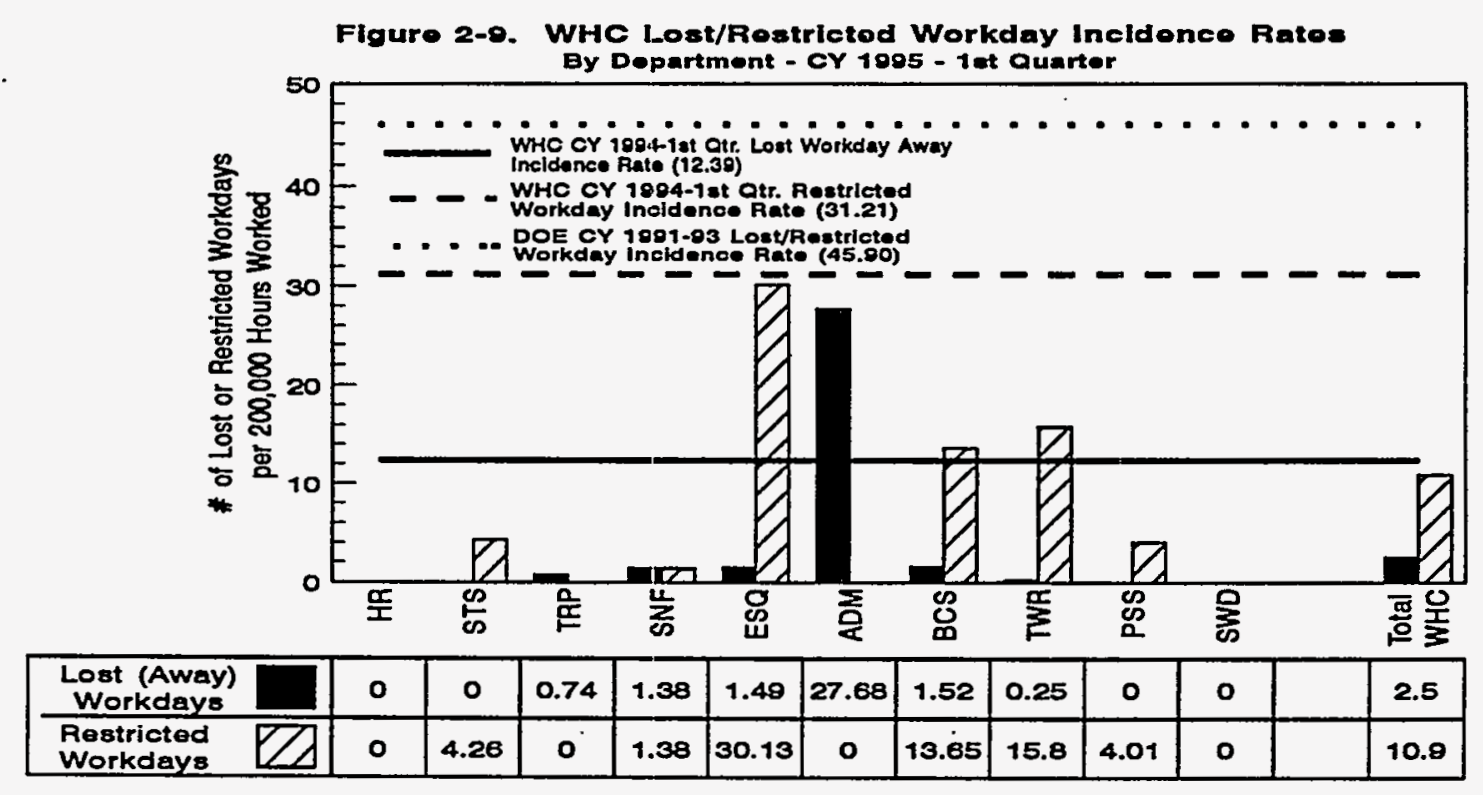

Figure 2-10. WHC LOs(URostrictod WORKDAY Monthly Incidonce Rates CY 1980 - CYTD 1985 - 3 Standard Dovlations

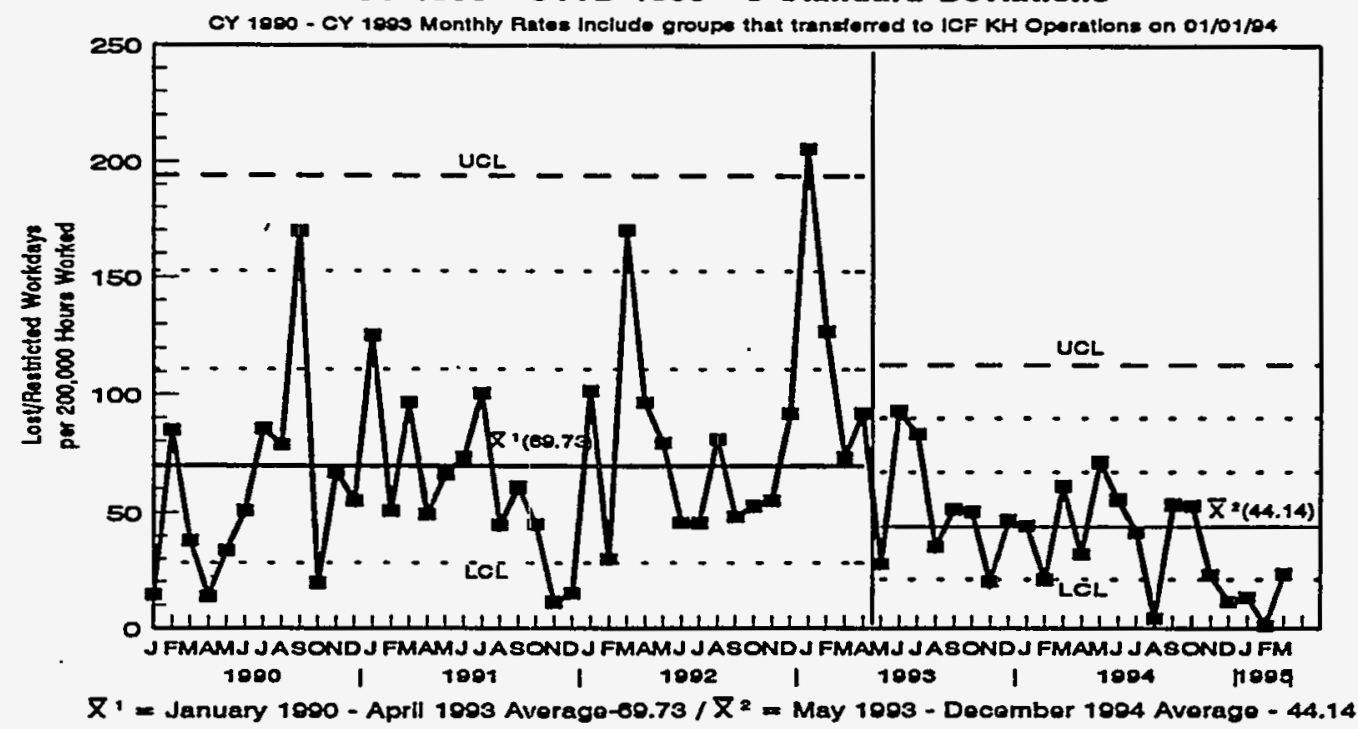




\subsubsection{Total Recordable Case Incidence Rates}

The cumulative CY 1995 first quarter total recordable case incidence rate (3.04) is 16 percent below the company's CY 1994 first quarter rate (3.60), 25 percent below the company's CY 1994 rate (4.04), and 18 percent below the DOE CY 1991-93 Average (3.73). (Figure 2-11).

The control chart (Figure 2-12) plots the CY 1990 through CY 1995 first quarter monthly total recordable case incidence rates. A control line shift took place in May 1993 when WHC initiated its "Making Safety First: Campaign '93."

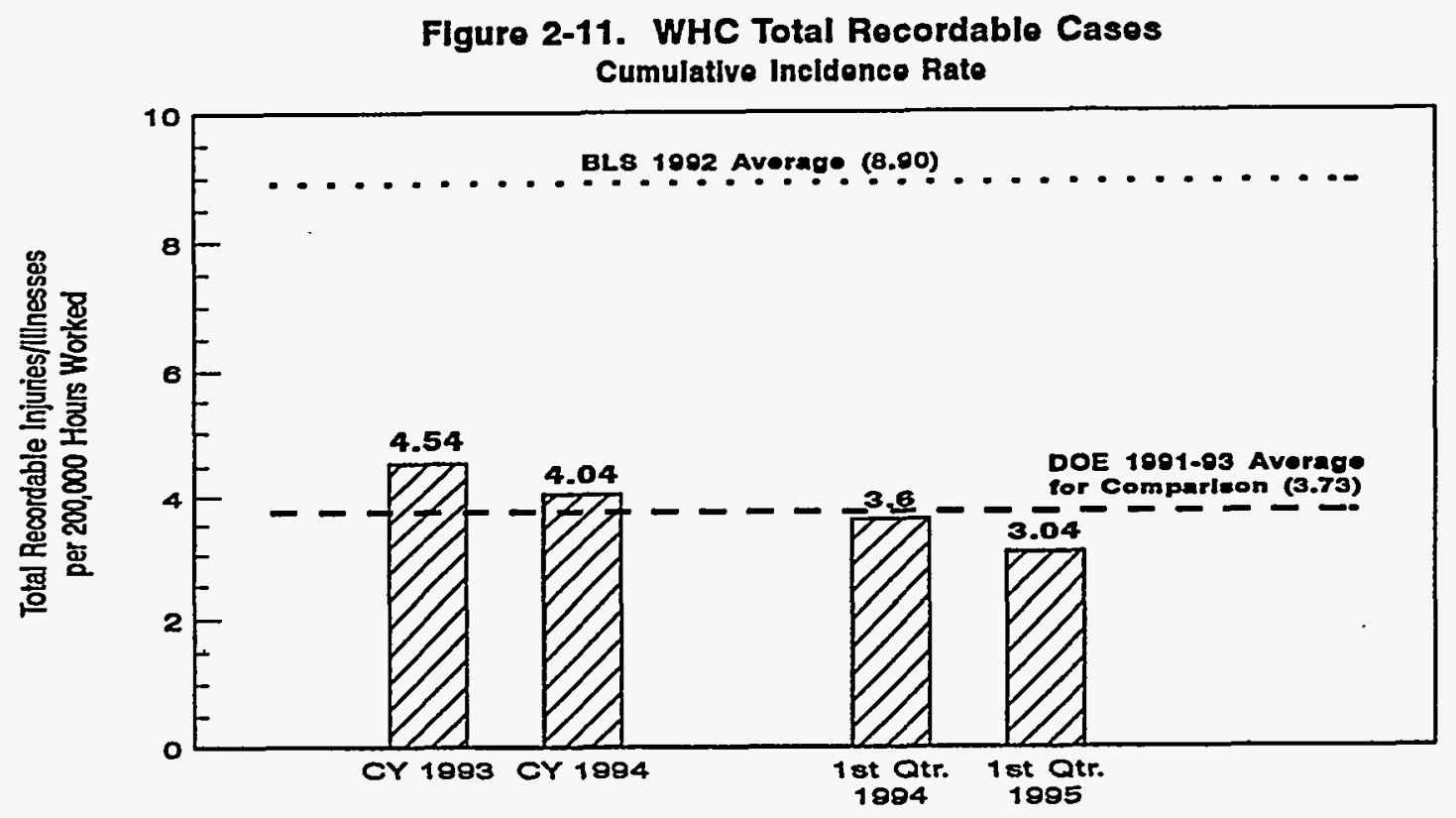

Figure 2-12. WHC Total Recordable Case Monthly Incidence Rates CY 1990 - CYTD 1995 - 3 Standard Doviatlons

CY 1990 - CY 1993. Monthly Rates include groups that transferred to ICF KH Operations on 01/01/94

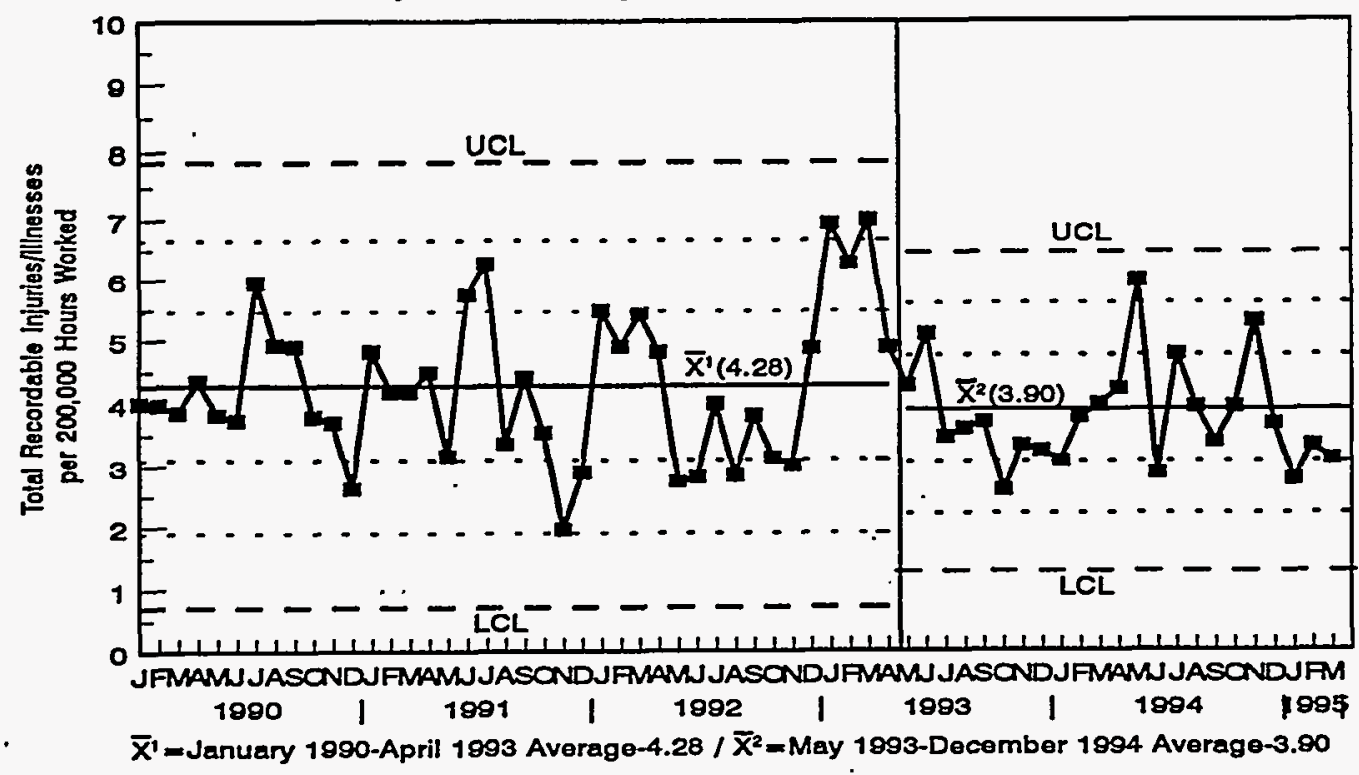


WHC-SP-0564-37

2.5.5 Occupational Injuries/Illnesses By Type

Figure 2-13. First Ald Only by Type (162 Cases)

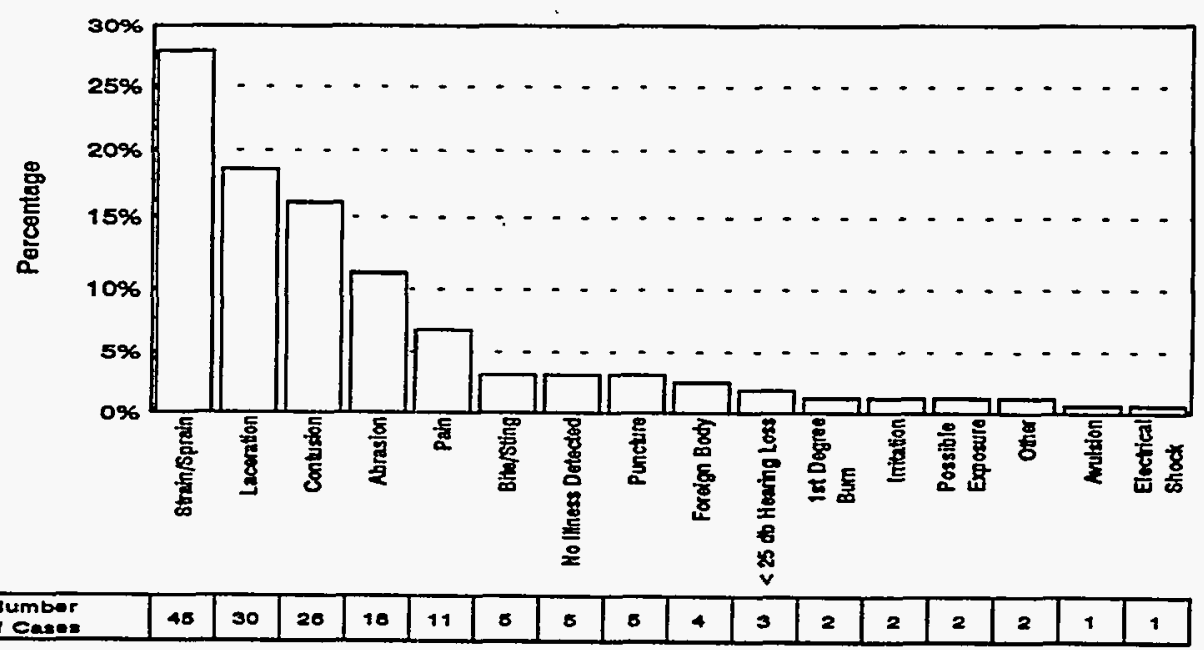

Flgure 2-14. Total Reoordable Injuries/lilnesses by Type (68 Cases)

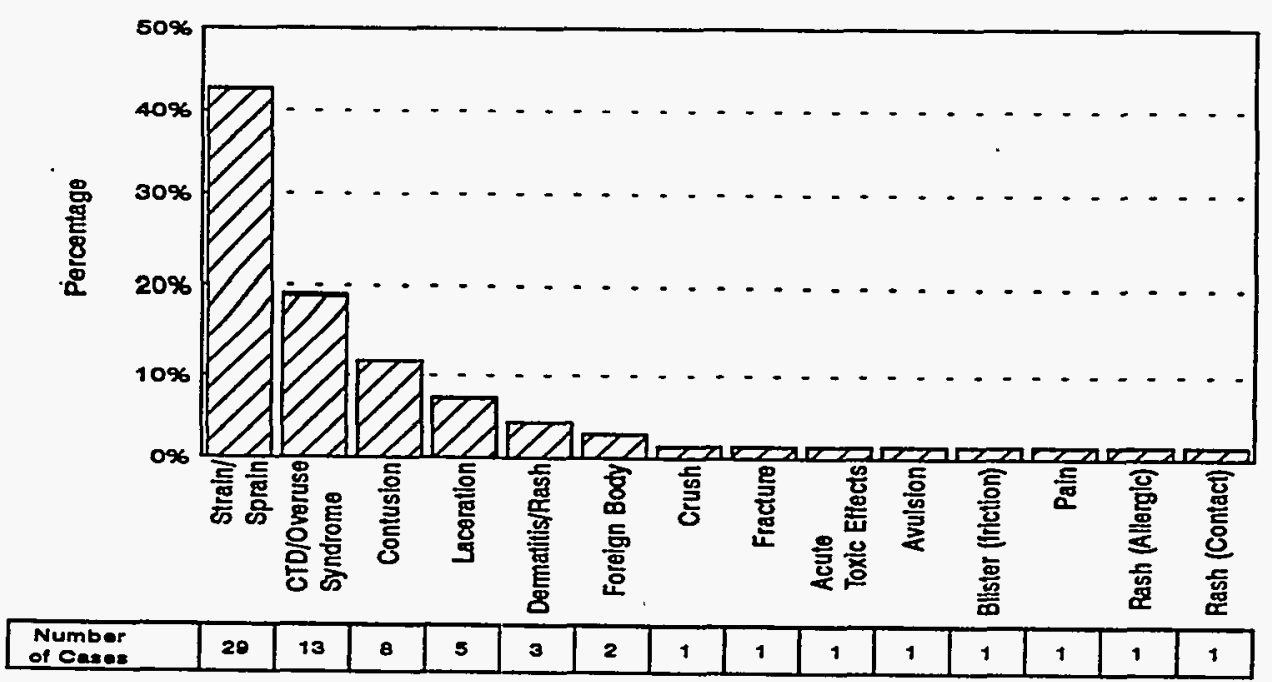

Figure 2-15. Lost/Restricted Workday Cases by Type (25 Cases)

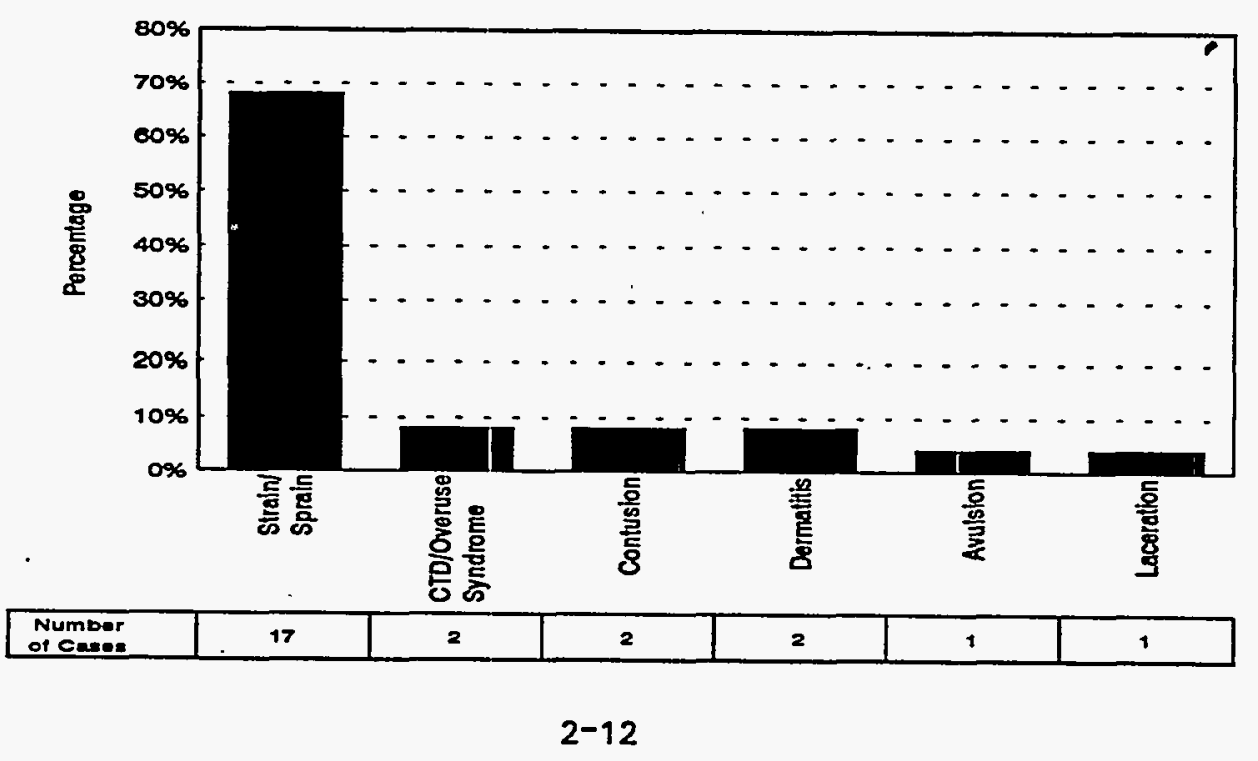


2.5.6 Occupational Injuries/Illnesses By Body Group Injured

Figure 2-16. First Ald Only by Body Group Injured (162 Cases)

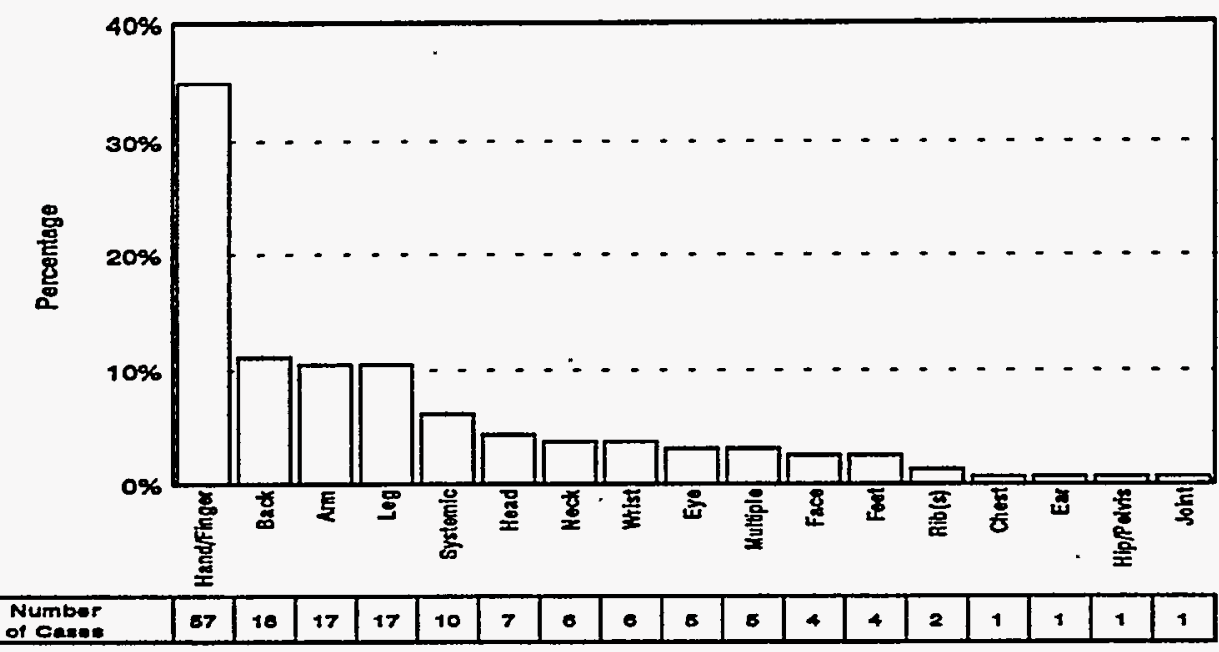

Flgure 2-17. Total Recordabie Injuries/llinesses by Body Group Injured (68 Cases)

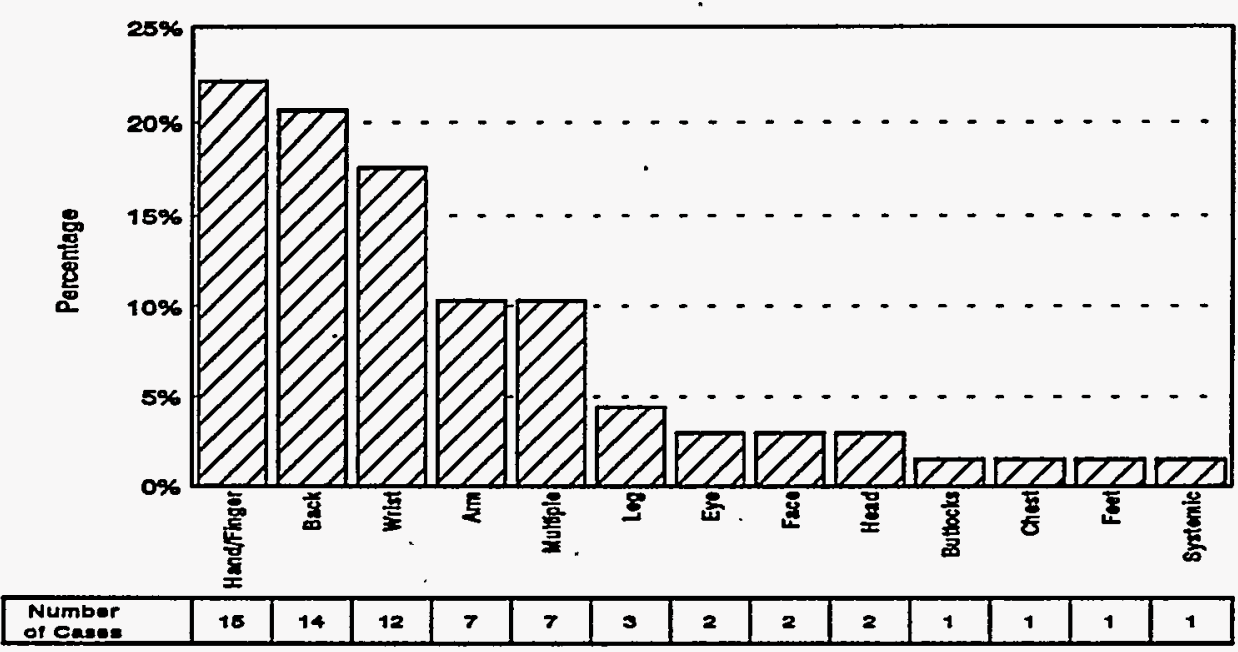

Figure 2-18. Lost/Restricted Workday Cases by Body Group Injured (25 Cases)

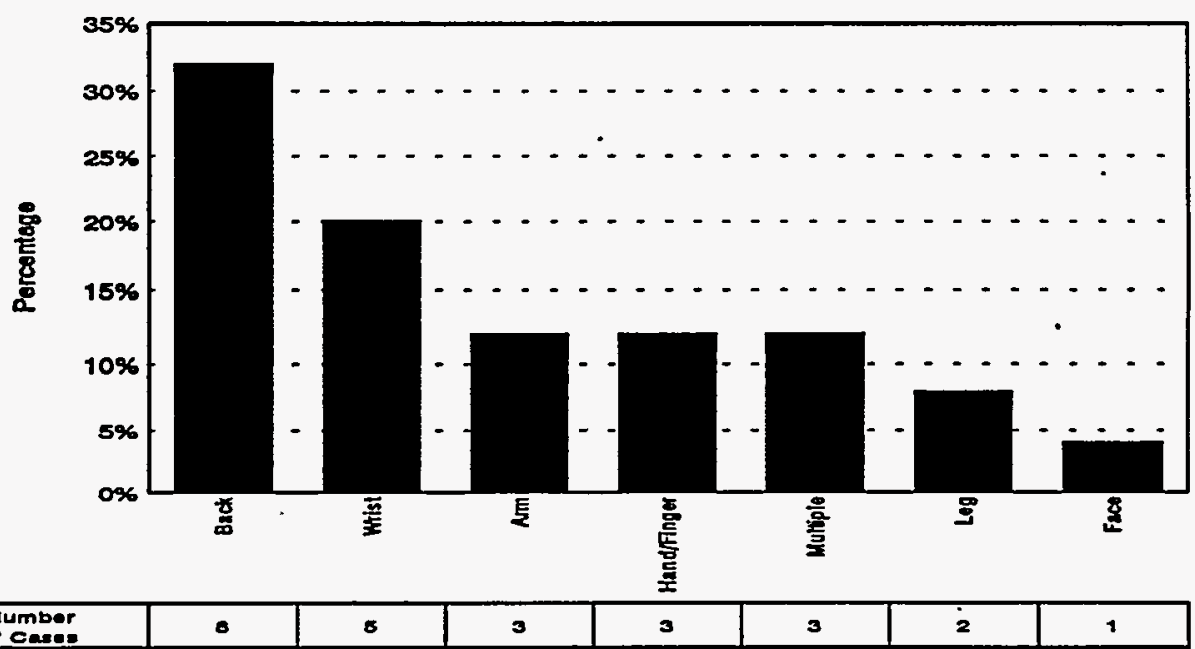




\subsubsection{Occupational Injuries/Illnesses By Cause}

Figure 2-19. First Ald Only by Cause (162 Caees)

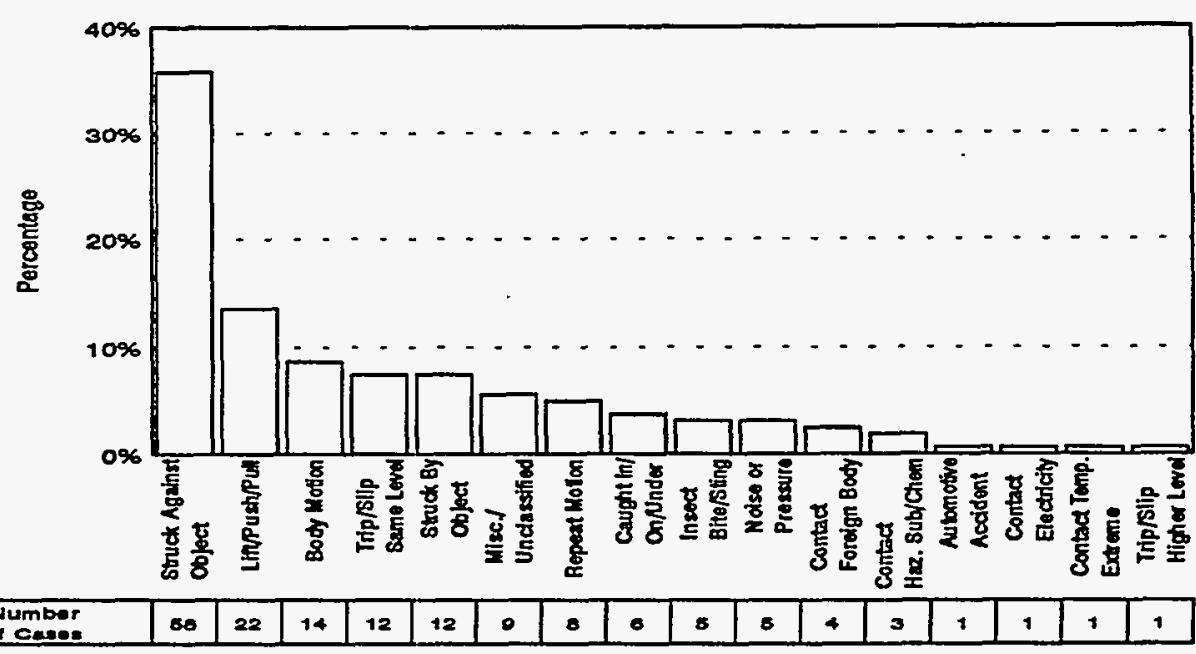

Figure 2-20. Total Rocordable Injurles/linesses by Cause (68 Cases)

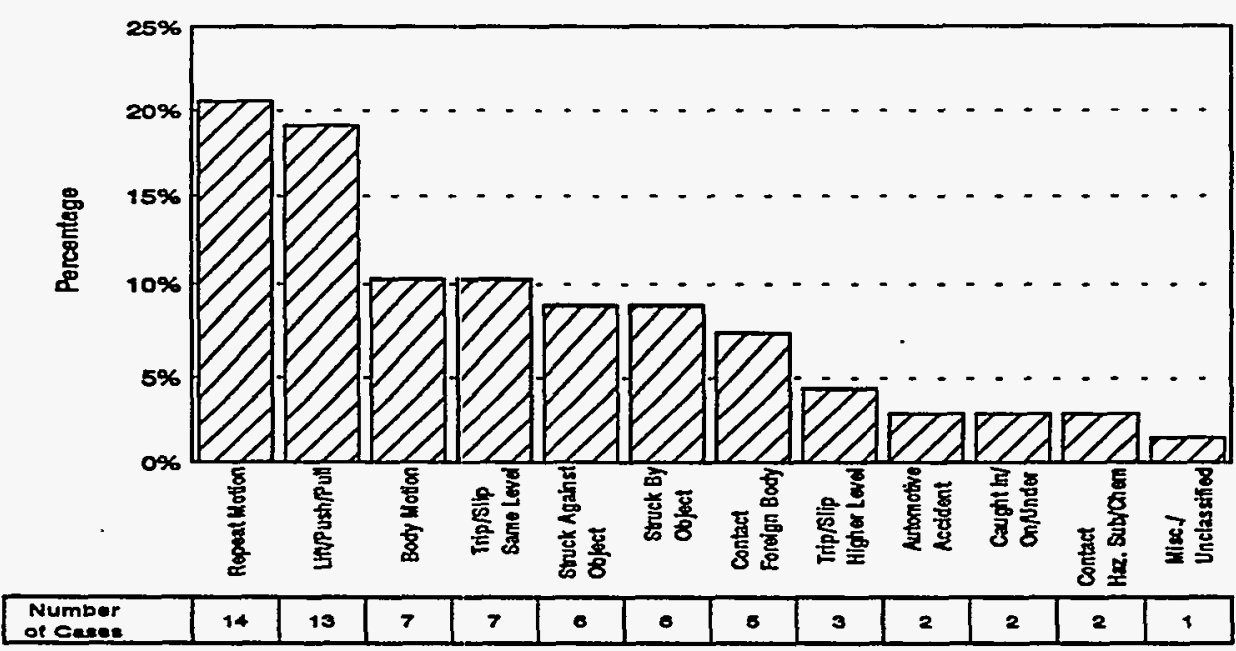

Figure 2-21. Lost/Restricted Workday Cases by Cause (25 Cases)

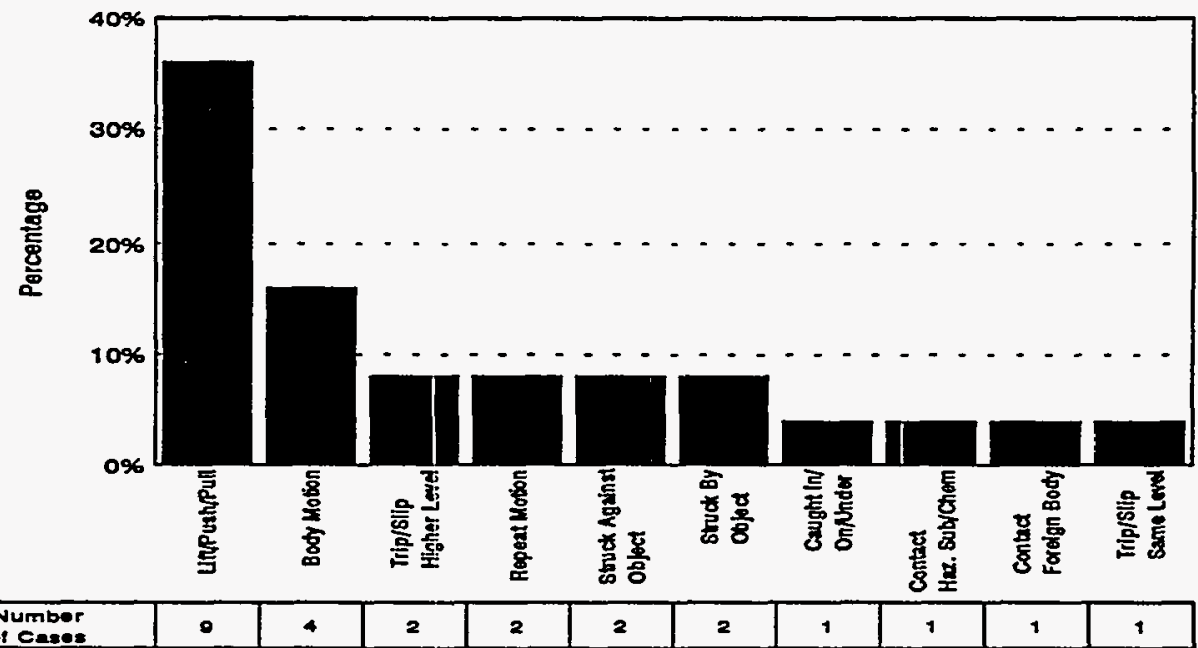


2.5.8 Occupational Injuries/Illnesses By Job Type

Figure 2-22. First Ald Only by Job Typo (162 Cases)

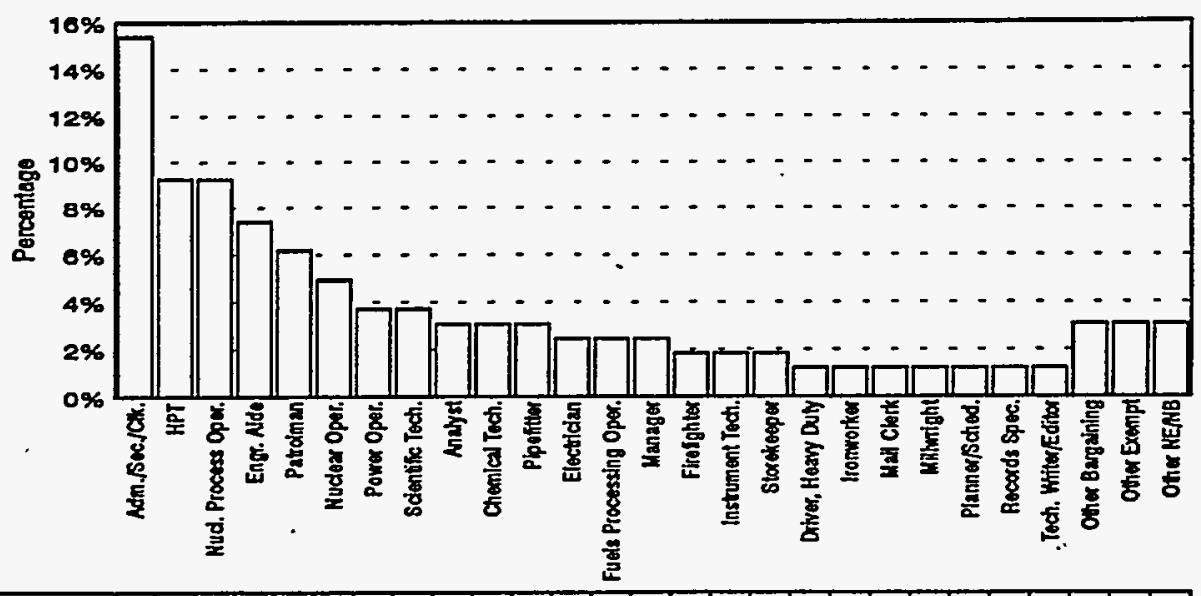

\begin{tabular}{|l|l|l|l|l|l|l|l|l|l|l|l|l|l|l|l|l|l|l|l|l|l|l|l|l|l|l|l|}
\hline $\begin{array}{l}\text { Number } \\
\text { of Cale: }\end{array}$ & 25 & 18 & 18 & 12 & 10 & 0 & 0 & 0 & 5 & 5 & 5 & 4 & 4 & 4 & 3 & 3 & 5 & 2 & 2 & 2 & 2 & 2 & 2 & 2 & 5 & 6 & 5 \\
\hline
\end{tabular}

Figure 2-23. Total Reoordable Injuries/IIInesses by Job Type (68 Cases)

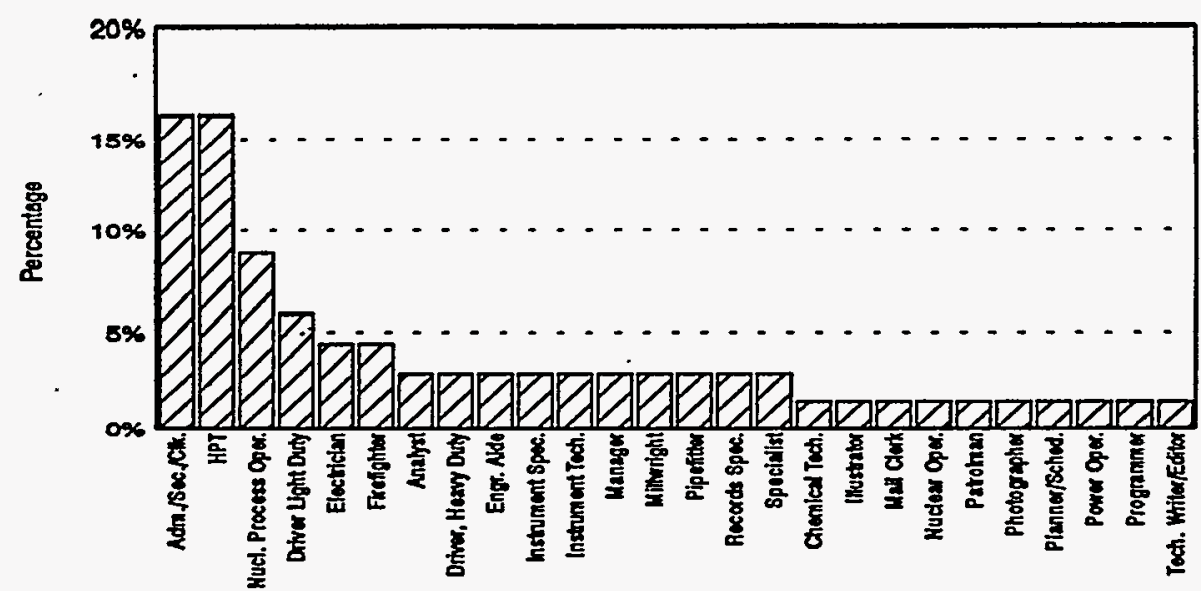

\begin{tabular}{|l|l|l|l|l|l|l|l|l|l|l|l|l|l|l|l|l|l|l|l|l|l|l|l|l|l|l|}
\hline $\begin{array}{l}\text { Numbor } \\
\text { Of Canes }\end{array}$ & 11 & 11 & 6 & 4 & 3 & 3 & 2 & 2 & 2 & 2 & 2 & 2 & 2 & 2 & 2 & 2 & 1 & 1 & 1 & 1 & 1 & 1 & 1 & 1 & 1 & 1 \\
\hline
\end{tabular}

Figure 2-24. Lost/Restricted Workday Cases by Job Type (25 Cases)

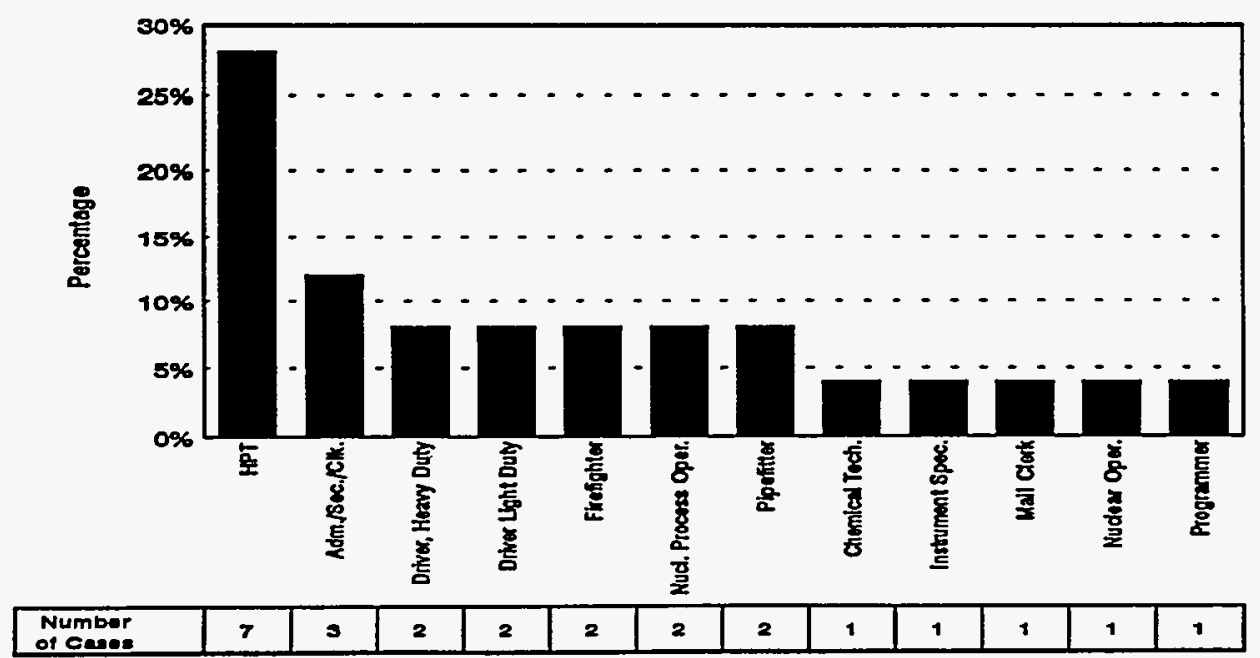


WHC-SP-0564-37

2.5.9 Occupational Injuries/lllnesses By Facility
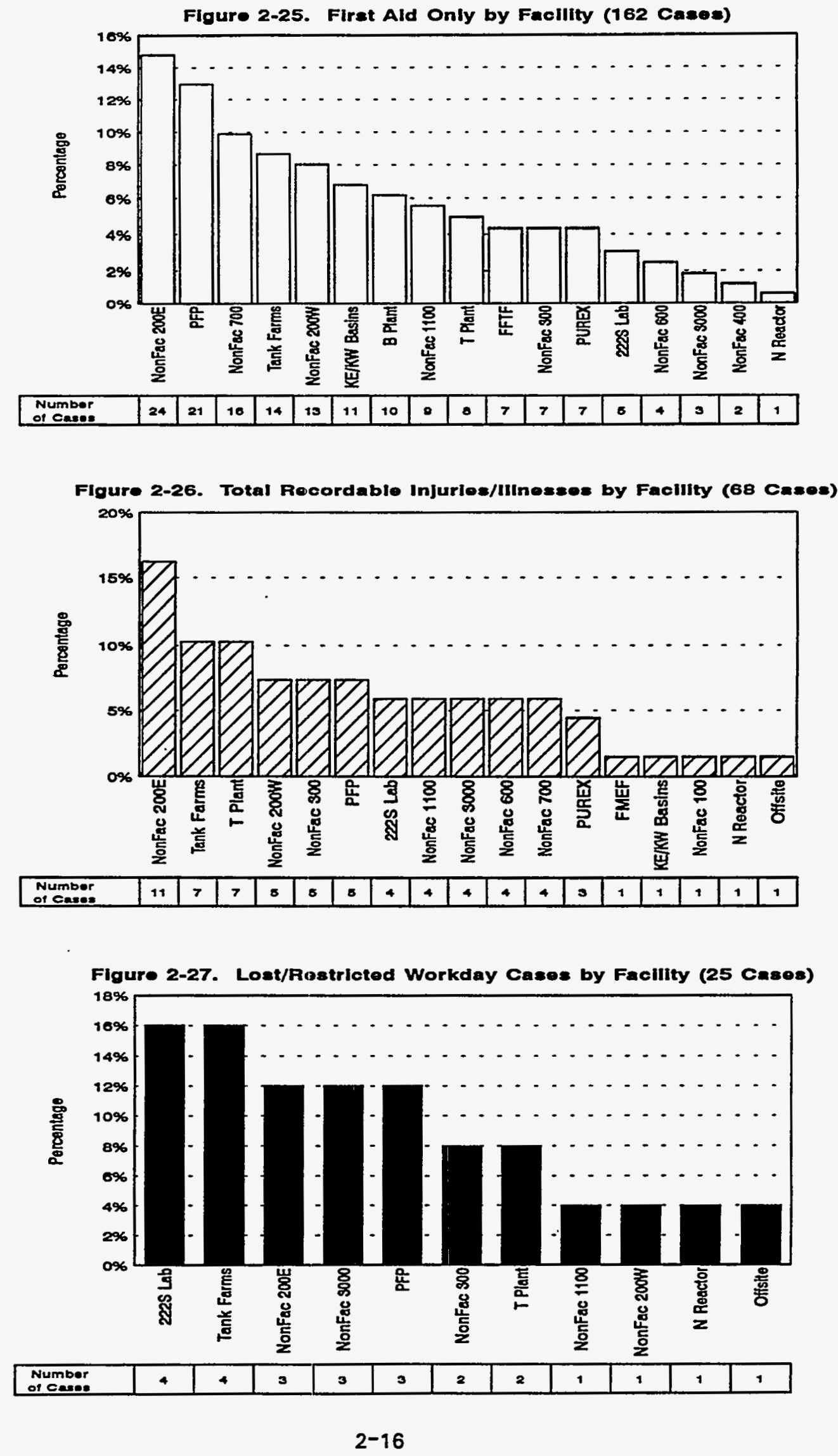


\subsubsection{Human Resources (HR)}

The numbers in Tables 2-3 and 2-4 reflect the job-related injuries/illnesses reported by HR personnel during CY 1995 through the first quarter.

Table 2-3. HR Occupational Injury/Illness

CY 1994 - CY 1995 Statistics Comparison

\begin{tabular}{|c|c|c|c|c|}
\hline Time Period & $\begin{array}{c}\text { First Aid } \\
\text { Cases }\end{array}$ & $\begin{array}{c}\text { First Aid } \\
\text { Case Rate }\end{array}$ & $\begin{array}{c}\text { Total } \\
\text { Recordable Cases }\end{array}$ & $\begin{array}{c}\text { Total Recordable } \\
\text { Case Incidence Rate }\end{array}$ \\
\hline \hline CY 1994 & 9 & 3.09 & 1 & 0.34 \\
\hline 1st Qtr 1994 & 2 & 2.66 & 0 & 0 \\
\hline 1st Qtr 1995 & 2 & 3.11 & 0 & 0 \\
\hline
\end{tabular}

\begin{tabular}{|c|c|c|c|c|c|c|}
\hline Time Period & $\begin{array}{c}\text { Recordable } \\
\text { Cases } \\
\text { Resulting in } \\
\text { Lost/Restricted } \\
\text { Workdays }\end{array}$ & $\begin{array}{c}\text { Lost/ } \\
\text { Restricted } \\
\text { Workday } \\
\text { Case } \\
\text { Incidence } \\
\text { Rate }\end{array}$ & $\begin{array}{c}\text { Cases } \\
\text { Involving } \\
\text { Days Away } \\
\text { from Work }\end{array}$ & $\begin{array}{c}\text { Lost Workday } \\
\text { Away Only } \\
\text { Case Incidence } \\
\text { Rate }\end{array}$ & $\begin{array}{c}\text { Cases } \\
\text { Involving Days } \\
\text { of Restricted } \\
\text { Work Activity } \\
\text { Only }\end{array}$ & $\begin{array}{c}\text { Restricted } \\
\text { Work } \\
\text { Activity } \\
\text { Only Case } \\
\text { Incidence } \\
\text { Rate }\end{array}$ \\
\hline CY 1994 & 0 & 0 & 0 & 0 & 0 & 0 \\
\hline 1st Qtr 1994 & 0 & 0 & 0 & 0 & 0 & 0 \\
\hline 1st Qtr 1995 & 0 & 0 & 0 & 0 & 0 & 0 \\
\hline
\end{tabular}

\begin{tabular}{|c|c|c|c|c|c|c|}
\hline Time Period & $\begin{array}{c}\text { No. of } \\
\text { Lost/ } \\
\text { Restricted } \\
\text { Workdays }\end{array}$ & $\begin{array}{c}\text { Lost/ } \\
\text { Restricted } \\
\text { Workday } \\
\text { Severity Rate }\end{array}$ & $\begin{array}{c}\text { No. of } \\
\text { Workdays } \\
\text { Away Only }\end{array}$ & $\begin{array}{c}\text { Workdays } \\
\text { Away Only } \\
\text { Severity } \\
\text { Rate }\end{array}$ & $\begin{array}{c}\text { No. of Days } \\
\text { Restricted } \\
\text { Work Activity }\end{array}$ & $\begin{array}{c}\text { Restricted } \\
\text { Work Activity } \\
\text { Severity } \\
\text { Rate }\end{array}$ \\
\hline \hline CY 1994 & 0 & 0 & 0 & 0 & 0 & 0 \\
\hline 1st Qtr 1994 & 0 & 0 & 0 & 0 & 0 & 0 \\
\hline 1st Qtr 1995 & 0 & 0 & 0 & 0 & 0 & 0 \\
\hline
\end{tabular}

Table 2-4. HR Occupational Injuries/lllnesses By Type - 1st Qtr. 1995

\begin{tabular}{|c|c|c|c|c|}
\hline Type & $\begin{array}{c}\text { All Cases } \\
\text { (First Aid/ } \\
\text { Recordable/ } \\
\text { Lost/Restricted }\end{array}$ & All Case Rate & $\begin{array}{c}\text { Cases Resulting } \\
\text { in Lost or } \\
\text { Restricted Workdays }\end{array}$ & $\begin{array}{c}\text { Lost or Restricted } \\
\text { Workday Case } \\
\text { Incidence Rate }\end{array}$ \\
\hline \hline All Strain/Sprain & 0 & 0 & 0 & 0 \\
\hline $\begin{array}{c}\text { Cumulative Trauma } \\
\text { Disorder }\end{array}$ & 0 & 0 & 0 & 0 \\
\hline All Other & 2 & 3.11 & 0 & 0 \\
\hline
\end{tabular}




\subsubsection{Strategic Affairs/Technical Support (STS)}

The numbers in Tables 2-5 and 2-6 reflect the job-related injuries/illnesses reported by STS personnel during CY 1995 through the first quarter.

Table 2-5. STS Occupational Injury/lllness

CY 1994 - CY 1995 Statistics Comparison

\begin{tabular}{|c|c|c|c|c|}
\hline Time Period & $\begin{array}{c}\text { First Aid } \\
\text { Cases }\end{array}$ & $\begin{array}{c}\text { First Aid } \\
\text { Case Rate }\end{array}$ & $\begin{array}{c}\text { Total } \\
\text { Recordable Cases }\end{array}$ & $\begin{array}{c}\text { Total Recordable } \\
\text { Case Incidence Rate }\end{array}$ \\
\hline \hline CY 1994 & 14 & 5.31 & 16 & 6.07 \\
\hline 1st Qtr 1994 & 0 & 0 & 0 & 0 \\
\hline 1st Qtr 1995 & 3 & 3.19 & 2 & 2.13 \\
\hline
\end{tabular}

\begin{tabular}{|c|c|c|c|c|c|c|}
\hline Time Period & $\begin{array}{c}\text { Recordable } \\
\text { Cases } \\
\text { Resulting in } \\
\text { Lost/Restricted } \\
\text { Workdays }\end{array}$ & $\begin{array}{c}\text { Lost/ } \\
\text { Restricted } \\
\text { Workday } \\
\text { Case } \\
\text { Incidence } \\
\text { Rate }\end{array}$ & $\begin{array}{c}\text { Cases } \\
\text { Involving } \\
\text { Days Away } \\
\text { from Work }\end{array}$ & $\begin{array}{c}\text { Lost Workday } \\
\text { Away Only } \\
\text { Case Incidence } \\
\text { Rate }\end{array}$ & $\begin{array}{c}\text { Cases } \\
\text { Involving Days } \\
\text { of Restricted } \\
\text { Work Activity } \\
\text { Only }\end{array}$ & $\begin{array}{c}\text { Restricted } \\
\text { Work } \\
\text { Activity } \\
\text { Only Case } \\
\text { Incidence } \\
\text { Rate }\end{array}$ \\
\hline \hline CY 1994 & 5 & 1.90 & 3 & 1.14 & 2 & 0.76 \\
\hline 1st Qtr 1994 & 0 & 0 & 0 & 0 & 0 & 0 \\
\hline 1st Qtr 1995 & 1 & 1.06 & 0 & 0 & 1 & 1.06 \\
\hline
\end{tabular}

\begin{tabular}{|c|c|c|c|c|c|c|}
\hline Time Period & $\begin{array}{c}\text { No. of } \\
\text { Lost/ } \\
\text { Restricted } \\
\text { Workdays }\end{array}$ & $\begin{array}{c}\text { Lost/ } \\
\text { Restricted } \\
\text { Workday } \\
\text { Severity Rate }\end{array}$ & $\begin{array}{c}\text { No. of } \\
\text { Workdays } \\
\text { Away Only }\end{array}$ & $\begin{array}{c}\text { Workdays } \\
\text { Away Only } \\
\text { Severity } \\
\text { Rate }\end{array}$ & $\begin{array}{c}\text { No. of Days } \\
\text { Restricted } \\
\text { Work Activity }\end{array}$ & $\begin{array}{c}\text { Restricted } \\
\text { Work Activity } \\
\text { Severity } \\
\text { Rate }\end{array}$ \\
\hline \hline CY 1994 & 49 & 18.59 & 43 & 16.32 & 6 & 2.28 \\
\hline 1st Qtr 1994 & 0 & 0 & 0 & 0 & 0 & 0 \\
\hline 1st Qtr 1995 & 4 & 4.26 & 0 & 0 & 4 & 4.26 \\
\hline
\end{tabular}

Table 2-6. STS Occupational Injuries/Illnesses By Type - 1st Qtr. 1995

\begin{tabular}{|c|c|c|c|c|}
\hline Type & $\begin{array}{c}\text { All Cases } \\
\text { (First Aid } \\
\text { Recordable/ } \\
\text { Lost/Restricted) }\end{array}$ & All Case Rate & $\begin{array}{c}\text { Cases Resulting } \\
\text { in Iost or } \\
\text { Restricted Workdays } \\
\text { Incidence Rate }\end{array}$ & $\begin{array}{c}\text { Lost or Restricted } \\
\text { Workday Case } \\
\text { Inden }\end{array}$ \\
\hline \hline All Strain/Sprain & 2 & 2.13 & 0 & 0 \\
\hline $\begin{array}{c}\text { Cumulative Trauma } \\
\text { Disorder }\end{array}$ & 0 & 0 & 0 & 0 \\
\hline All Other & 3 & 3.19 & 1 & 1.06 \\
\hline
\end{tabular}




\subsubsection{Transition Projects (TRP)}

The numbers in Tables 2-7 and 2-8 reflect the job-related injuries/illnesses reported by TRP personnel during CY 1995 through the first quarter.

Transition Projects recorded the biggest percentage reduction in lost workday away severity rate of any group in the company (29.98 in CY 1994 to 0.74 for first quarter CY 1995).

Two of every five injuries to TRP employees during the first quarter were due to employees bumping into objects as they walked past. This may indicate a general awareness lapse within the group.

Table 2-7. TRP Occupational Injury/lllness

CY 1994 - CY 1995 Statistics Comparison

\begin{tabular}{|c|c|c|c|c|}
\hline Time Period & $\begin{array}{c}\text { First Aid } \\
\text { Cases }\end{array}$ & $\begin{array}{c}\text { First Aid } \\
\text { Case Rate }\end{array}$ & $\begin{array}{c}\text { Total } \\
\text { Recordable Cases }\end{array}$ & $\begin{array}{c}\text { Total Recordable } \\
\text { Case Incidence Rate }\end{array}$ \\
\hline \hline CY 1994 & 170 & 9.90 & 75 & 4.37 \\
\hline 1st Qtr 1994 & 58 & 11.88 & 16 & 3.28 \\
\hline 1st Qtr 1995 & 44 & 10.92 & 10 & 2.48 \\
\hline
\end{tabular}

\begin{tabular}{|c|c|c|c|c|c|c|}
\hline Time Period & $\begin{array}{c}\text { Recordable } \\
\text { Cases } \\
\text { Resulting in } \\
\text { Lost/Restricted } \\
\text { Workdays }\end{array}$ & $\begin{array}{c}\text { Lost/ } \\
\text { Restricted } \\
\text { Workday } \\
\text { Case } \\
\text { Incidence } \\
\text { Rate }\end{array}$ & $\begin{array}{c}\text { Cases } \\
\text { Involving } \\
\text { Days Away } \\
\text { from Work }\end{array}$ & $\begin{array}{c}\text { Lost Workday } \\
\text { Away Only } \\
\text { Case Incidence } \\
\text { Rate } \\
\text { Involving Days } \\
\text { of Restricted } \\
\text { Work Activity } \\
\text { Only }\end{array}$ & $\begin{array}{c}\text { Restricted } \\
\text { Work } \\
\text { Activity } \\
\text { Only Case } \\
\text { Incidence } \\
\text { Rate }\end{array}$ \\
\hline \hline CY 1994 & 26 & 1.51 & 18 & 1.05 & 8 & 0.47 \\
\hline 1st Qtr 1994 & 6 & 1.23 & 4 & 0.82 & 2 & 0.41 \\
\hline 1st Qtr 1995 & 1 & 0.25 & 1 & 0.25 & 0 & 0 \\
\hline
\end{tabular}

\begin{tabular}{|c|c|c|c|c|c|c|}
\hline Time Period & $\begin{array}{c}\text { No. of } \\
\text { Lost/ } \\
\text { Restricted } \\
\text { Workdays }\end{array}$ & $\begin{array}{c}\text { Lost/ } \\
\text { Restricted } \\
\text { Workday } \\
\text { Severity Rate }\end{array}$ & $\begin{array}{c}\text { No. of } \\
\text { Workdays } \\
\text { Away Only }\end{array}$ & $\begin{array}{c}\text { Workdays } \\
\text { Away Only } \\
\text { Severity } \\
\text { Rate }\end{array}$ & $\begin{array}{c}\text { No. of Days } \\
\text { Restricted } \\
\text { Work Activity }\end{array}$ & $\begin{array}{c}\text { Restricted } \\
\text { Work Activity } \\
\text { Severity } \\
\text { Rate }\end{array}$ \\
\hline \hline CY 1994 & 1,604 & 93.37 & 515 & 29.98 & 1,089 & 63.39 \\
\hline 1st Qtr 1994 & 514 & 105.31 & 73 & 14.96 & 441 & 90.35 \\
\hline 1st Qtr 1995 & -3 & 0.74 & 3 & 0.74 & 0 & 0 \\
\hline
\end{tabular}


Table 2-8. TRP Occupational Injuries/Illnesses By Type - 1st Qtr. 1995

\begin{tabular}{|c|c|c|c|c|}
\hline Type & $\begin{array}{c}\text { All Cases } \\
\text { (First Aid/ } \\
\text { Recordable/ } \\
\text { Lost/Restricted) }\end{array}$ & All Case Rate & $\begin{array}{c}\text { Cases Resulting } \\
\text { in Lost or } \\
\text { Restricted Workdays }\end{array}$ & $\begin{array}{c}\text { Lost or Restricted } \\
\text { Workday Case. } \\
\text { Incidence Rate }\end{array}$ \\
\hline \hline All Strain/Sprain & 13 & 3.23 & 1 & 0.25 \\
\hline Cumulative Traums Disorder & 3 & 0.74 & 0 & 0 \\
\hline All Other & 38 & 9.43 & 0 & 0 \\
\hline
\end{tabular}

\subsubsection{Spent Nuclear Fuel Project (SNF)}

The numbers in Tables 2-9 and 2-10 reflect the job-related injuries/illnesses reported by SNF personnel during CY 1995 through the first quarter.

Spent Nuclear Fuel Project saw an overall rise in injury rates, which was the only such reversal from CY 1994 to the first quarter of CY 1995. This rise shows also in the lost workday away case and severity rate. Injury cause is distributed among several common types, with strain/sprain accounting for one in three cases.

Table 2-9. SINF Occupational Injury/lllness

CY 1994 - CY 1995 Statistics Comparison

\begin{tabular}{|c|c|c|c|c|}
\hline Time Period & $\begin{array}{c}\text { First Aid } \\
\text { Cases }\end{array}$ & $\begin{array}{c}\text { First Aid } \\
\text { Case Rate }\end{array}$ & $\begin{array}{c}\text { Total } \\
\text { Recordable Cases }\end{array}$ & $\begin{array}{c}\text { Total Recordable } \\
\text { Case Incidence Rate }\end{array}$ \\
\hline \hline CY 1994 & 22 & 9.17 & 11 & 4.58 \\
\hline 1st Qtr 1994 & 2 & 5.37 & 2 & 5.37 \\
\hline 1st Qtr 1995 & 12 & 16.62 & 1 & 1.38 \\
\hline
\end{tabular}

\begin{tabular}{|c|c|c|c|c|c|c|}
\hline Time Period & $\begin{array}{c}\text { Recordable } \\
\text { Cases } \\
\text { Resulting in } \\
\text { Lost/Restricted } \\
\text { Workdays }\end{array}$ & $\begin{array}{c}\text { Lost/ } \\
\text { Restricted } \\
\text { Workday } \\
\text { Case Incidence } \\
\text { Rate }\end{array}$ & $\begin{array}{c}\text { Cases } \\
\text { Involving } \\
\text { Days Away } \\
\text { from Work }\end{array}$ & $\begin{array}{c}\text { Lost Workday } \\
\text { Away Only } \\
\text { Case Incidence } \\
\text { Rate }\end{array}$ & $\begin{array}{c}\text { Cases } \\
\text { Involving } \\
\text { Days of } \\
\text { Restricted } \\
\text { Work Activity } \\
\text { Only }\end{array}$ & $\begin{array}{c}\text { Restricted } \\
\text { Workday } \\
\text { Activity } \\
\text { Only Case } \\
\text { Incidence Rate }\end{array}$ \\
\hline \hline CY 1994 & 1 & 0.40 & 1 & 0.40 & 0 & 0 \\
\hline 1st Qtr 1994 & 0 & 0 & 0 & 0 & 0 & 0 \\
\hline 1st Qtr 1995 & 1 & 1.38 & 1 & 1.38 & 0 & 0 \\
\hline
\end{tabular}

\begin{tabular}{|c|c|c|c|c|c|c|}
\hline Time Period & $\begin{array}{c}\text { No. of } \\
\text { Lost/ } \\
\text { Restricted } \\
\text { Workdays }\end{array}$ & $\begin{array}{c}\text { Lost/ } \\
\text { Restricted } \\
\text { Workday } \\
\text { Severity Rate }\end{array}$ & $\begin{array}{c}\text { No. of } \\
\text { Workdays } \\
\text { Awray Only }\end{array}$ & $\begin{array}{c}\text { Workdays } \\
\text { Away Only } \\
\text { Severity } \\
\text { Rate }\end{array}$ & $\begin{array}{c}\text { No. of } \\
\text { Days } \\
\text { Restricted } \\
\text { Work Activity }\end{array}$ & $\begin{array}{c}\text { Restricted } \\
\text { Work Activity } \\
\text { Severity } \\
\text { Rate }\end{array}$ \\
\hline \hline CY 1994 & 2 & 0.80 & 2 & 0.80 & 0 & 0 \\
\hline 1st Qtr 1994 & 0 & 0 & 0 & 0 & 0 & 0 \\
\hline 1st Qtr 1995 & 2 & 2.77 & 1 & 1.38 & 1 & 1.38 \\
\hline
\end{tabular}


Table 2-10. SNF Occupational Injuries/Illnesses By Type - 1st Qtr. 1995

\begin{tabular}{|c|c|c|c|c|}
\hline Type & $\begin{array}{c}\text { All Cases } \\
\text { (First Aid/ } \\
\text { Recordable/ } \\
\text { Lost/Restricted) }\end{array}$ & All Case Rate & $\begin{array}{c}\text { Cases Resulting } \\
\text { in Lost or } \\
\text { Restricted Workdays }\end{array}$ & $\begin{array}{c}\text { Lost or Restricted } \\
\text { Workday Case } \\
\text { Incidence Rate }\end{array}$ \\
\hline \hline All Strain/Sprain & 5 & 6.92 & 1 & 1.38 \\
\hline Cumulative Trauma Disorder & 0 & 0 & 0 & 0 \\
\hline All Other & 8 & 11.08 & 0 & 0 \\
\hline
\end{tabular}

\subsubsection{Emergency, Safety, Quality Services (ESQ).}

The numbers in Tables 2-11 and 2-12 reflect the job-related injuries/illnesses reported by ESQ personinel during CY 1995 through the first quarter.

Emergency, Safety, Quality Services shows exceptionally strong performance in reduction of disabling case and severity rates. Lost workday away case rates were lowered by over 70 percent, and the workdays away severity rate was lowered by over 90 percent from CY 1994.

The ESQ department has seen several recent injuries caused by questionable training methods and incomplete planning.

Table 2-11. ESQ Occupational Injury/lliness

CY 1994 - CY 1995 Statistics Comparison

\begin{tabular}{|c|c|c|c|c|}
\hline Time Period & $\begin{array}{c}\text { First Aid } \\
\text { Only Cases }\end{array}$ & $\begin{array}{c}\text { First Aid } \\
\text { Case Rate }\end{array}$ & $\begin{array}{c}\text { Total } \\
\text { Recordable Cases }\end{array}$ & $\begin{array}{c}\text { Total Recordable } \\
\text { Case Incidence Rate }\end{array}$ \\
\hline \hline CY 1994 & 185 & 11.16 & 81 & 4.89 \\
\hline 1st Qtr 1994 & 43 & 9.55 & 20 & 4.44 \\
\hline 1st Qtr 1995 & 36 & 8.96 & 18 & 4.48 \\
\hline
\end{tabular}

\begin{tabular}{|c|c|c|c|c|c|c|}
\hline Time Period & $\begin{array}{c}\text { Recordable } \\
\text { Cases } \\
\text { Resulting in } \\
\text { Lost/Restricted } \\
\text { Workdays }\end{array}$ & $\begin{array}{c}\text { Lost/ } \\
\text { Restricted } \\
\text { Workday } \\
\text { Case } \\
\text { Incidence } \\
\text { Rate }\end{array}$ & $\begin{array}{c}\text { Cases } \\
\text { Involving } \\
\text { Days Away } \\
\text { from Work }\end{array}$ & $\begin{array}{c}\text { Lost Workday } \\
\text { Away Only } \\
\text { Case } \\
\text { Incidence } \\
\text { Rate }\end{array}$ & $\begin{array}{c}\text { Cases } \\
\text { Involving } \\
\text { Days of } \\
\text { Restricted } \\
\text { Work Activity } \\
\text { Only }\end{array}$ & $\begin{array}{c}\text { Restricted } \\
\text { Work } \\
\text { Activity } \\
\text { Only Case } \\
\text { Incidence } \\
\text { Rate }\end{array}$ \\
\hline \hline CY 1994 & 29 & 1.75 & 15 & 0.90 & 14 & 0.84 \\
\hline 1st Qtr 1994 & 6 & 1.33 & 4 & 0.89 & 2 & 0.44 \\
\hline 1st Qtr 1995 & 11 & 2.74 & 1 & 0.25 & 10 & 2.49 \\
\hline
\end{tabular}

\begin{tabular}{|c|c|c|c|c|c|c|}
\hline Time Period & $\begin{array}{c}\text { No. of } \\
\text { Lost/ } \\
\text { Restricted } \\
\text { Workdays }\end{array}$ & $\begin{array}{c}\text { Lost/ } \\
\text { Restricted } \\
\text { Workday } \\
\text { Severity Rate }\end{array}$ & $\begin{array}{c}\text { No. of } \\
\text { Workdays } \\
\text { Away Only }\end{array}$ & $\begin{array}{c}\text { Workdays } \\
\text { Away Only } \\
\text { Severity } \\
\text { Rate }\end{array}$ & $\begin{array}{c}\text { No. of } \\
\text { Days } \\
\text { Restricted } \\
\text { Work Activity }\end{array}$ & $\begin{array}{c}\text { Restricted } \\
\text { Work Activity } \\
\text { Severity } \\
\text { Rate }\end{array}$ \\
\hline \hline CY 1994 & 905 & 54.59 & 373 & 22.50 & 532 & 32.09 \\
\hline 1st Qtr 1994 & 168 & 37.32 & 102 & 22.66 & 66 & 14.66 \\
\hline 1st Qtr 1995 & 127 & 31.62 & 6 & 1.49 & 121 & 30.13 \\
\hline
\end{tabular}


Table 2-12. ESQ Occupational Injuries/lllnesses By Type - 1st Qtr. 1995

\begin{tabular}{|c|c|c|c|c|}
\hline Type & $\begin{array}{c}\text { All Cases } \\
\text { (First Aid/ } \\
\text { Recordable/ } \\
\text { Lost/Restricted) }\end{array}$ & All Case Rate & $\begin{array}{c}\text { Cases Resulting } \\
\text { in Lost or } \\
\text { Restricted Workdays }\end{array}$ & $\begin{array}{c}\text { Lost or Restricted } \\
\text { Workday Case } \\
\text { Incidence Rate }\end{array}$ \\
\hline \hline All Strain/Sprain & 20 & 4.98 & 8 & 1.99 \\
\hline Cumulative Trauma Disorder & 1 & 0.25 & 0 & 0 \\
\hline All Other & 33 & 8.22 & 3 & 0.75 \\
\hline
\end{tabular}

\subsubsection{Administration (ADM)}

The numbers in Tables 2-13 and 2-14 reflect the job-related injuries/illnesses reported by ADM personnel during CY 1995 through the first quarter.

Administration saw a rise in both the frequency and severity of lost workday cases from the previous twelve months. Relatively low work hour totals contribute to the apparent.sharp rise in these rates. Total overall injuries were lowered by some 20 percent.

Table 2-13. ADM Occupational Injury/lllness

CY 1994 - CY 1995 Statistics Comparison

\begin{tabular}{|c|c|c|c|c|}
\hline Time Period & $\begin{array}{c}\text { First Aid } \\
\text { Cases }\end{array}$ & $\begin{array}{c}\text { First Aid } \\
\text { Case Rate }\end{array}$ & $\begin{array}{c}\text { Total } \\
\text { Recordable Cases }\end{array}$ & $\begin{array}{c}\text { Total Recordable } \\
\text { Case Incidence Rate }\end{array}$ \\
\hline \hline CY 1994 & 19 & 4.19 & 20 & 4.41 \\
\hline 1st Qtr 1994 & 5 & 4.85 & 6 & 5.82 \\
\hline 1st Qtr 1995 & 5 & 3.38 & 1 & 0.68 \\
\hline
\end{tabular}

\begin{tabular}{|c|c|c|c|c|c|c|}
\hline Time Period & $\begin{array}{c}\text { Recordable } \\
\text { Cases } \\
\text { Resulting in } \\
\text { Lost/Restricted } \\
\text { Workdays }\end{array}$ & $\begin{array}{c}\text { Lost/ } \\
\text { Restricted } \\
\text { Workday } \\
\text { Case } \\
\text { Incidence } \\
\text { Rate }\end{array}$ & $\begin{array}{c}\text { Cases } \\
\text { Involving } \\
\text { Days Away } \\
\text { from Work }\end{array}$ & $\begin{array}{c}\text { Lost Workday } \\
\text { Away Only } \\
\text { Case Incidence } \\
\text { Rate }\end{array}$ & $\begin{array}{c}\text { Cases } \\
\text { Involving } \\
\text { Days of } \\
\text { Restricted } \\
\text { Work Activity } \\
\text { Only }\end{array}$ & $\begin{array}{c}\text { Restricted } \\
\text { Work } \\
\text { Activity } \\
\text { Only Case } \\
\text { Incidence } \\
\text { Rate }\end{array}$ \\
\hline \hline CY 1994 & 4 & 0.88 & 2 & 0.44 & 2 & 0.44 \\
\hline 1st Qtr 1994 & 2 & 1.94 & 2 & 1.94 & 0 & 0 \\
\hline 1st Qtr 1995 & 1 & 0.68 & 1 & 0.68 & 0 & 0 \\
\hline
\end{tabular}

\begin{tabular}{|c|c|c|c|c|c|c|}
\hline Time Period & $\begin{array}{c}\text { No. of } \\
\text { Lost/ } \\
\text { Restricted } \\
\text { Workdays }\end{array}$ & $\begin{array}{c}\text { Lost/ } \\
\text { Restricted } \\
\text { Days } \\
\text { Severity } \\
\text { Rate }\end{array}$ & $\begin{array}{c}\text { No. of } \\
\text { Workdays } \\
\text { Away Only }\end{array}$ & $\begin{array}{c}\text { Workdays } \\
\text { Away Only } \\
\text { Severity } \\
\text { Rate }\end{array}$ & $\begin{array}{c}\text { No. of } \\
\text { Days } \\
\text { Restricted } \\
\text { Work Activity }\end{array}$ & $\begin{array}{c}\text { Restricted } \\
\text { Work Activity } \\
\text { Severity } \\
\text { Rate }\end{array}$ \\
\hline \hline CY 1994 & 149 & 32.84 & 69 & 15.21 & 80 & 17.63 \\
\hline 1st Qtr 1994 & 82 & 79.59 & 69 & 66.97 & 13 & 12.62 \\
\hline 1st Qtr 1995 & 41 & 27.68 & 41 & 27.68 & 0 & 0 \\
\hline
\end{tabular}


Table 2-14. ADM Occupational Injuries/Illnesses By Type - 1st Qtr. 1995

\begin{tabular}{|c|c|c|c|c|}
\hline Type & $\begin{array}{c}\text { All Cases } \\
\text { (First Aid/ } \\
\text { Recordable/ } \\
\text { Lost/Restricted) }\end{array}$ & All Case Rate & $\begin{array}{c}\text { Cases Resulting } \\
\text { in Lost or } \\
\text { Restricted Workdays }\end{array}$ & $\begin{array}{c}\text { Lost or Restricted } \\
\text { Workday Case } \\
\text { Incidence Rate }\end{array}$ \\
\hline \hline All Strain/Sprain & 3 & 2.03 & 1 & 0.68 \\
\hline Cumulative Trauma Disorder & 0 & 0 & 0 & 0 \\
\hline All Other & 3 & 2.03 & 0 & 0 \\
\hline
\end{tabular}

\subsubsection{BCSR.}

The numbers in Tables 2-15 and 2-16 reflect the job-related injuries/illnesses reported by BCSR personnel during CY 1995 through the first quarter.

The BCSR department posted first quarter injury rates which were reduced from the previous calendar year rates across the board. The most impressive reduction is in the lost workday away severity rate category, which showed a 88 percent reduction. Two-thirds of injuries suffered by BCSR employees were to the hand/finger area.

Table 2-15. BCSR Occupational Injury/lllness

CY 1994 - CY 1995 Statistics Comparison

\begin{tabular}{|c|c|c|c|c|}
\hline Time Period & $\begin{array}{c}\text { First Aid } \\
\text { Cases }\end{array}$ & $\begin{array}{c}\text { First Aid } \\
\text { Case Rate }\end{array}$ & $\begin{array}{c}\text { Total } \\
\text { Recordable Cases }\end{array}$ & $\begin{array}{c}\text { Total Recordable } \\
\text { Case Incidence Rate }\end{array}$ \\
\hline \hline CY 1994 & 80 & 6.98 & 53 & 4.62 \\
\hline 1st Qtr 1994 & 26 & 8.82 & 18 & 6.11 \\
\hline 1st Qtr 1995 & 18 & 6.82 & 10 & 3.79 \\
\hline
\end{tabular}

\begin{tabular}{|c|c|c|c|c|c|c|}
\hline Time Period & $\begin{array}{c}\text { Recordable } \\
\text { Cases } \\
\text { Resulting in } \\
\text { Lost/Restricted } \\
\text { Workdays }\end{array}$ & $\begin{array}{c}\text { Lost/ } \\
\text { Restricted } \\
\text { Workday } \\
\text { Case } \\
\text { Incidence } \\
\text { Rate }\end{array}$ & $\begin{array}{c}\text { Cases } \\
\text { Involving } \\
\text { Days Away } \\
\text { from Work }\end{array}$ & $\begin{array}{c}\text { Lost Workday } \\
\text { Away Only } \\
\text { Case Incidence } \\
\text { Rate }\end{array}$ & $\begin{array}{c}\text { Cases } \\
\text { Involving } \\
\text { Days of } \\
\text { Restricted } \\
\text { Work Activity } \\
\text { Only }\end{array}$ & $\begin{array}{c}\text { Restricted } \\
\text { Work } \\
\text { Activity } \\
\text { Only Case } \\
\text { Incidence } \\
\text { Rate }\end{array}$ \\
\hline \hline CY 1994 & 13 & 1.13 & 8 & 0.70 & 5 & 0.44 \\
\hline 1st Qtr 1994 & 4 & 1.36 & .3 & 1.02 & 1 & 0.34 \\
\hline 1st Qtr 1995 & 2 & 0.76 & 1 & 0.38 & 1 & 0.38 \\
\hline
\end{tabular}

\begin{tabular}{|c|c|c|c|c|c|c|}
\hline Time Period & $\begin{array}{c}\text { No. of } \\
\text { Lost/ } \\
\text { Restricted } \\
\text { Workdays }\end{array}$ & $\begin{array}{c}\text { Lost/ } \\
\text { Restricted } \\
\text { Workday } \\
\text { Severity Rate }\end{array}$ & $\begin{array}{c}\text { No. of } \\
\text { Workdays } \\
\text { Away Only }\end{array}$ & $\begin{array}{c}\text { Workdays } \\
\text { Away Only } \\
\text { Severity } \\
\text { Rate }\end{array}$ & $\begin{array}{c}\text { No. of } \\
\text { Days } \\
\text { Restricted } \\
\text { Work Activity }\end{array}$ & $\begin{array}{c}\text { Restricted } \\
\text { Work Activity } \\
\text { Severity } \\
\text { Rate }\end{array}$ \\
\hline \hline CY 1994 & 289 & 25.20 & 146 & 12.73 & 143 & 12.47 \\
\hline 1st Qtr 1994 & 118 & 40.02 & 70 & 23.74 & 48 & 16.28 \\
\hline 1st Qtr 1995 & 40 & 15.16 & 4 & 1.52 & 36 & 13.65 \\
\hline
\end{tabular}


Table 2-16. BCSR Occupational Injuries/lllnesses By Type - 1st Qtr. 1995

\begin{tabular}{|c|c|c|c|c|}
\hline Type & $\begin{array}{c}\text { All Cases } \\
\text { (First Aid/ } \\
\text { Recordable/ } \\
\text { Lost/Restricted) }\end{array}$ & All Case Rate & $\begin{array}{c}\text { Cases Resulting } \\
\text { in Lost or } \\
\text { Restricted Workdays }\end{array}$ & $\begin{array}{c}\text { Lost or Restricted } \\
\text { Workday Case } \\
\text { Incidence Rate }\end{array}$ \\
\hline \hline All Strain/Sprain & 7 & 2.65 & 1 & 0.38 \\
\hline Cumulative Traums Disorder & 4 & 1.52 & 1 & 0.38 \\
\hline All Other & 17 & 6.45 & 0 & 0 \\
\hline
\end{tabular}

\subsubsection{Tank Waste Remediation Systems (TWR).}

The numbers in Tables 2-17 and 2-18 reflect the job-related injuries/illnesses reported by TWR personnel during CY 1995 through the first quarter.

Tank Waste Remediation Systems reduced first aid cases by near 20 percent, lost workday away cases by 50 percent, and workdays away due to injury by over 90 percent.

Table 2-17. TWR Dept. Occupational Injury/lliness

CY 1994 - CY 1995 Statistics Comparison

\begin{tabular}{|c|c|c|c|c|}
\hline Time Period & $\begin{array}{c}\text { First Aid } \\
\text { Cases }\end{array}$ & $\begin{array}{c}\text { First Aid } \\
\text { Case Rate }\end{array}$ & $\begin{array}{c}\text { Total } \\
\text { Recordable Cases }\end{array}$ & $\begin{array}{c}\text { Total Recordable } \\
\text { Case Incidence Rate }\end{array}$ \\
\hline \hline CY 1994 & 114 & 6.90 & 55 & 3.33 \\
\hline 1st Qtr 1994 & 22 & 5.98 & 10 & 2.72 \\
\hline 1st Qtr 1995 & 22 & 5.61 & 12 & 3.06 \\
\hline
\end{tabular}

\begin{tabular}{|c|c|c|c|c|c|c|}
\hline Time Period & $\begin{array}{c}\text { Recordable Cases } \\
\text { Resulting in } \\
\text { Lost/Restricted } \\
\text { Workdays }\end{array}$ & $\begin{array}{c}\text { Lost/ } \\
\text { Restricted } \\
\text { Workclay } \\
\text { Case } \\
\text { Incidence } \\
\text { Rate }\end{array}$ & $\begin{array}{c}\text { Cases } \\
\text { Involving } \\
\text { Days Away } \\
\text { from Work }\end{array}$ & $\begin{array}{c}\text { Lost } \\
\text { Workday } \\
\text { Away Only } \\
\text { Case Incidence } \\
\text { Rate }\end{array}$ & $\begin{array}{c}\text { Cases } \\
\text { Involving } \\
\text { Days of } \\
\text { Restricted } \\
\text { Work Activity } \\
\text { Only }\end{array}$ & $\begin{array}{c}\text { Restricted } \\
\text { Work } \\
\text { Activity } \\
\text { Only Case } \\
\text { Incidence } \\
\text { Rate }\end{array}$ \\
\hline \hline CY 1994 & 15 & 0.91 & 9 & 0.54 & 6 & 0.36 \\
\hline 1st Qtr 1994 & 0 & 0 & 0 & 0 & 0 & 0 \\
\hline 1st Qtr 1995 & 4 & 1.02 & 1 & 0.25 & 3 & 0.76 \\
\hline
\end{tabular}

\begin{tabular}{|c|c|c|c|c|c|c|}
\hline Time Period & $\begin{array}{c}\text { No. of } \\
\text { Lost/ } \\
\text { Restricted } \\
\text { Workdays }\end{array}$ & $\begin{array}{c}\text { Lost/ } \\
\text { Restricted } \\
\text { Workday } \\
\text { Severity } \\
\text { Rate }\end{array}$ & $\begin{array}{c}\text { No. of } \\
\text { Workdays } \\
\text { Away Only }\end{array}$ & $\begin{array}{c}\text { Workdays } \\
\text { Away Only } \\
\text { Severity } \\
\text { Rate }\end{array}$ & $\begin{array}{c}\text { No. of Days } \\
\text { Restricted } \\
\text { Work Activity }\end{array}$ & $\begin{array}{c}\text { Restricted } \\
\text { Work Activity } \\
\text { Severity } \\
\text { Rate }\end{array}$ \\
\hline \hline CY 1994 & 298 & 18.04 & 73 & 4.42 & 225 & 13.62 \\
\hline 1st Qtr 1994 & 0 & 0 & 0 & 0 & 0 & 0 \\
\hline 1st Qtr 1995 & 63 & 16.05 & 1 & 0.25 & 62 & 15.80 \\
\hline
\end{tabular}


Table 2-18. TWR Occupational Injuries/Illnesses By Type - 1st Qtr. 1995

\begin{tabular}{|c|c|c|c|c|}
\hline Type & $\begin{array}{c}\text { All Cases } \\
\text { (First Aid/ } \\
\text { Recordable/ } \\
\text { Lost/Restricted) }\end{array}$ & All Case Rate & $\begin{array}{c}\text { Cases Resulting } \\
\text { in Lost or } \\
\text { Restricted Workdays }\end{array}$ & $\begin{array}{c}\text { Lost or Restricted } \\
\text { Workday Case } \\
\text {.Incidence Rate }\end{array}$ \\
\hline \hline All Strain/Sprain & 9 & 2.29 & 3 & 0.76 \\
\hline Cumulative Trauma Disorder & 3 & 0.76 & 0 & 0 \\
\hline All Other & 22 & 5.61 & 1 & 0.25 \\
\hline
\end{tabular}

\subsubsection{Projected Site Services (PSS)}

The numbers in Tables 2-19 and 2-20 reflect the job-related injuries/illnesses reported by PSS personnel during CY 1995 through the first quarter.

Projected Site Services completed the first quarter without recording a lost workday away injury. A twenty percent rise in first aid case rates can be traced to awareness lapses, such as bumping into stationary objects in the workplace and tripping on stairways.

Table 2-19. PSS-Dept. Occupational Injury/Illness

CY 1994 - CY 1995 Statistics Comparison

\begin{tabular}{|c|c|c|c|c|}
\hline Time Period & $\begin{array}{c}\text { First Aid } \\
\text { Cases }\end{array}$ & $\begin{array}{c}\text { First Aid } \\
\text { Case Rate }\end{array}$ & $\begin{array}{c}\text { Total } \\
\text { Recordable Cases }\end{array}$ & $\begin{array}{c}\text { Total Recordable } \\
\text { Case Incidence Rate }\end{array}$ \\
\hline \hline CY 1994 & 78 & 5.98 & 44 & 3.38 \\
\hline 1st Qtr 1994 & 8 & 3.23 & 5 & 2.02 \\
\hline 1st Qtr 1995 & 12 & 4.81 & 7 & 2.81 \\
\hline
\end{tabular}

\begin{tabular}{|c|c|c|c|c|c|c|}
\hline Time Period & $\begin{array}{c}\text { Recordable } \\
\text { Cases } \\
\text { Resulting in } \\
\text { Lost/Restricted } \\
\text { Workdays }\end{array}$ & $\begin{array}{c}\text { Lost/ } \\
\text { Restricted } \\
\text { Workday } \\
\text { Case } \\
\text { Incidence } \\
\text { Rate }\end{array}$ & $\begin{array}{c}\text { Cases } \\
\text { Involving } \\
\text { Days Away } \\
\text { from Work }\end{array}$ & $\begin{array}{c}\text { Lost } \\
\text { Workday } \\
\text { Away Only } \\
\text { Case } \\
\text { Incidence } \\
\text { Rate }\end{array}$ & $\begin{array}{c}\text { Cases } \\
\text { Involving } \\
\text { Days of } \\
\text { Restricted } \\
\text { Work Activity } \\
\text { Only }\end{array}$ & $\begin{array}{c}\text { Restricted } \\
\text { Work } \\
\text { Activity } \\
\text { Onty Case } \\
\text { Incidence Rate }\end{array}$ \\
\hline \hline CY 1994 & 11 & 0.84 & 7 & 0.54 & 4 & 0.31 \\
\hline 1st Qtr 1994 & 2 & 0.81 & 0 & 0 & 2 & 0.81 \\
\hline 1st Qtr 1995 & 3 & 1.20 & 0 & 0 & 3 & 1.20 \\
\hline
\end{tabular}

\begin{tabular}{|c|c|c|c|c|c|c|}
\hline Time Period & $\begin{array}{c}\text { No. of } \\
\text { Lost/ } \\
\text { Restricted } \\
\text { Workdays }\end{array}$ & $\begin{array}{c}\text { Lost/ } \\
\text { Restricted } \\
\text { Workday } \\
\text { Severity Rate }\end{array}$ & $\begin{array}{c}\text { No. of } \\
\text { Workdays } \\
\text { Away Only }\end{array}$ & $\begin{array}{c}\text { Workdays } \\
\text { Away Only } \\
\text { Severity } \\
\text { Rate }\end{array}$ & $\begin{array}{c}\text { No. of } \\
\text { Days } \\
\text { Restricted } \\
\text { Work Activity }\end{array}$ & $\begin{array}{c}\text { Restricted } \\
\text { Work Activity } \\
\text { Severity } \\
\text { Rate }\end{array}$ \\
\hline \hline CY 1994 & 367 & 28.16 & 93 & 7.14 & 274 & 21.02 \\
\hline 1st Qtr 1994 & 95 & 38.36 & 0 & 0 & 95 & 38.36 \\
\hline 1st Qtr 1995 & 10 & 4.01 & 0 & 0 & 10 & 4.01 \\
\hline
\end{tabular}


Table 2-20. PSS Occupational Injuries/lllnesses By Type - 1st Qtr. 1995

\begin{tabular}{|c|c|c|c|c|}
\hline Type & $\begin{array}{c}\text { All Cases } \\
\text { (First Aid/ } \\
\text { Recordable/ } \\
\text { Lost/Restricted) }\end{array}$ & All Case Rate & $\begin{array}{c}\text { Cases Resulting } \\
\text { in Lost or } \\
\text { Restricted Workdays }\end{array}$ & $\begin{array}{c}\text { Lost or Restricted } \\
\text { Workday Case } \\
\text { Incidence Rate }\end{array}$ \\
\hline \hline All Strain/Sprain & 7 & 2.81 & 2 & 0.80 \\
\hline Cumulative Trauma Disorder & 1 & 0.40 & 0 & 0 \\
\hline All Other & 11 & 4.41 & 1 & 0.40 \\
\hline
\end{tabular}

\subsubsection{Solid Waste Disposal (SWD)}

The numbers in Tables 2-21 and 2-22 reflect the job-related injuries/illnesses reported by SWD personnel during CY 1995 through the first quarter.

Solid Waste Disposal successfully managed strain injuries to keep any from escalating to lost workday level. The increase in first aid case rates is, however, due primarily to strains which occurred as the employee slipped or contorted the body in an unusual manner.

Table 2-21. SWD Occupational Injury/IIlness

CY 1994 - CY 1995 Statistics Comparison

\begin{tabular}{|c|c|c|c|c|}
\hline Time Period & $\begin{array}{c}\text { First Aid } \\
\text { Cases }\end{array}$ & $\begin{array}{c}\text { First Aid } \\
\text { Case Rate }\end{array}$ & $\begin{array}{c}\text { Total } \\
\text { Recordable Cases }\end{array}$ & $\begin{array}{c}\text { Total Recordable } \\
\text { Case Incidence Rate }\end{array}$ \\
\hline \hline CY 1994 & 44 & 11.85 & 22 & 5.93 \\
\hline 1st Qtr 1994 & 8 & 4.43 & 6 & 6.65 \\
\hline 1st Qtr 1995 & 6 & 6.35 & 4 & 4.23 \\
\hline
\end{tabular}

\begin{tabular}{|c|c|c|c|c|c|c|}
\hline Time Period & $\begin{array}{c}\text { Recordable } \\
\text { Cases } \\
\text { Resulting in } \\
\text { Lost/Restricted } \\
\text { Workdays }\end{array}$ & $\begin{array}{c}\text { Lost/ } \\
\text { Restricted } \\
\text { Workday } \\
\text { Case } \\
\text { Incidence } \\
\text { Rate }\end{array}$ & $\begin{array}{c}\text { Cases } \\
\text { Involving } \\
\text { Days Away } \\
\text { from Work }\end{array}$ & $\begin{array}{c}\text { Lost } \\
\text { Workday } \\
\text { Away Only } \\
\text { Case } \\
\text { Incidence } \\
\text { Rate }\end{array}$ & $\begin{array}{c}\text { Cases } \\
\text { Involving } \\
\text { Days of } \\
\text { Restricted } \\
\text { Work Activity } \\
\text { Only }\end{array}$ & $\begin{array}{c}\text { Restricted } \\
\text { Work } \\
\text { Activity } \\
\text { Only Case } \\
\text { Incidence Rate }\end{array}$ \\
\hline \hline CY 1994 & 7 & 1.89 & 3 & 0.81 & 4 & 1.08 \\
\hline 1st Qtr 1994 & 2 & 2.22 & 2 & 2.22 & 0 & 0 \\
\hline 1st Qtr 1995 & 0 & 0 & 0 & 0 & 0 & 0 \\
\hline
\end{tabular}

\begin{tabular}{|c|c|c|c|c|c|c|}
\hline Time Period & $\begin{array}{c}\text { No. of } \\
\text { Lost/ } \\
\text { Restricted } \\
\text { Workdays }\end{array}$ & $\begin{array}{c}\text { Lost/ } \\
\text { Restricted } \\
\text { Workday } \\
\text { Severity Rate }\end{array}$ & $\begin{array}{c}\text { No. of } \\
\text { Workdays } \\
\text { Away Only }\end{array}$ & $\begin{array}{c}\text { Workdays } \\
\text { Away Only } \\
\text { Severity } \\
\text { Rate }\end{array}$ & $\begin{array}{c}\text { No. of } \\
\text { Days } \\
\text { Restricted } \\
\text { Work Activity }\end{array}$ & $\begin{array}{c}\text { Restricted } \\
\text { Work Activity } \\
\text { Severity } \\
\text { Rate }\end{array}$ \\
\hline \hline CY 1994 & 76 & 20.47 & 14 & 3.77 & 62 & 20.47 \\
\hline 1st Qtr 1994 & 6 & 6.65 & 6 & 6.65 & 0 & 0 \\
\hline 1st Qtr 1995 & 0 & 0 & 0 & 0 & 0 & 0 \\
\hline
\end{tabular}


Table 2-22. SWD Occupational Injuries/lllnesses By Type - 1st Qtr. 1995

\begin{tabular}{|c|c|c|c|c|}
\hline Type & $\begin{array}{c}\text { All Cases } \\
\text { (First Aid/ } \\
\text { Recorddable/ } \\
\text { Lost/Restricted) }\end{array}$ & All Case Rate & $\begin{array}{c}\text { Cases Resulting } \\
\text { in Lost or } \\
\text { Restricted Workdays }\end{array}$ & $\begin{array}{c}\text { Lost or Restricted } \\
\text { Workday Case } \\
\text { Incidence Rate }\end{array}$ \\
\hline \hline All Strain/Sprain & 7 & 7.41 & 0 & 0 \\
\hline Cumulative Trauma Disorder & 0 & 0 & 0 & 0 \\
\hline All Other & 3 & 3.17 & 0 & 0 \\
\hline
\end{tabular}

\subsubsection{ICF Kaiser Hanford Company (ICF KH) Lost/Restricted Workday Cases/Rates}

By DOE Computerized Accident/Incident Reporting (CAIRS) Organization

The ICF KH cumulative CY 1995 first quarter lost/restricted workday case rate (2.54) is 37 percent below the company's 3 year average (4.05). (Figure 2-28)

The ICF KH cumulative CY 1995 first quarter lost/restricted workday incidence (severity) rate (38.02) is 68 percent below the company's 3 year average (118.45). (Figure 2-29)

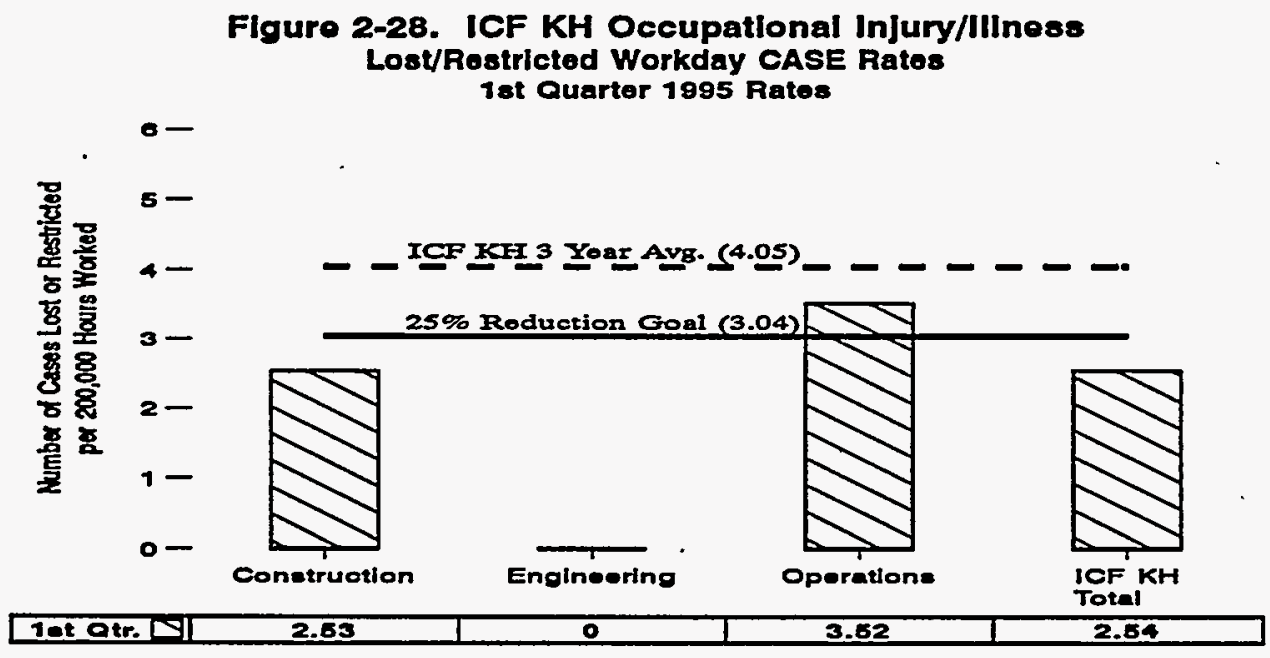

Figure 2-29. ICF KH Occupational Injury/IIIness Lost/Rostrictod Workday INCIDENCE Ratos 1st Quartor 1995 Ratos

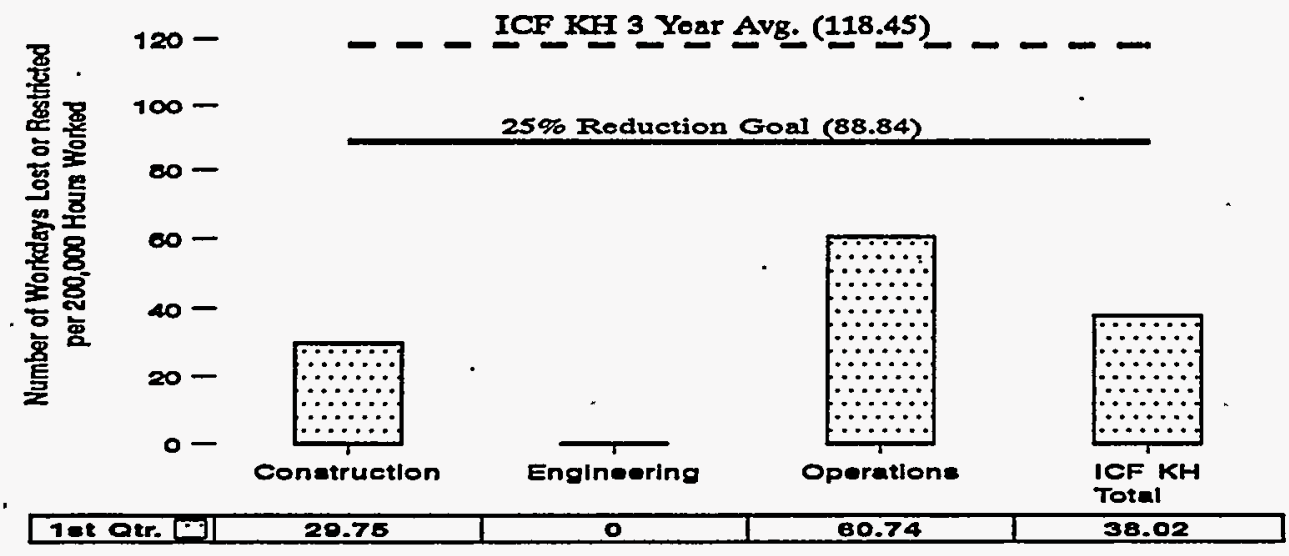




\subsubsection{WHC Recordable Government Motor Vehicle Accidents}

There were four recordable government vehicle accidents (resulting in $\$ 500$ damage or greater) reported by WHC employees during the first quarter of CY 1995, as compared to 3 recordable vehicle accidents for the same time period in CY 1994. The WHC CY 1995 through first quarter recordable government vehicle accident rate is 3.41 , which is above the company's CY 1994 through first quarter rate (1.80), and also above the DOE CY 1991-93 average of 2.60.

The WHC CY 1995 through first quarter recordable government vehicle dollar loss rate (from the recordable vehicle accidents) is 13.05 , which is above the company's CY 1994 through first quarter rate (2.48), and also above DOE CY $1991-93$ average of 4.17.

Tables 2-23 and 2-24 provide a breakdown of the recordable government vehicle accidents by organization, and type of accident. Refer to Appendix B-2 for a complete description of the first quarter losses.

\begin{tabular}{|c|l|c|c|}
\hline \multicolumn{2}{|c|}{ Table 2-23. WHC CY 1995 1st Quarter - Recordable Vehicle Accidents By Organization } \\
\hline \hline $\begin{array}{c}\text { Organization } \\
\text { Code }\end{array}$ & \multicolumn{1}{|c|}{ Organization } & $\begin{array}{c}\text { Number of } \\
\text { Losses }\end{array}$ & $\begin{array}{c}\text { Total } \\
\text { Dollar Loss }\end{array}$ \\
\hline \hline $2 \mathrm{C}$ & Engineering \& Systems Integration & 1 & $\$ 7,420$ \\
\hline 33 & Health Physics & 1 & $\$ 5,527$ \\
\hline 7C & Tank Waste Remediation Operations Support & 2 & $\$ 2,343$ \\
\hline \hline \multicolumn{2}{|c|}{ WHC Total } & 4 & $\$ 15,290$ \\
\hline
\end{tabular}

Table 2-24. WHC CY 1995 1st Quarter - Recordable Vehicle Accidents By Cause of Accident

\begin{tabular}{|c|c|c|}
\hline \hline Cause of Accident & Number of Losses & Total Dollar Loss \\
\hline \hline Operator Error-Backing & 2 & $\$ 8,452$ \\
\hline Operator Error-Clearance & 0 & $\$$ \\
\hline Operator Error-Other & 2 & $\$ 6,838$ \\
\hline Non-Operator Error & 0 & $\$$ \\
\hline \hline WHC Total & 4 & $\$ 15,290$ \\
\hline
\end{tabular}




\subsection{RADIOLOGICAL SAFETY}

Radiological health and safety of the WHC and ICF KH workforce is ensured through the development and effective implementation of the radiological control program. Occupational radiation safety is the primary focus of the WHC Radiological Control Program. This section provides management with a perspective on performance of the Radiological Control organization in implementing processes that seek individual and collective doses to levels ALARA .

\subsection{RADIOLOGICAL CONTROL PROGRAM PERFORMANCE}

In this section, key performance trends and program acomplishments throughout the first quarter of CY 1995 are discussed.

\subsubsection{Key Performance Trends}

The Radiological Control program is on course to meet all RL Site Management System (SMS) milestones and program commitments, as documented in the current Site Support Program Plan, on schedule. Significant progress continues to be made in the leadership and execution of requirements associated for 10 CFR 835 implementation. Improved focus and energy on broad areas of program management, such as leadership in improving Radiological Control program efficiency, and training to improve the conduct of radiological operations and maintenance remained as areas demonstrating accomplishments. Focus continues on areas where improvement is needed, such as injury/illness rates and skin/clothing contamination events. Financial resources and cost control continued to be acceptable in nearly all areas.

\subsubsection{Program Accomplishments}

Program accomplishments are compiled monthly by the Radiological Control program and are presented during interfaces with RL and published via company reports. Some notable accomplishments are listed here.

Major programmatic accomplishments completed during this reporting period include the Department of Energy-Headquarters (DOE-HQ) formally endorsing the Radiological Control organization's approach toward development of the Radiation Protection Program (RPP) document (DOE-HQ, EM-1, Thomas Grumbly and DOE-HQ, EH-10, Keith Christopher). The DOE-HQ has recognized the significant contributions and leadership that Radiological Control has provided in planning and implementation of this "model example of an RPP" across the DOE complex and is encouraging other sites to contact WHC for assistance in developing their RPPs.

The RPP review went well, and all revisions were incorporated and submitted to RL on March 31, 1995. The strong leadership from the DOE-RL review team (Dan Rice) helped expedite this process. Facility management briefings are being conducted to ensure that compliance actions are understood. A commitment tracking system is being implemented at the company level.

In addition, WHC is coordinating with ICF KH to ensure that activities conducted at all ICF KH-operated facilities under subcontract to WHC are in full compliance with the WHC-approved RPP by January 1, 1996. 
Training to improve conduct of radiological operations was delivered to plant radiological improvement teams during March. The Radiological Control organization conducted two-day training classes for radiological workers entitled "The Radiological Team; Improving the Conduct of Radiological Operations and Maintenance." This training course provides a focus on improving radiological operations and maintenance. Plant improvement teams are being utilized in several facilities and are making progress on "teaming" efforts to improve the ownership and understanding of radiological controls.

\subsubsection{Program Status}

The Radiological Control Program experienced an overall improvement in most areas for this reporting period. This improvement is primarily led by efforts associated with the submittal of the RPP document for 10 CFR 835 implementation. The ES\&H compliance and customer performance continues to be "good" for most program elements with an improvement this month in Program Control and Integration customer relations due to open interactions and communications with RL on the RPP. The Radiological Control schedule category worsened to "marginal" in March due to not accomplishing one SMS milestone as scheduled. However, all other technical work scope commitments are being completed on time. Cost control performance is still being challenged due to overruns in department overhead and underruns in the self-liquidating dosimetry pool.

\subsubsection{Schedule (DOE-HQ/FO/RL) Status}

Nine of the 23 DOE-RL milestones for FY 1995 were accomplished by March 31, 1995. During March there were five FY 1995 milestones scheduled for completion by the Radiological Control Organization. Four RL Milestones (RAD-95-003, RAD-95-006, RAD-95-011, and RAD-95022) were completed by March 31, 1995. One RL milestone (RAD-95-019), "Complete all actions for Rev. 0 of the DOE Radiological Control Manual," was scheduled but not accomplished due to not completing the posting of RCAs within one area (Tank Waste Remediation Systems). There is no impact to the program baseline, no recovery plan, and the milestone is forecast for completion by April 7, 1995. All future milestone commitments are on schedule.

\subsubsection{Key Program Issues}

There were no issues identified in Radiological Control that meet the SMS definition for this reporting period. Radiological Problem Report information is discussed in Section 3.5 of this report.

\subsubsection{Health and Safety Statistics}

During the first quarter of 1995, the Radiological Control organization experienced six OSHA recordable injury/illness incidents (with no lost time) and four incidents which resulted in restricted workdays. All four restrictions were due to strains/sprains of the shoulders and back. However, Radiological Control experienced no lost/restricted workday incidents for 56 days from January 19 to March 16, 1995. This surpasses a previous 1994 record. 


\subsection{EXTERNAL DOSIMETRY}

The protection of worker health and safety is of paramount concern within WHC. Since the Hanford Site is one of the largest nuclear sites in the nation, radiation safety is a key element in the protection program. The measurement of accumulated annual dose provides an indicator of the effectiveness of WHC radiation work practices and the ALARA Program with consideration given to fluctuating operating activities.

\subsubsection{Occupational Collective Dose}

Record dose reflected in this report is for period ending March 31, 1995. Numbers reflect data available from the Radiological Exposure (REX) system on April 26, 1995.

3.2.1.1 Cumulative Annual Occupational Collective Dose. The Figure 3-2-1 chart data includes WHC, BCSR, and ICF KH employee exposure. The results represent the exposure of 2,456 quarterly-badged employees and an average of 1,039 monthly-badged employees. The increased exposure shown in March is mainly attributed to higher dose-rate jobs and an increased amount of work performed by TWRS during the month.

Figure 3-2-1. Monthly, Quarterly \& Annual Exchange Dosimeter Results - CY 1995

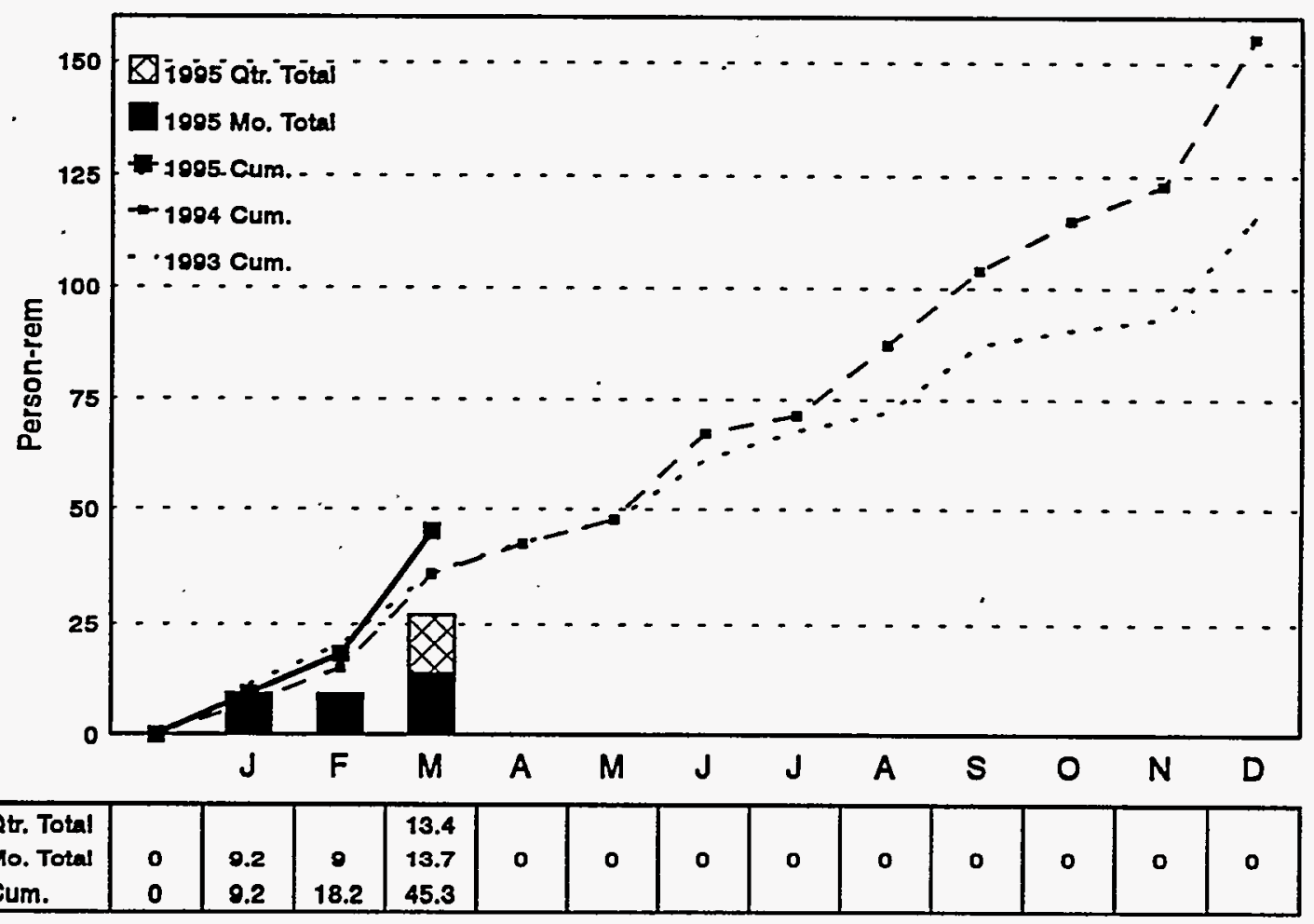

3.2.1.2 Individual Radiation Dose. Figure 3-2-2 depicts the cumulative average dose in mrem for monthly badged personnel for CY 1987 through CYTD 1995. 
Figure 3-2-2. Monthly Badged Employee Average Cumulative Radiation Dose

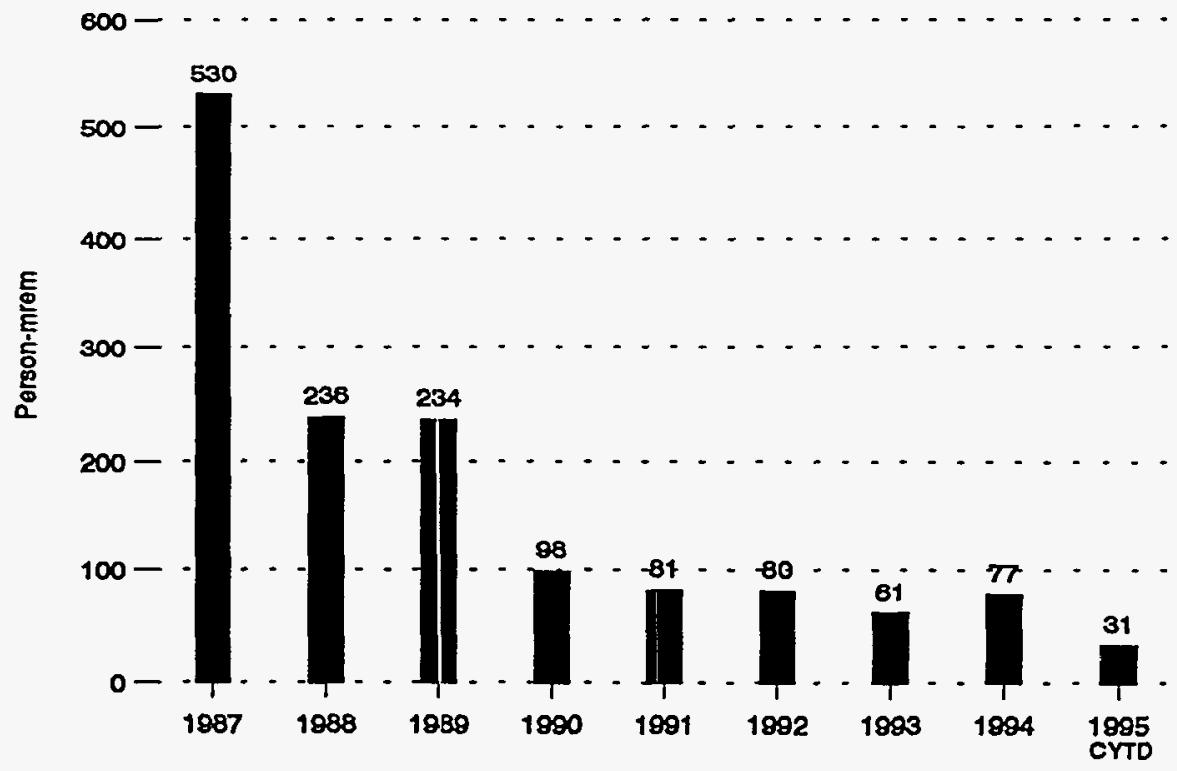

\subsubsection{High Whole Body Dose Evaluation}

Figure 3-2-3 illustrates whole body dose distribution, received onsite, among all WHC, BCSR, and ICF KH monthly frequency badged employees. Table 3-2-1 lists workers having the highest whole-body doses received onsite, during CY 1994, for monthly and quarterly frequency badged employees.

During the first quarter of CY 1995, there were no unplanned exposures, resulting in a dose greater than the administrative control level of $500 \mathrm{mrem} / \mathrm{year}$.

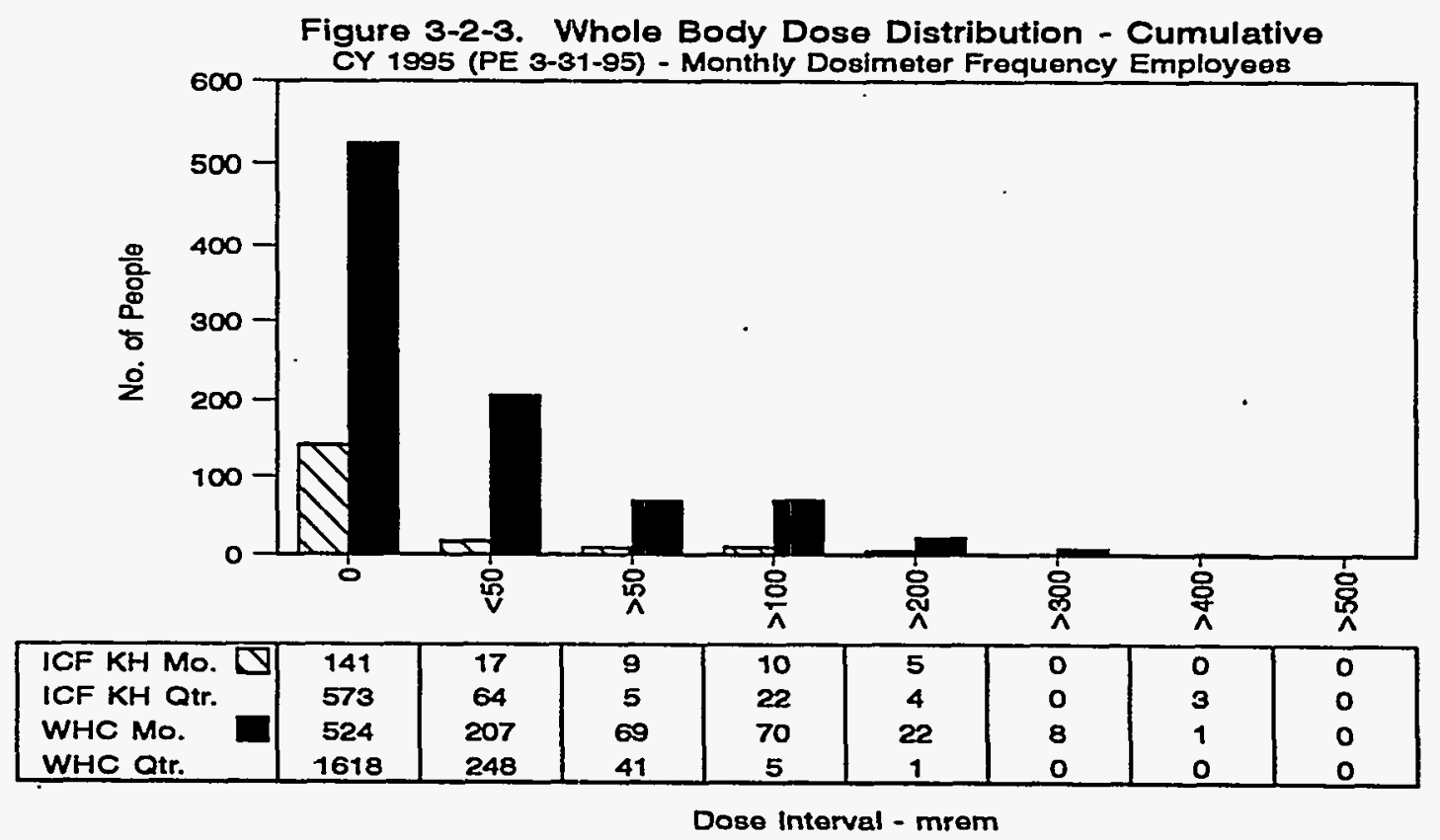


Table 3-2-1. Highest Whole Body Dose Employees

Includes external dose received by monthly and quarterly frequency badged employees.

\begin{tabular}{|l|c|c|l|c|c|}
\hline \multicolumn{1}{|c|}{ Craft } & $\begin{array}{c}\text { Whole Body } \\
\text { (mrem) }\end{array}$ & $\begin{array}{c}\text { Organization } \\
\text { Code }\end{array}$ & \multicolumn{1}{c|}{ Craft } & $\begin{array}{c}\text { Whole Body } \\
\text { (mrem) }\end{array}$ & $\begin{array}{c}\text { Organization } \\
\text { Code }\end{array}$ \\
\hline \hline Pipefitter & 438 & $5 \mathrm{~A} 308$ & Plant/Utility Operator & 316 & $7 \mathrm{C550}$ \\
\hline Pipefitter & 421 & $5 \mathrm{~A} 302$ & Plant/Utility Operator & 311 & 15350 \\
\hline Engineering Technician & 412 & 15370 & Plant/Utility Operator & 280 & $7 \mathrm{C610}$ \\
\hline Pipefitter & 401 & $5 \mathrm{~A} 308$ & Engineering Technician & 270 & 15370 \\
\hline Plant/Utility Operator & 393 & 15300 & Plant/Utility Operator & 264 & $2 \mathrm{A450}$ \\
\hline Misc. Service & 383 & 15300 & Plant/Utility Operator & 255 & $2 \mathrm{~A} 450$ \\
\hline Manager/Administrator & 351 & $7 \mathrm{C} 610$ & Plant/Utility Operator & 243 & $2 \mathrm{A440}$ \\
\hline Engineer & 336 & $7 \mathrm{CH} 50$ & Miscellaneous & 243 & 85401 \\
\hline Manager/Administrator & 326 & $2 \mathrm{A320}$ & Plant/Utility Operator & 241 & 7C610 \\
\hline Plant/Utility Operator & 320 & 15360 & Manager/Administrator & 240 & $15 \mathrm{D00}$ \\
\hline
\end{tabular}

\subsubsection{High Neutron Dose}

Figure 3-2-4 provides a 12-month rolling window of the highest neutron doses received onsite. The five highest neutron doses received during the first quarter of CY 1995 were recorded for employees at PFP.

Figure 3-2-4. Highest Neutron Dose

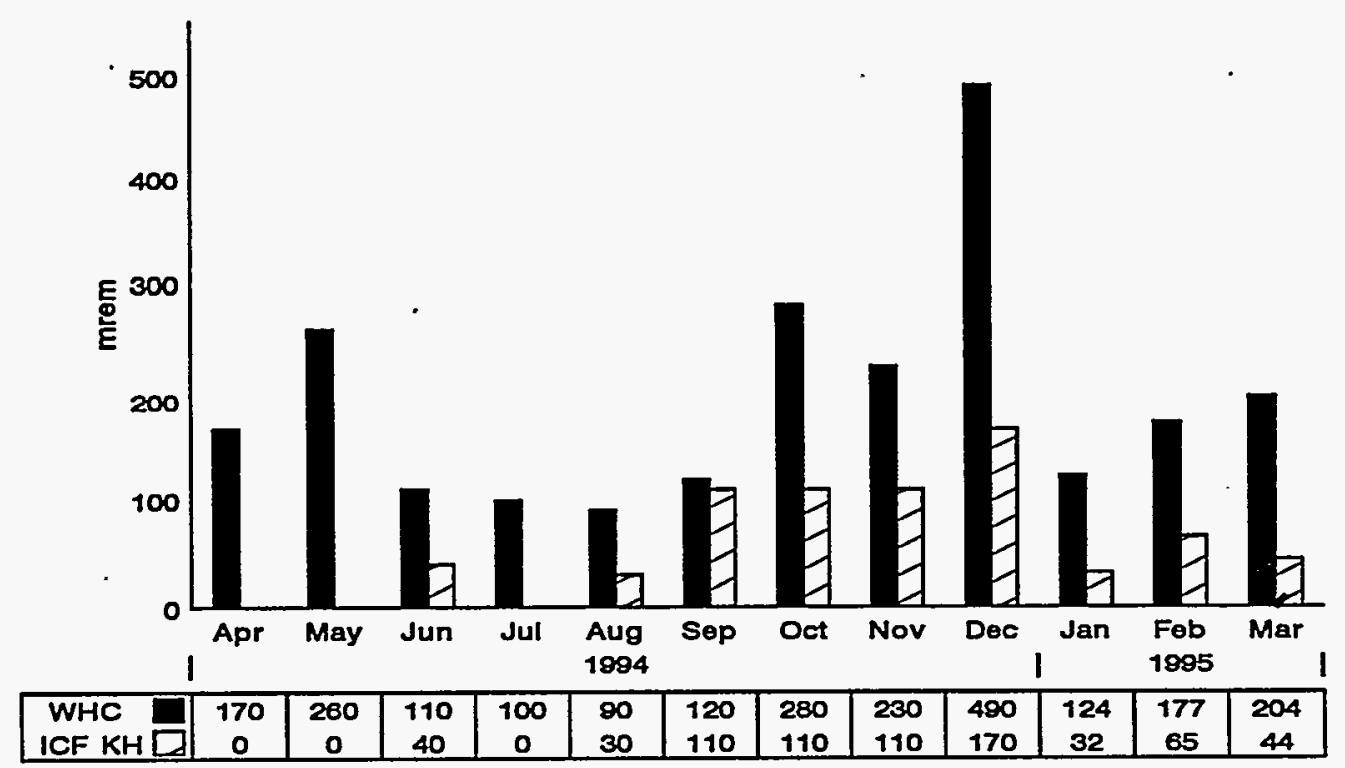

\subsection{INTERNAL DOSIMETRY}

Radiological Control is responsible for internal dosimetry emergency response following radiological events and for providing an internal dosimetry advisor to interface between: WHC, BCSR, and ICF KH workers, DOE, PNL Internal Dosimetry, WHC Dosimetry, HEHF, Radiological Control management and staff, and WHC Communications following events or positive routine bioassay examinations. 
WHC-SP-0564-37

\subsubsection{Internal Depositions}

Beginning in CY 1993, the DOE Radiological Control Manual required the dose from internal depositions be calculated as the 50-year committed effective dose equivalent (CEDE), and DOE Order 5000.3B established reporting criteria for internal depositions as $\geq 100 \mathrm{mrem}$ CEDE.

\subsubsection{Internal Dose Incident Follow-Up}

There were no confirmed intakes of radioactive material with assessed committed effective dose equivalent (CEDE) greater than or equal to 100 mrem during the first quarter of CY 1995 by either wound or inhalation.

There were four instances of potential loss of contamination control during the calendar quarter involving 11 workers where internal dosimetry follow-up was performed. No intakes of radioactive material were found and no internal dose was assessed for any of these cases.

- On 1/11/95 an employee working in the PUREX sample gallery received a superficial cut to the palm of the right hand on a blade used to open bagged, potentially contaminated gas cylinders. Field indications (blood smears and surveys of the blade) were negative. Wound counts were performed to rule out the possibility of an intake of mixed fission product contamination in the wound. No intake was confirmed.

- On 1/12/95 two workers at the 100-K East Fuel Storage Basin entered an area posted "Airborne Contamination" without appropriate respiratory protection. Follow-up whole body counts showed no indication of an intake.

- On 1/12/95 a worker was contaminated while working in the C Tank Farm of the 200 East Area. Mixed fission product contamination was found on the worker's hands, hair, and around the mouth. A follow-up whole body count showed no indication of an intake.

- On 1/31/95 there was a loss of contamination control in the 222-S Analytical Laboratory where workers were handling Tank Farm core extrusion samples in an open-faced hood. Seven workers were identified as having either positive nasal smears or nasal smears that may have showed positive indications due to radon interference. Whole body counts showed no indication of intakes for any of the workers.

\subsubsection{Update of Fourth Quarter CY 1994 Incident Follow-up}

On 12/13/94 there was a loss of contamination control at the Plutonium Finishing Plant where workers were handling a container of scrap material as part of the plutonium sludge stabilization work. A room continuous air monitor (CAM) alarmed and workers immediately left the work area. Follow up bioassays showed indications of uptakes for two workers. Final dose estimates issued in February 1995 showed one worker with a CEDE of 210 mrem and a second worker with a CEDE of 19 mrem. These doses are assigned to the year of intake, 1994. One of the inhalation intakes is above the DOE 5000.3B reporting criteria. The summary for CY 1994 of intakes of radioactive material with CEDE greater than or equal to 100 mrem should now read as follows:

\begin{tabular}{|c|c|c|c|}
\hline First Quarter & Second Quarter & Third Quarter & Fourth Quarter \\
\hline $\begin{array}{c}\text { Inhalation - } 1 \\
\text { Wound - } 0\end{array}$ & $\begin{array}{c}\text { Inhalation - } 0 \\
\text { Wound - } 0\end{array}$ & $\begin{array}{c}\text { Inhalation - } 0 \\
\text { Wound - } 0\end{array}$ & $\begin{array}{l}\text { Inhalation - } 1 \\
\text { Wound - } 0 \text {. }\end{array}$ \\
\hline
\end{tabular}




\subsubsection{Direct (in vivo) and Indirect (in vitro) Measurement}

The statistics for total number of urine samples is based on the total number sampled. In vitro measurement statistics are presented in Figure 3-3-1 for CY 1995. Statistics are also included for invalid samples:

- No sample - Workers did not provide a sample for a delivered container

- Lost containers - Workers did not return the containers to the analytical laboratory, or as in the first quarter, the containers were deficient

- Insufficient volumes - Workers did not provide an acceptable amount of urine for analysis

- Lost in laboratory - The analytical laboratory lost the worker's sample during the processing.

Figure 3-3-1. Indirect (In Vitro) Measurements

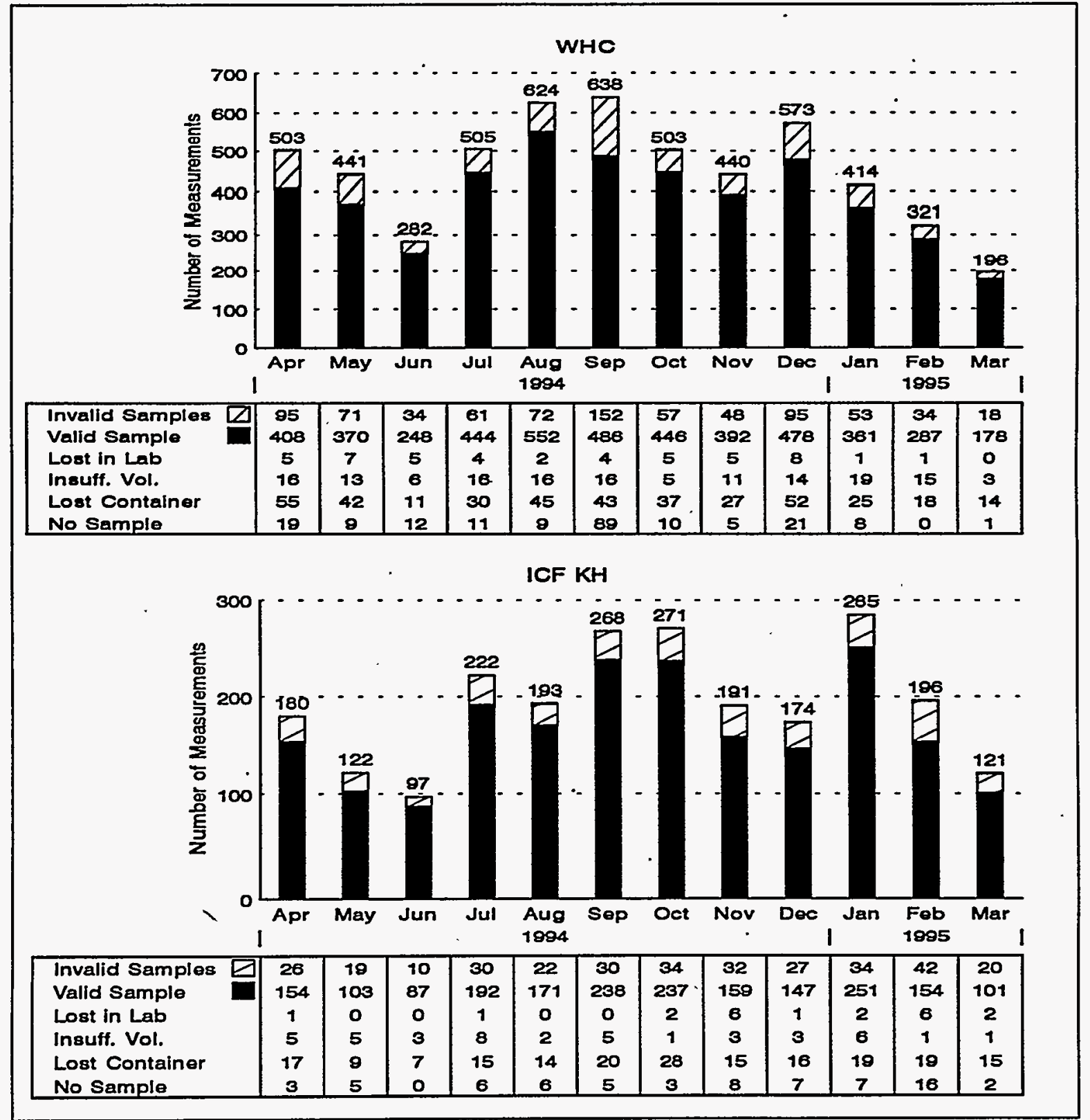


In vivo measurements are accumulated by measurement type: Whole. body, chest (lung), and head. All other types of measurements performed (e.g., wound, thyroid) are contained in the "Other" category. The "no-show" category contains the number of chest measurements in which scheduled workers did not report to the PNL In Vivo Radioassay and Research Facility (Figure 3-3-2).

Figure 3-3-2. Direct (In Vivo) Measurements

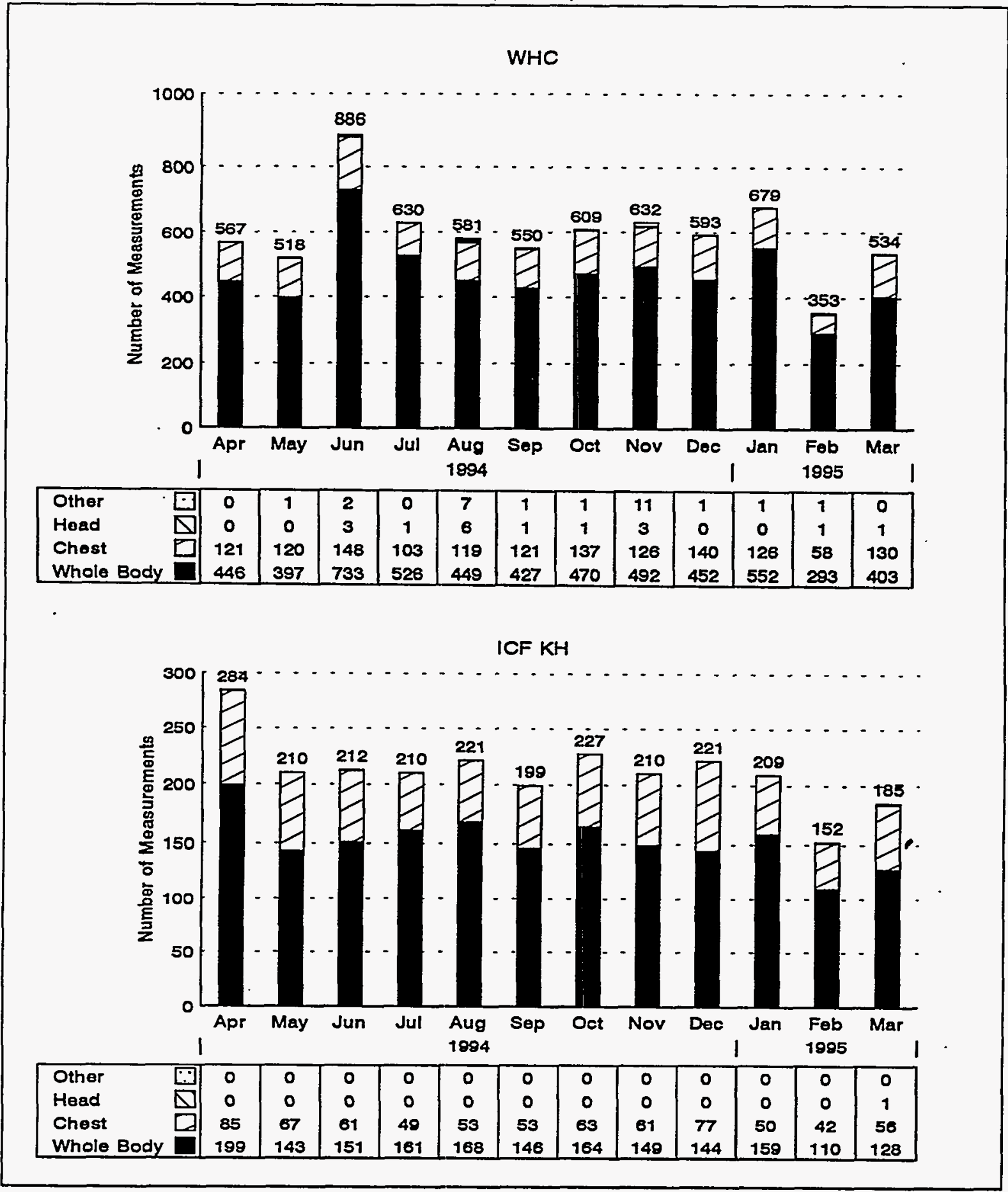




\subsection{SKIN AND CLOTHING CONTAMINATIONS}

Skin contaminations are of little consequence to employee health and safety, unless they result in significant radiation dose or internal depositions. Each skin contamination incident, however, does represent the potential for a more serious occurrence.

\subsubsection{Cumulative CY 1995 Skin Contaminations and Clothing Contaminations}

There were eight skin contaminations reported during the first calendar quarter WHC-managed facilities/operations. The skin contaminations occurred at PFP (2), Analytical Laboratories (2), Tank Farms (1), PUREX (1), T Plant (1), and K Basins (1). These events resulted "very low level exposures with no readings exceeding $10,000 \mathrm{dpm}$ beta/gamma or $700 \mathrm{dpm}$ alpha contamination.

Twenty clothing contaminations were reported during this same period: Tank Farms (11), $\mathrm{K}$ Basins (2), PUREX (2), Analytical Laboratories (3), and PFP (2). These events resulted in contaminations identified as "low" level contaminations: $\geq 20,000$ but $<100,000 \mathrm{dpm}$ beta/gamma or $\geq 1,000 \mathrm{dpm}$ but $<40,000 \mathrm{dpm}$ alpha.

Figure 3-4-1. 1995 Skin and Clothing Contaminations

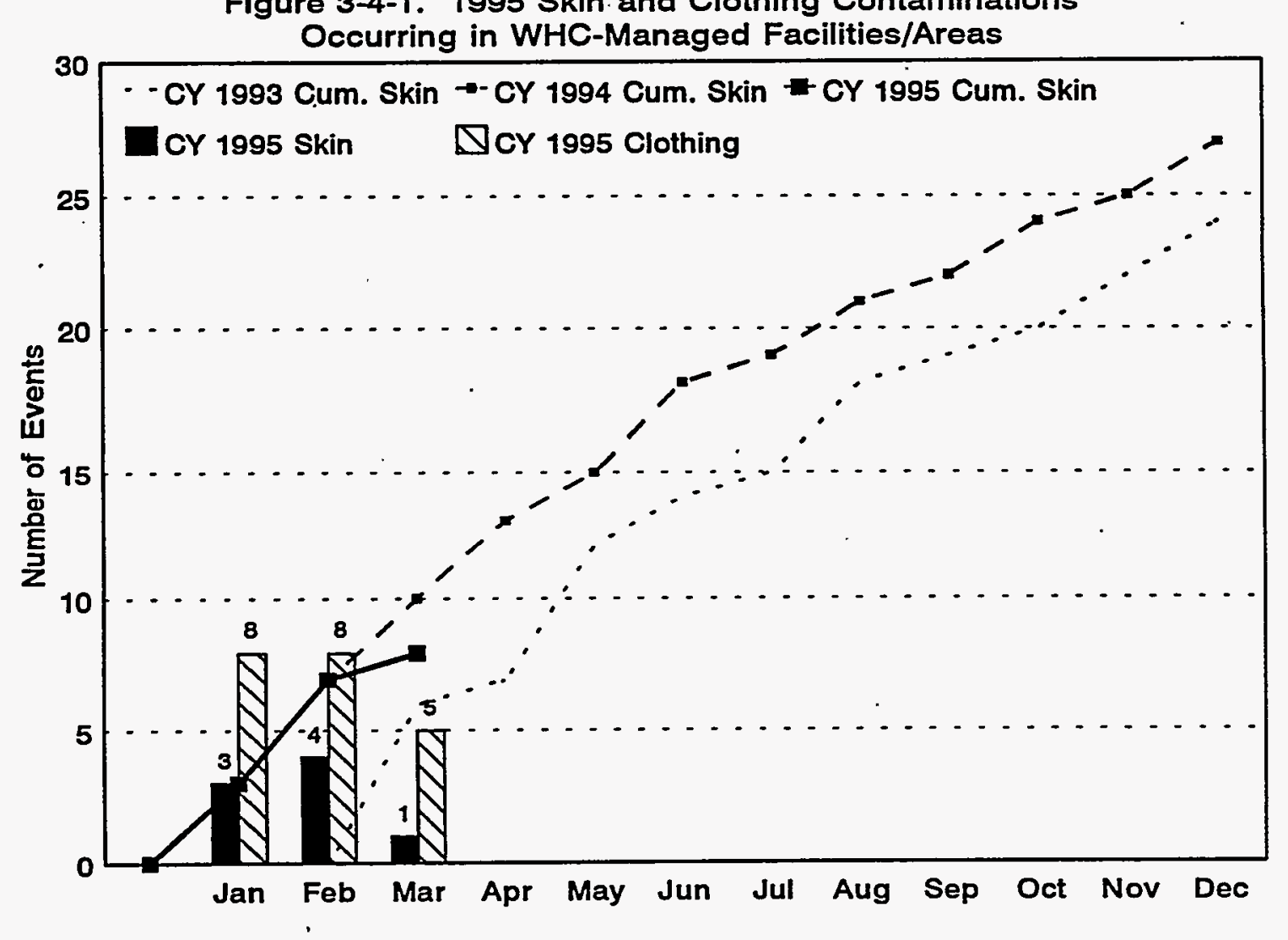


3.4.2 Significant Skin Contaminations. Significant skin contaminations are defined as a skin contamination resulting in a skin dose greater than or equal to one percent of the DOE dose limit, and are an indicator of the effectiveness of WHC radiation work practices and the efficiency of protective equipment. There have been no significant skin contaminations reported in WHC-managed facilities or areas since the one reported during CY 1988.

\subsubsection{Facial Contaminations}

Facial contaminations hold the potential for inhalation of radioactive material resulting in an internal deposition. The probable causes of the facial contamination incidents during this quarter is given below. Figure 3-4-2 depicts the number of facial contaminations for the last 12 months.

- On 1/12/95, while conducting routine radiological surveys in C-Farm, an HPT received contamination to numerous areas on the face and hand. After extensive investigation, no source of the contamination could be found and the final report was submitted without cause or corrective actions.

- On 3/2/95, following work in $\mathrm{K}$ Basins, a contract employee received contamination to the left cheek from contact with contaminated water. The probable cause was protective clothing (face shield) not worn as prescribed.

Figure 3-4-2. Facial Contaminations

Received in WHC-Managed Facilities/Areas

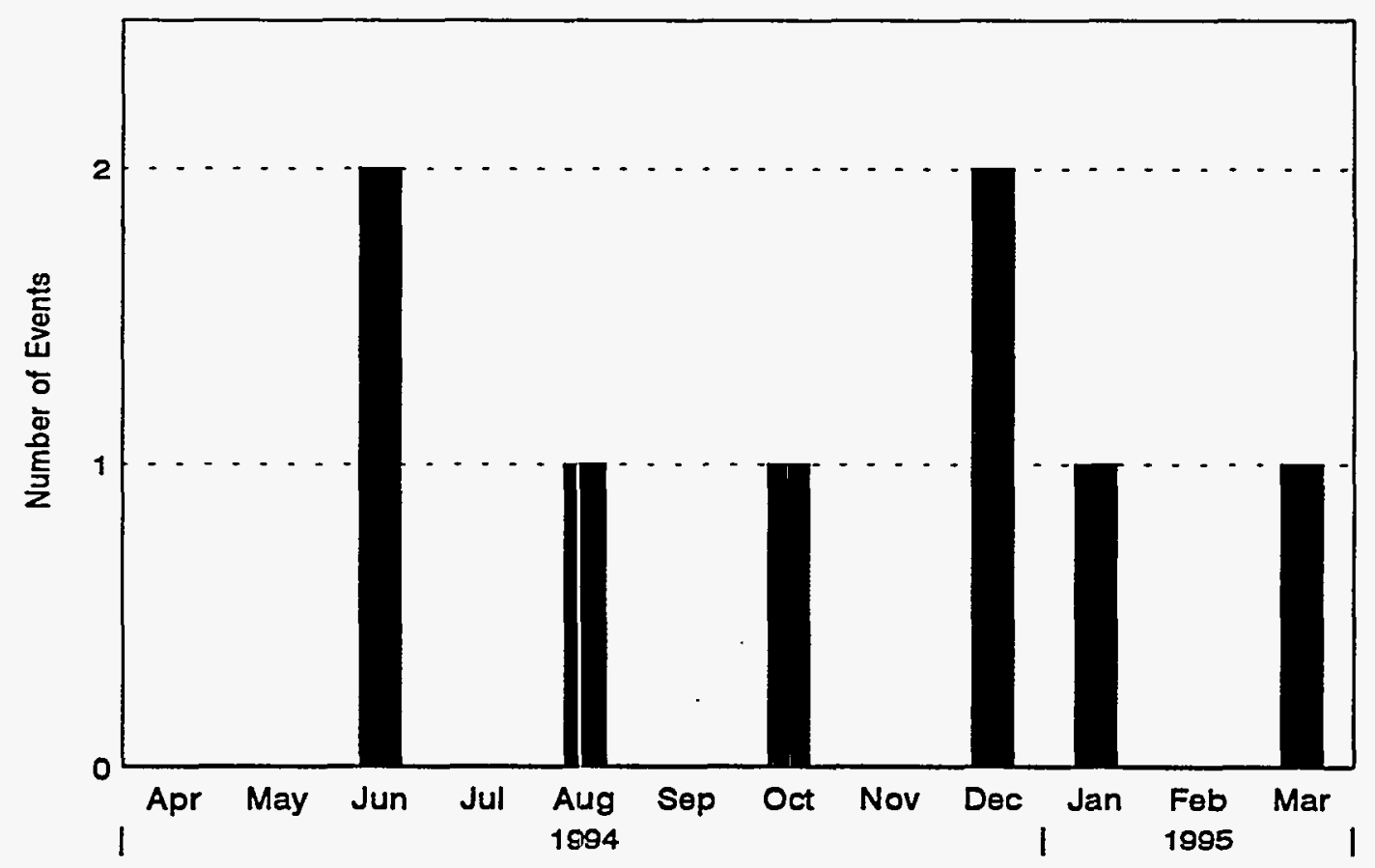




\subsubsection{Skin and Clothing Contamination Report Review}

The ALARA/CCIP Program Office with the assistance of Safety Awareness and Performance, and Dosimetry performed an analysis of skin and clothing contaminations occurring during FY 1995 in WHC-managed facilities/areas. All of the WHC skin and clothing contamination incident-reports and the latest Occurrence Reporting and Processing System reports were reviewed in an effort to identify possible trends.

In most cases it appears that a thorough and complete investigation has been completed and documented on the reports. However, review of the clothing contamination reports indicated the root cause of $29 \%$ of the cases was listed as "Unknown." The analyses revealed, in many of these cases, several distinct contributing factors could have been considered as the root or probable cause.

The analyses of the skin contamination reports indicates a more definitive classification of the root causes (Figure 3-4-3). Due to the increased emphasis being placed on the reduction of skin and clothing contaminations, a regular quarterly analysis will be performed and the results reported here.

Figure 3-4-3. Personnel Contaminations by Cause for FYTD 1995 - 10/1/94 through 3/31/95

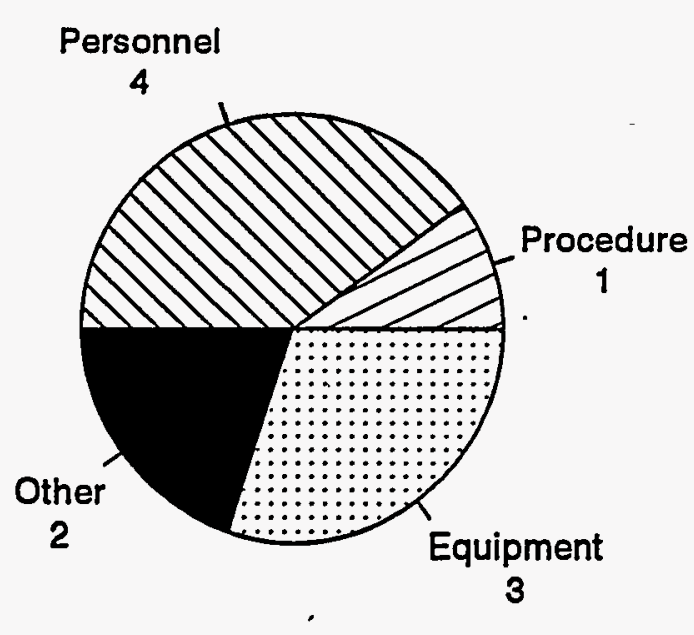

Skin Contaminations

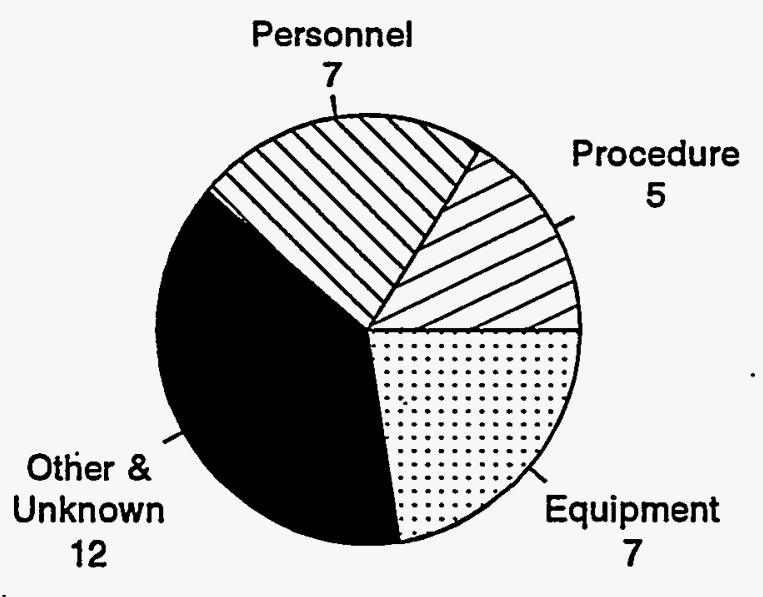

Clothing Contaminations 


\subsection{RADIOLOGICAL PROBLEM REPORTS}

A Radiological Problem Report (RPR) is issued to responsible managers as a method to communicate problems needing correction, monitoring or tracking. Tracking the number of issued reports can provide an indication of both the number of problems needing attention and the adequacy of documentation of these problems by Radiological Control. Tracking the number of open reports provides an indication of the responsiveness of line management in resolving problems of a radiological nature. Tracking the length of time needed to close an RPR is an indicator of the cooperative efforts expended by Radiological Control personnel and the line management with whom they deal in resolving these problems.

The deficiencies noted on RPRs are coded by type, cause, and severity. This information allows extraction of the data for analysis of the types of deficiencies that are occurring, the causes of those deficiencies, and the length of time necessary to accomplish resolution.

\subsubsection{RPRs Issued}

A monthly average of 106 RPRs was issued during the first quarter of CY 1994 for a total issuance of 320 RPRs. The monthly average for the same quarter in CY 1995 was 72; a total of 218 for the quarter (Figure 3-5-1).

The total number of RPRs written during the first quarter of 1995 was 218, 32 percent fewer than the number written during the first quarter of 1994 and 1993 . One reason for this decrease continues to be an increasingly cooperative effort between Radiological Control and the actionees to avoid radiological problems through a proactive approach (ALARA). Also, a more concerted effort has been placed upon the prescreening of initial RPRs by the issuing management teams in order to ensure the accuracy and validity of the RPR process.

Figure 3-5-1. Cumulative RPR Reports Issued

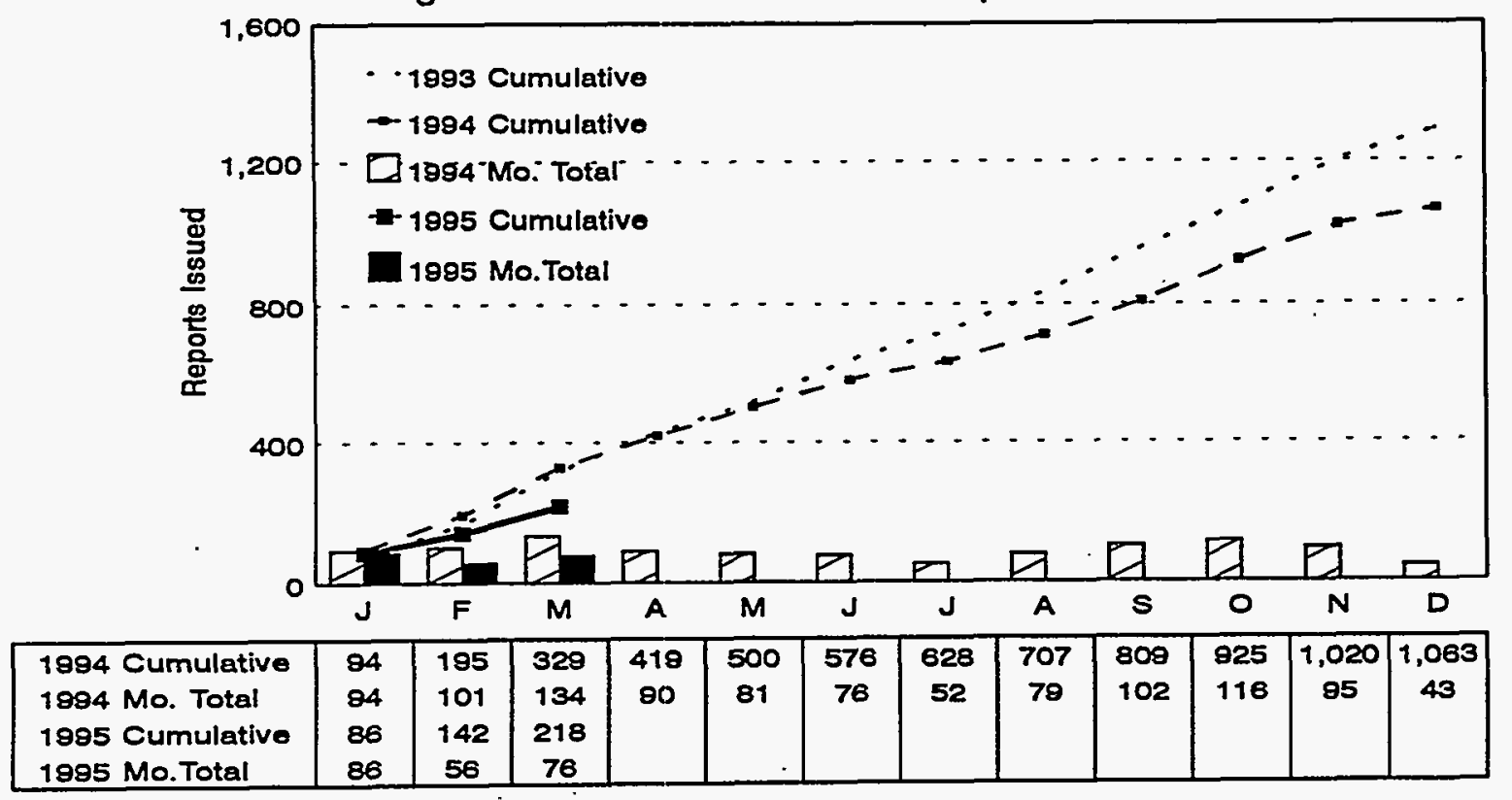




\subsubsection{Factors Influencing the Number of RPRs Written}

- The general decrease in numbers of RPRs written from 1994 to 1995 reflects the continued downsizing of production in WHC-managed facilities in addition to an increased awareness of radiological issues. Refer to Figure 3-5-2.

- The increase in awareness of ALARA principles and their application accounts in part for the decrease in radiological deficiencies. Cooperative efforts between Radiological Control and its customers have brought more attention to ALARA as a continual approach to hazard management and safe job performance. The ALARA personnel in work areas and the ALARA involvement with the planning of radiological work has also improved performance.

Figure 3-5-2. Facilities Issued RPRs - First Quarter Comparison

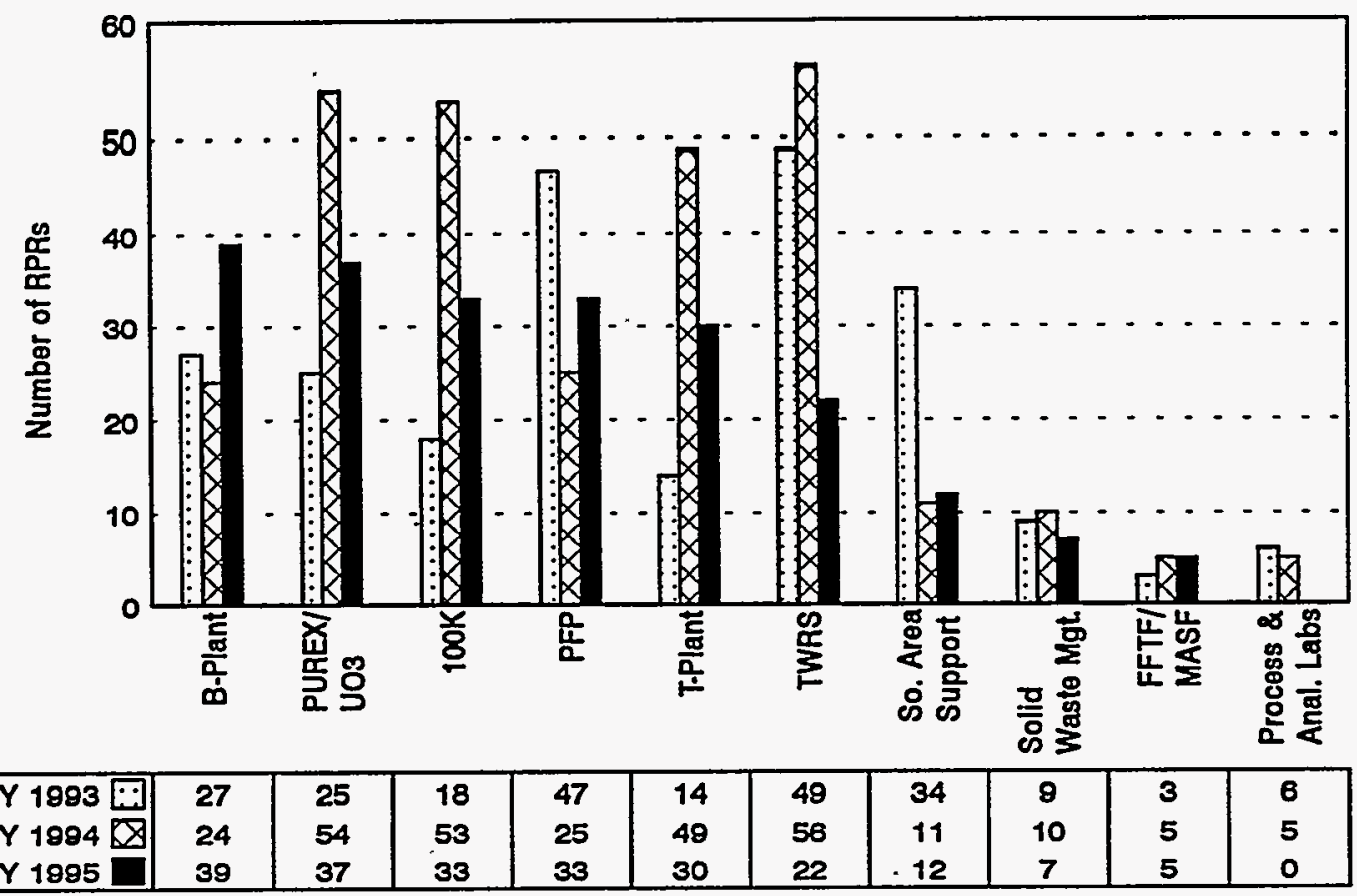

\subsubsection{RPR Trends}

The deficiencies noted by the RPR system are coded by type, cause, and severity. This information allows extraction of the data for analysis of the types of deficiencies that are occurring, the cause and severity of those deficiencies, and the length of time necessary for resolution.

3.5.2.1 RPRs by Priority Planning Grid (PPG). The Hanford Site uses the DOE required PPG system to grade radiological and safety deficiencies.

The actionee is responsible for determining the priority and weight of each deficiency requiring formal corrective action. Once this has been determined, assigned values make the evaluation of the urgency of completion more readily understandable and comparable with other corrective action measures. For further information, refer to WHC-CM-1-4, Corrective Action Management Manual. 
During the first quarter of 1995, of all PPG-graded RPRs, 79\% have been weighted at under 6 , about $19 \%$ were weighted at $\geq 6$ and $<11$, and $2 \%$ were weighted at $\geq 11$ and $<25$.

Of the RPRs that have not been assigned PPG values, most were issued for information only or were closed within 30 days, as a continuing cooperative effort on the part of Radiological Control and its' customers, to maintain the site ALARA. Many of these RPRs, issued for information purposes, are record issues already being tracked by the facilities as occurrence reports, and therefore RPRs were not evaluated for PPG with the responsible tracking being done via the occurrence report system.

3.5.2.2 RPRs by Type and Cause. A total of 218 RPRs had been written on radiological deficiencies during the first quarter of 1995, and of those written, 158 were reported for various radiation contamination situations (EV - Event), which is $72 \%$ of the total written. Of those issued for Events, 38 (24\%) were listed as unknown causes (the absence of directly discernable evidence) for the source of the radiological contamination. Emphasis has been stressed in an attempt to improve the discernment of causes for an event in order to improve trending analysis. Of all RPRs issued, equipment and material-related causes were cited as the leading statistical attributes for this first quarter's cycle.

Of all RPRs written, material and equipment, "Equipment," has replaced "Other" as the primary cause; a total of 75 or $34 \%$. Personnel issues with $65(30 \%)$ is second. It is easier to work with the equipment and personnel issues since they are very specific and can be detailed. Within the framework of the "Other" categories, those issues with unknown causes are being trended by area/location and watched for recurrence. Natural phenomena can only be controlled to a certain extent - tumbleweeds gathered and/or mulched, areas blocked from animal intrusion. Those unknown causes, as they recur, need to be revisited and trended closely. The Radiological Control organization monitors causal factors by more appropriately designating causes to deficiencies as much as is discernable. The trend toward an increase of equipment and personnel identified causes is a reflection of the increased awareness of personal accountability in the workplace.

Of the RPRs listed with PPGs greater than or equal to 6 and less than 11, the majority are type coded as Event (72\%) and then Administrative (28\%). The two leading causes in this area are listed as Equipment/material (44\%) with Procedure related deficiencies listed as a cause for $39 \%$ of the issues within this PPG range. There were no items listed in the Other Unknown) category for this PPG range.

The RPRs listed with a PPG of greater than or equal to 11 (3 each) list Administrative as the primary type (66\%) and Procedure problem as the primary cause $(66 \%)$. Inadequate administrative control accounts for the balance. The highest rated RPR (PPG 11) dealt the activation of a radiation generating device without the proper administrative controls in place.

Radiological Problem Reports are written to document radiological problems. The majority of them therefore list "radiological events" as primary types. Causal factors do need to be identified and investigated, especially those that recur. Personnel errors, administrative issues, procedural and 
training issues are observed and monitored, and the correlation of causal factors must be done at each field office, recurrences taken into account, and trends established. Taken together, equipment and personnel issues account for the majority of all coded RPRs for this quarter. Radiological Control and the actionees have shown improvement in specifying causes and attempting to resolve them at low-level status. This effort is indicated by the less frequent assignment of "other - unknown" as a cause and the general decrease in RPRs currently being issued (Figure 3-5-3).

Figure 3-5-3. RPRs by Type/Cause

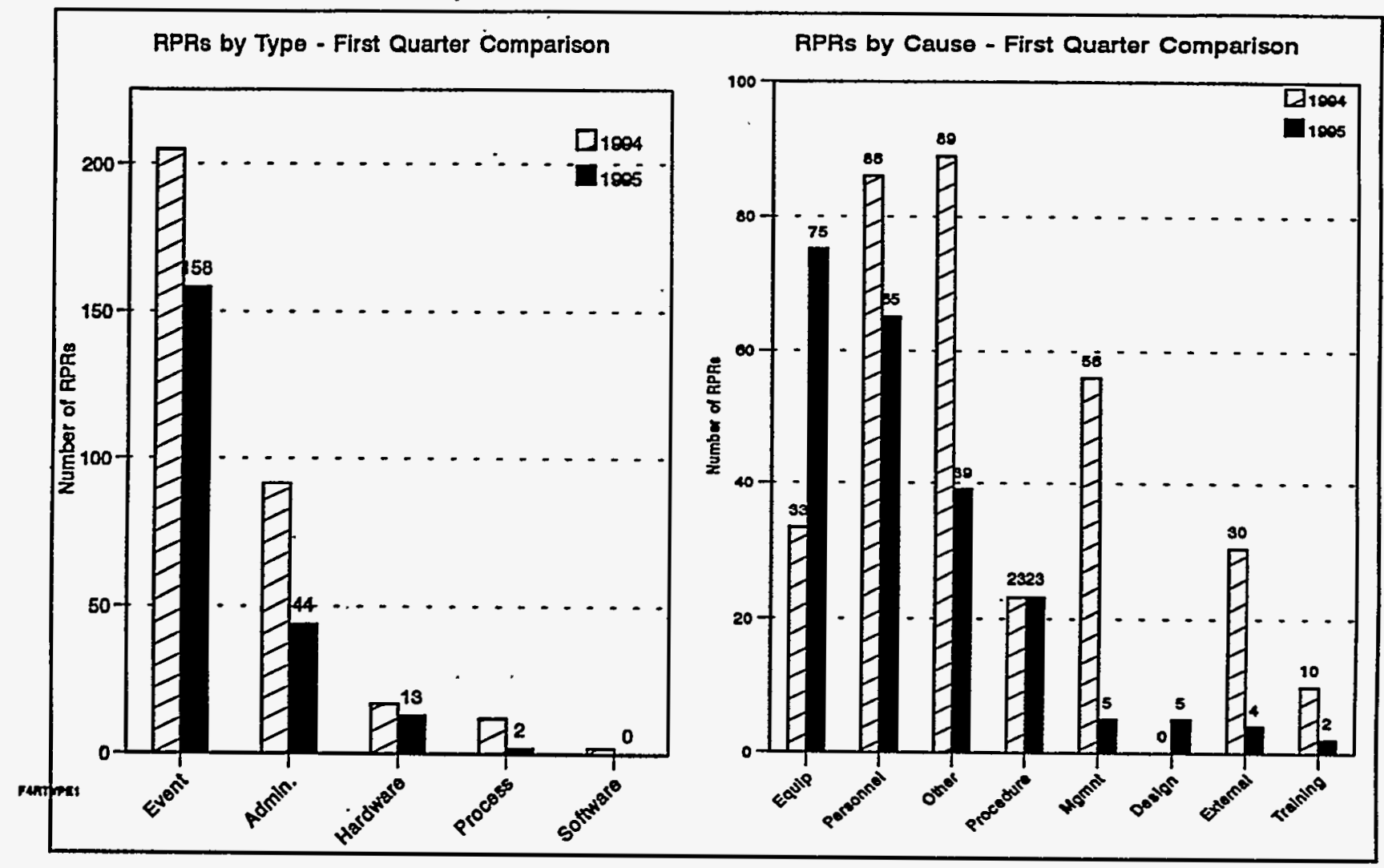

3.5.2.3 Contamination Events. The total number of contamination events reported for first quarter decreased from the previous 1994 first quarter cycle of (183 to 158 - about 14\%). The shift in facility related incidents is consistent with the reported activities in the various facilities (Figure 3-55). The primary causes listed for all events include Equipment, Material and Hardware (34\%), Personnel Errors (30\%) as the leading issues. The Other, undetermined direct and root cause factors, accounted for eighteen percent - the third leading variable. Of the Other category, equipment and facility related contamination represented seventy-two percent of the type category and as such, relates to specific quantifiable detail and is considered controllable as monitored occurrence anomalies. Procedure accounted for about 11\%. Design, External, and Training related causal types individually listed less than two percent as a causal factor during this evaluation of all contamination event cases listed.

Of the designated categories, where personnel issues account for $30 \%$ of the events listed for the first quarter performance cycle, personnel issues, equipment, material, hardware and processes are situations that can be identified and controlled. All of these items validate the recent emphasis on the part of WHC Management's attention to an improvement in the Conduct of Operations and selfassessment as a method toward achieving improved radiological protection. 
WHC-SP-0564-37

\subsubsection{Average Time to Close an RPR}

The number of RPRs closed during the first quarter of 1995 was 231 , compared to the 302 closed during the fourth quarter cycle of 1994; a variance of about $-24 \%$ in closure activity. On the surface, this might appear as a slow down in activity. However, when compared with the past performance of 1994 RPR issue rates (-30\% decrease) and the general trend occurring with recent company down-size in operations, the condition is consistent with expected performance activity and is not as, yet, a significant trend. More than half of all RPRs are closed during the 0 to 30-day time frame (60\% in 1994 and $63 \%$ in 1995 first quarter) with the balance following closure through two years. Most RPRs are closed within the first six months (86\% in 1994 and $91 \%$ in the 1995 first quarter). Those that have been open longer than a year are monitored and extensions have been requested in order to complete them adequately. Efforts remain underway to resolve these issues and allow closure of the RPRs.

3.5.3.1 Open RPRs. There were 186 RPRs open at the end of March 1995; a decrease of about $7 \%$ from January 1995 . About $49 \%$ of open RPRs have been open longer than six months. The issues for dealing with older RPRs is consistent with the priority of the costs necessary to remediate recurring legacy type anomalies within aging facilities. Long-opened RPRs remain open due to cost factors involyed with their remediation. In many instances, there are no immediate corrective actions. They predominantly remain open for tracking purposes.

Until recently, TWRS consistently wrote the highest number of RPRs and continues to show the largest number of open RPRs (89) in the system. However recent implementation of radiological assessment and a more objective criteria for RPR issuance within the TWRS areas have resulted in a change. For TWRS a significant decrease in RPR issuance has been experienced (-60\%). An effort to monitor the variance will continue.

The RPRs continue to have a low priority on corrective action management, which seems to account for most of the delays in resolution.

3.5.3.2 RPR Average Days Open. Radiological Control continues to work with the actionees to close out the older RPRs. Extended completion dates and cost impacted priorities account for the extended ages of certain RPRs within the system. The TWRS organization has the largest number of open (89) and delinquent RPRs. Of the delinquent RPRs that have been prioritized, the average range is below 6 on the priority grid.

\subsection{DOSIMETRY}

The WHC Dosimetry organization administers the dosimetry system that measures and records various types of external and internal radiation exposures occurring in WHC-managed facilities. All record and supplemental dosimeters for WHC, BCSR, ICF KH, and DOE, all of their visitors, subcontractors, vendors and tour participants are issued and processed by the Dosimetry Group. These dosimeter data are recorded and reported as required.

The Dosimetry organization is responsible for tracking and monitoring declared pregnant workers, conducting monthly dosimeter audits and status reports, and in vivo and in vitro scheduling and reporting. To ensure exposures are kept ALARA, the Dosimetry Group performs daily exposure checks and audits, provides the ALARA Program Office with daily input on exposures, and provides an ongoing history for tracking employees from date of hire to date of termination. 
The Dosimetry organization offices were moved from the 200 East Area to MO-287 in 200 West Area during March. All regular Dosimetry operations and special work was completed on time.

At the end of March, Dosimetry was monitoring 11 pregnant workers on a monthly exchange and one pregnant worker on a weekly exchange. There was no dose received by a pregnant worker during the first quarter.

Work restrictions were issued for nonreturn of 224 dosimeters and 46 finger rings.

Estimates and investigations of dosimeter results are performed when Dosimetry is notified of a lost or damaged dosimeter. The results of these investigations are sent to PNL to be included in the employee's record radiation exposure file. The first quarter totals are illustrated in figure 3-6-1.

Figure 3-6-1. Dose Assessments Performed for Lost or Damaged Dosimeters (Does not include assessments performed to close work restrictions issued for late dosimeter returns.)

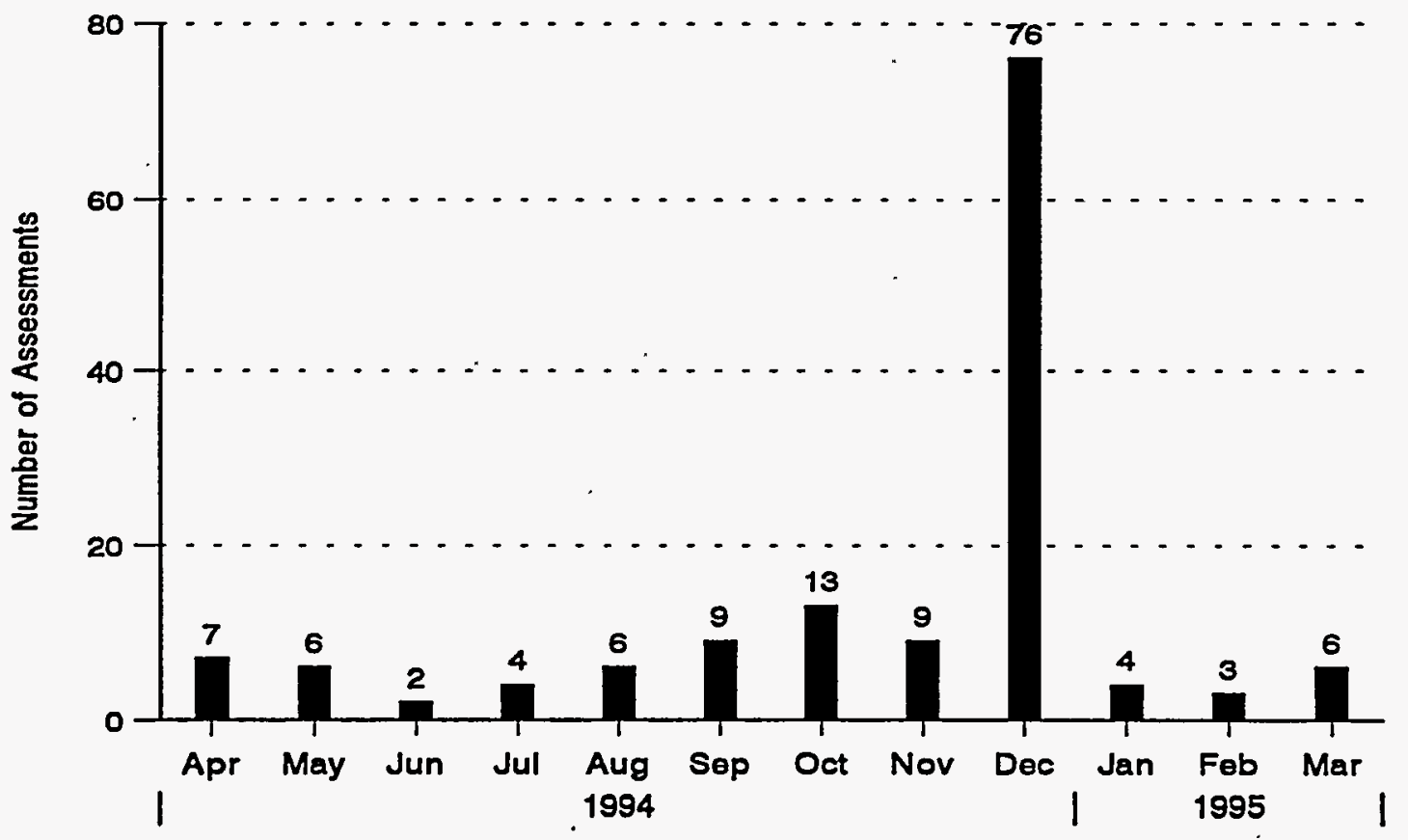




\section{REFERENCES}

BLS, Standard Industrial Classification Code Manual, SIC Code 4953, Bureau of Labor Statistics.

DOE, December 1994, Occupational Radiation Protection, Title 10, Code of Federal Regulations, Part 835 (10 CFR 835), U. S. Department of Energy.

DOL, September 1986, Recordkeeping Guidelines for Occupational Injuries and Illnesses, O.M.B. No. 1220-0029, U. S. Department of Labor, Bureau of Labor Statistics, The Occupational Safety and Health Act of 1970 and CFR 1904.

PNL/WHC/HEHF/BHI, December 9, 1994, HSRCM-1, Rev. 2, Hanford Site Radiological Control Manual, Richland, Washington.

WHC, 1988, ALARA Program Manual, WHC-CM-4-11, Westinghouse Hanford Company, Richland, Washington.

WHC, 1994, Corrective Action Management Manual, WHC-CM-1-4, Westinghouse Hanfore Company, Richland, Washington.

WHC, 1987, Industrial Safety Manual, WHC-CM-4-3, Westinghouse Hanford Company, Richland, Washington.

WHC, 1988, Job Control System Manual, WHC-CM-8-8, Westinghouse Hanford Company, Richland, Washington.

WHC, 1988, Management Requirements and Procedures, WHC-CM-1-3, Westinghouse Hanford Company, Richland, Washington. 
WHC-SP-0564-37

\section{CONTENTS}

A-1 CY 1994 and FY 1995 ALARA Sitewide Goals . . . . . . . . . . . . . A A-1

B-1 Injury/lliness Prevention Resources $\ldots \ldots \ldots \ldots \ldots \ldots \ldots \ldots \ldots \ldots$ B-1

B-2 WHC CY 1994 Recordable Vehicle Accidents - Second Quarter .......... B-5

Glossary Abbreviations, Acronyms, and Initialisms $\ldots \ldots \ldots \ldots \ldots \ldots \ldots$ GL-1

Definitions of Terms $\ldots \ldots \ldots \ldots \ldots \ldots \ldots \ldots \ldots \ldots \ldots \ldots \ldots \ldots \ldots \ldots$

Distribution . . . . . . . . . . . . . . . . . . . . . . . . . Distr-1 
WHC-SP-0564-37

This page intentionally left blank. 
Appendix 1. FY 1995 WHC ALARA Sitewide Goals

\begin{tabular}{|c|c|c|}
\hline No. & Goal & ECD \\
\hline 1. & $\begin{array}{l}\text { Administer a written system to alert line management of individuals approaching } \\
\text { exposure administrative control guidelines. Data output reports will be } \\
\text { disseminated so that adverse radiological trends can be readily identified and } \\
\text { corrected, as necessary. } \\
\text { Champion: APO/ALARA Committees } \\
\text { Analysis of Performance: A review of the current ALARA Tracking and } \\
\text { Management System (ATAMS), identified in Section 1.5, has been initiated with a } \\
\text { focus on improving and streamlining the process to ensure it is as "user friendly" } \\
\text { as possible. }\end{array}$ & $\begin{array}{c}09 / 30 / 95 \\
\text { Open }\end{array}$ \\
\hline 2. & $\begin{array}{l}\text { Develop a system by which materials for employee training and retraining } \\
\text { incorporate lessons learned from the corrective actions listed in the radiological } \\
\text { occurrence reports and Post ALARA Reviews. } \\
\text { Champion: APO/ALARA Council } \\
\text { Analysis of Performance: Don Gardner has been assigned as a training liaison } \\
\text { between Radiological Control and the Training organizations. Technical reviews of } \\
\text { ALARA/CCIP related training materials, by the ALARA/CCIP Program Office, assist } \\
\text { in ensuring that lessons learned and corrective actions are incorporated into } \\
\text { employee training and retraining. }\end{array}$ & $\begin{array}{l}\text { 12/31/94 } \\
\text { Complete }\end{array}$ \\
\hline 3. & $\begin{array}{l}\text { Develop and implement an employee "ALARA recognition program" to reward } \\
\text { workers that demonstrate an increased consciousness towards reducing their } \\
\text { exposure and the spread of radioactive contamination. } \\
\text { Champion: APO/ALARA Council . } \\
\text { Analysis of Performance: The WHC ALARA Recognition Program has completed a } \\
\text { new purpose statement which includes recognizing and rewarding employees and } \\
\text { teams that meet or exceed the established safety performance criteria. Due to } \\
\text { budgetting constraints the "ALARA Recognition Program" is not budgetted for FY } \\
\text { 1995. There is a limited number of ALARA awards remaining. }\end{array}$ & $\begin{array}{l}12 / 31 / 94 \\
\text { Complete }\end{array}$ \\
\hline 4. & $\begin{array}{l}\text { Further integrate ALARA Program/Radiological Engineering support and } \\
\text { methodology within facilities by continuing to provide information at both the } \\
\text { operational and field levels. } \\
\text { Champion: APO/Radiological Engineering } \\
\text { Analysis of Performance: The ALARA/CCIP Program Office Senior Health Physicist } \\
\text { has been activally involved increasing the field application of ALARA. As a result } \\
\text { of this addition, the field implementation and operational successes of ALARA are } \\
\text { on the increase. }\end{array}$ & $\begin{array}{l}09 / 30 / 95 \\
\text { Ongoing }\end{array}$ \\
\hline
\end{tabular}




\begin{tabular}{|c|c|c|}
\hline \multicolumn{3}{|c|}{ Appendix 1. FY 1995 WHC ALARA Sitewide Goals } \\
\hline No. & Goal & ECD \\
\hline 5. & $\begin{array}{l}\text { Each ALARA Committee shall identify or develop a system to review, evaluate, and } \\
\text { implement applicable ALARA suggestions. } \\
\text { Champion: APO/ALARA Committees } \\
\text { Analysis of Performance: The majority of the facilities have identified a method to } \\
\text { review, evaluate, and implement ALARA suggestions, as applicable. The methods } \\
\text { will be formally documented during the revisions to their controlling ALARA } \\
\text { manuals. }\end{array}$ & $\begin{array}{l}\text { 09/30/95 } \\
\text { Ongoing }\end{array}$ \\
\hline 6. & $\begin{array}{l}\text { Coordinate and sponsor an ALARA Workshop during FY } 1995 . \\
\text { Champion: APO/ALARA Council } \\
\text { Analysis of Performance: Due to budgetary constraints, the ALARA Workshop will } \\
\text { not be held as an exclusive training session. However, it will be conducted as a } \\
\text { part of the Hanford Health and Safety Exposition that is scheduled to be held in } \\
\text { April } 1995 .\end{array}$ & $\begin{array}{l}\text { O9/30/95 } \\
\text { Ongoing }\end{array}$ \\
\hline 7. & $\begin{array}{l}\text { The WHC ALARA Program will be reviewed to ensure compliance with Title 10, } \\
\text { Code of Federal Regulations, Part } 835, \text { "Occupational ALARA Program" } \\
\text { expectations. This shall include a review of the site programs technical content } \\
\text { and applicability. } \\
\text { Champion: APO } \\
\text { Analysis of Performance: Dr. Mel Carter conducted an independent review of the } \\
\text { WHC ALARA Program to ensure compliance with } \\
10 \text { CFR } 835 \text { requirements. }\end{array}$ & $\begin{array}{l}\text { 09/30/95 } \\
\text { Ongoing }\end{array}$ \\
\hline 8. & $\begin{array}{l}\text { Develop a training package that covers the changes in the WHC ALARA Program } \\
\text { resulting from the changes in the WHIC ALARA Program Manual. } \\
\text { Champion: APO } \\
\text { Analysis of Performance: Training has been revised by the ALARA/CCIP Program } \\
\text { Office to include the changes that will occur from the publication of the revise } \\
\text { WHC ALARA Program Manual. Course numbers have been applied for from } \\
\text { Hanford Training Center. }\end{array}$ & $\begin{array}{l}\text { 09/30/95 } \\
\text { Complete }\end{array}$ \\
\hline 9. & $\begin{array}{l}\text { Evaluate the necessity of developing a charter for the Hanford ALARA Forum. } \\
\text { Champion: APO } \\
\text { Analysis of Performance: Members of the Hanford Forum have been invited to join } \\
\text { the WHC ALARA Council. Currently, representatives from ICF KH and PNL are } \\
\text { attending. Bechtel, HEHF, and WPPSS have also been invited to participate. }\end{array}$ & $\begin{array}{l}03 / 31 / 95 \\
\text { Complete }\end{array}$ \\
\hline
\end{tabular}


Appendix 1. FY 1995 WHC ALARA Sitewide Goals

\begin{tabular}{|c|c|c|}
\hline No. & Goal & ECD \\
\hline 10. & $\begin{array}{l}\text { Develop and/or revise the facility/organizational specific ALARA implementing } \\
\text { procedure or plan (per the requirements of } \\
\text { WHC-IP-1043) for each WHC ALARA Committee. } \\
\text { Champion: APO/ALARA Committees } \\
\text { Analysis of Performance: The suggested format and contents have been } \\
\text { determined and an implementation plan will be designed after WHC-IP-1043 is } \\
\text { issued. }\end{array}$ & $\begin{array}{l}09 / 30 / 95 \\
\text { Ongoing }\end{array}$ \\
\hline 11. & $\begin{array}{l}\text { Maintain the number of skin contamination at } 0 \text { significant }<\text { or }=1 \% \text { of DOE } \\
\text { dose limit), and not more than } 29 \text { cumulative skin contaminations occurring during } \\
\text { FY } 1995 \text { at WHC-managed facilities/operations. } \\
\text { Champion: APO/ALARA Committees } \\
\text { Analysis of Performance: Through the second quarter of FY } 1995, \text { there were } 13 \\
\text { Cumulative skin contaminations. This goal was created using the total number of } \\
\text { detectable contaminations reported. }\end{array}$ & $\begin{array}{l}\text { 09/30/95 } \\
\text { Ongoing }\end{array}$ \\
\hline 12. & $\begin{array}{l}\text { Maintain the FY } 1995 \text { annual cumulative radiological exposure for radiation } \\
\text { workers (monitored with a Hanford standard dosimeter) at WHC-managed } \\
\text { facilities/operations at less than } 136 \text { person-rem. } \\
\text { Champion: APO/ALARA Committees } \\
\text { Analysis of Performance: A total of } 45 \text { person-rem was received during the second } \\
\text { quarter of FY } 1995 \text {. An evaluation is underway to determine if this goal need to } \\
\text { be revised due to the additional exposure from ICF KH workers. }\end{array}$ & $\begin{array}{l}\text { 09/30/95 } \\
\text { Ongoing }\end{array}$ \\
\hline 13. & $\begin{array}{l}\text { Maintain the number of personal effects clothing contaminations occurring at } \\
\text { WHC-managed facilities/operations for FY } 1995 \text { at } 73 \text { or less. } \\
\text { Champion: APO/ALARA Committees } \\
\text { Analysis of Performance: Through the second quarter of FY 1995, there were } 36 \\
\text { cumulative clothing contaminations. }\end{array}$ & $\begin{array}{l}09 / 30 / 95 \\
\text { Ongoing }\end{array}$ \\
\hline 14. & $\begin{array}{l}\text { Promote the reduction of radiological areas at WHC-managed facilities/operations } \\
\text { by a minimum of } 274,699.08 \text { sq. meters }(2,956,933 \text { sq. feet), in support of the } \\
\text { Contamination Control Improvement Project. } \\
\text { Champion: APO/ALARA Committees } \\
\text { Analysis of Performance: Through the second quarter of FY 1995, over } 3.6 \text { million } \\
\text { square feet of radiological area was reduced/downgraded. This goal was achieved } \\
\text { early in part due to the prioritization placed on this goal by the ALARA Committees. }\end{array}$ & $\begin{array}{l}\text { 09/30/95 } \\
\text { Complete }\end{array}$ \\
\hline
\end{tabular}


Appendix 1. FY 1995 WHC ALARA Sitewide Goals

\begin{tabular}{|l|l|l|}
\hline \hline No. & \multicolumn{1}{|c|}{ Goal } & ECD \\
\hline \hline 15. & $\begin{array}{l}\text { Perform a quarterly review and evaluation of exposure tracking reports and } \\
\text { skin/personnel contamination incidents, for potential trends. If trends are noted } \\
\text { that are correctable, utilize the DORITE process to correct these issues. } \\
\text { Champion: APO/ALARA Council }\end{array}$ & $\begin{array}{l}\text { O9/30/95 } \\
\text { Ongoing }\end{array}$ \\
& $\begin{array}{l}\text { Analysis of Performance: The second quarter review of the root causes of the } \\
\text { recorded skin/clothing contamination was conducted. The available statistics have } \\
\text { not indicated any trends that the DORITE process can address. }\end{array}$ & \\
\hline \hline
\end{tabular}


WHC-SP-0564-37

\section{Appendix B-1}

Resources

Listed below are a variety of resources available to assist in the injury/illness prevention effort.

WHC Field Safety Offices - Staff members are available to assist the line manager and accident investigators with occupational injury/illness investigations. The staff members will also assist with hazard evaluations, review of work practices, and safety meetings. To request assistance, contact one of the following field safety points-of-contact.

- Transition Projects Safety - 372-0399

- Site Safety Programs - 372-2991

- Tank Waste Remediation Systems Safety - 373-6976

- Spent Nuclear Fuel Safety - 373-3464

- Safety Operations Support - 372-2598

WHC Industrial Safety and Fire Protection (IS\&FP) - This organization can provide the following:

- Occupational Injury/lllness Investigations - Accident Investigators are available to assist with investigation and OSHA recordability determination. To request assistance, contact 376-9146, $376-2354$, or $376-9003$.

- Occupational Injury/llness Information - To receive more information on the following, contact

- $376-8872$ or $376-9141$.

- WHC/BCSR Occupational Injury/IIlness Report - A report that is provided weekly on Soft Reporting which is sorted by organization code or facility.

- Daily Report of WHC/BCSR Occupational Injuries/lllnesses via cc:mail.

- President's Accident Prevention Committee (PAPC) - Information that is provided to the PAPC.

- Safety Meeting Materials - Many resources are available through the Safety Resource Center to assist individuals with conducting their safety meetings effectively and to provide information on safety and health topics. Resources available include films, videos, literature, and assistance with individual safety programs. For information on these resources, contact the Safety Resource Center, 376-9059.

- Safety Awareness Programs - For information regarding company wide health and safety awareness programs that have been implemented for prevention of occupational injuries, illnesses and accidents, contact 376-9050.

ALARA - ALARA support is provided for goal development, training and awareness activities. For more information, contact 376-9035.

Ergonomic Disorder Testing - To arrange for ergonomic disorder testing by Hanford Environmental Health Foundation (HEHF) specialists, contact WHC Safety on 376-0194 or 372-3422. • 
Appendix B-1 (Continued)

Once a diagnosis has been made of the employee's physical problem and the specialist has evaluated the employee's worksite, the specialist will make recommendations. Approximately 4-6 weeks later, a reevaluation is made to determine if corrective actions are beneficial.

Fall Protection Program Training - This training is mandated for employees who work at elevated work location where the potential injury due to falls is present. This training covers regulatory requirements, proper use, testing and maintenance of hardware and safety equipment. This training meets OSHA and WHC requirements for fall protection training certification of at-risk employees and their managers/supervisors. For additional information, call 376-0687 or 376-0913.

Behavioral-Based Safety Training Course is a behavior based approach to safety. The course allows participants to identify barriers to safety, discuss the three elements of a Total Safety Culture, and learn how they can implement seven fundamental principles of the safety process. The course is currently being offered once each month. This training supports, and is a critical implementation and operation factor for, the Voluntary Protection Program (VPP).

- Currently to schedule training, send your request by cc:mail to the Training Registration mailbox. In the cc:mail message, include employee name, payroll \#, charge code, name of class, and course code number 020107. Also, if there is a date the employee is not available, include this information in order to avoid rescheduling of the class. Refer to Hanford Training Center (376-6736) if they have questions on how to use the cc:mailbox. Planned enhancements will allow direct scheduling of the employees via the HLAN and PeopleSoft.

- Additional support training for implementation of behavioral-based safety processes is available to Accident Preventions Councils, Safety Teams, or Safety Work Groups. To schedule a class, contact Health and Safety Training (372-3910).

Confined Space Entry Program Training - This course covers all life critical concerns for employees required to enter or work in confined spaces. The training covers the regulatory requirements, and proper use and testing of the appropriate safety harness and equipment required for confined space entry. This training is required for all entrants, attendants, and oversight personnel that are involved with a confined space entry. For more information contact $372-3110$ or 376-0913.

Safety Observer Training - This course is designed to assist in the training of employees in the recognition of the basic causes of accidents in the work place (unsafe acts and unsafe conditions). Program provides 8 to 10 hours of OSHA initial training, hazard recognition training, refresher Behavior Based Safety Training and various issue specific follow up training modules on request. For information, contact 372-3910, or 376-0913.

Occupational Safety and Health Program Training - This course is the four day presentation of the OSHA Code of Federal Regulations (CFR) 1910. The training provides an overview and understanding of the applicable Federal Regulations for the operations of the Hanford Site. The training instructs the student in the methods of using the CFR's as a resource, and recognition of hazards within the work place as identified by OSHA. For additional information call 37-4679 or 376-0913. 
Lock and Tag Program Training (initial and refresher) - This training is required for all employees that are classified as "authorized workers" within the site definition. This includes all employees that administer, verify, install or remove locks and tags in support of the established site procedure. The training addresses regulatory requirements, proper procedures and documentation requirements for the sitewide program. Additional information regarding the training and prerequisites can be obtained by calling $376-0830$ or $376-0913$.

Managers Safety Training - The course is designed to provide an initial four hour block of classroom training, followed with several one or two hour modules to be completed through-out the year as part of the managers Safety Improvement Plan. This allows the individual manager to schedule the training modules as needed or as available for optimum flexibility. Training must be completed to meet the SIP milestones. For additional information call 372-3200 or 376-0913.

Root Cause Analysis - Attendees of this course develop an understanding of several analysis methods for use in accident investigations. For information on this course, contact DOE-RL Quality Training and Resource Center (QTRC) on 376-7117.

Back Injury Prevention Programs - Back injury prevention programs (BackUp) are available by HEHF Occupational Health professionals for delivery at the Hanford worksite on a request basis to groups of 12 or more employees. Presentations generally vary from 30-60 minutes and are designed to promote employee health and safety. The mission of the programs are to provide the Hanford Site with an effective and cost efficient back pain/injury risk management program which results in a reduction of associated direct and indirect costs. To schedule a particular seminar, managers may cc:mail *HEHF Worksite Health, or call 376-0655.

- BackUp I - Education and Awareness for Reducing Back Injuries - This presentation will provide the essentials for understanding and managing back injuries in the workplace. BackUp is designed to increase employee awareness regarding anatomy of the back, proper body mechanics, back pain/injury common causes and self care.

- BackUp II - Body Mechanics - In this presentation, employees will take the next step toward back problems by learning how to improve their body mechanics at work and at home. Employees will also learn how to make their home and work environment safer and more productive by applying basic ergonomic principals (fitting the job to the person). Employees must attend BackUp I prior to scheduling this presentation.

- Adjusting Your Hardware, Maintaining Your Software - This ergonomics program teaches good posture and optimum comfort at the workstation. Making the proper adjustments at the VDT/computer terminal and learning stretching and relaxation exercises that relieve eye and muscle strain will reduce fatigue, stress, long term injuries and strains and increase comfort and productivity.

- BackUp Exercises for the Office Worker - This program is a continuing exercise program specifically intended to enhance back function. It is expected that improving the functional capabilities of body's muscles, ligaments and tendons will result in reduced frequency and/or . 
Appendix.B-1 (Continued)

severity of back related discomfort among employees. This program consists of one 60 minute hands-on presentation followed by two follow-up visits. There must be sufficient space for employees to stretch on mats on the ground in a $10^{\prime} \times 10^{\prime}$ space. Mangers must agree to allow their employees to stretch three times per week, 20 minutes per session.

- BackUp Exercises for the Material Handlers and Craftspersons - Many problems of the spine are related to the muscles and joints that support the back. An appropriate exercise program can help heal, rehabilitate and maintain the flexibility and strength of the musculoskeletal system. Employees will have the opportunity to establish a routine worksite stretching program that can be performed in business attire at the workstation. Employee will be required to attend BackUp I prior to participating in this presentation. Managers must agree to allow their employee to stretch three times per week, ten minutes per session.

Your Healthy Back - This is a four hour course that is offered by QTRC. This class also provides employees with information on what are the common reasons for back injury, and ways to prevent back injuries. A portion of this program is devoted to a stretching and strengthening session. For more information, contact 376-7117.

Supervising to Prevent Back Injuries - This is a five hour course that provides supervisors with information pertaining to the prevention of back injuries in the work place. For more information, contact QTRC (376-7117).

Wellness Seminars - Wellness seminars are available by HEHF Occupational Health professionals for delivery at the Hanford site on a request basis to groups of 12 or more employees. These presentations have been designed to promote employee health and safety, increase productivity and well-bẹing, as well as reduce absenteeism.

Below you will find the titles of the seminars offered by HEHF Health Promotions Services. To receive information or schedule a particular seminar, managers may cc:Mail HEHF Health Promotions mailbox, or call HEHF Health Promotion Services at 376-0655. Please schedule your presentations at least three weeks in advance.

- Adapting to Stress

- Body Fat Testing

- HIV \& Hepatitis B Awareness

- Laughter in the Workplace
- Low Fat Feasting

- Smoking Cessation

- Self Care - Cold \& Flue

- Stick-To-It Program

Below you will find the titles of the seminars offered by HEHF Behavioral Health Services. To receive information or schedule a particular seminar, call 376-1282.

- Achieving a Balanced Lifestyle

- Anger Management

- Be Your Best You

- Coping with Change
- I Have This Friend

- Just Relax

- Saving for Stress

- Talking to Yourself Can Drive You Sane 
Appendix B-2

CY 1995 First Quarter Recordable Government Vehicle Accidents

\begin{tabular}{|c|c|c|c|}
\hline Date & \$ Amount & Area & Description of Accident \\
\hline 01/05/95 & $\$ 1,032$. & $\begin{array}{l}2722 \mathrm{~W} \text { 21st St, } \\
200 \mathrm{~W} \text { Area }\end{array}$ & $\begin{array}{l}\text { Employee approached government truck from } \\
\text { behind, entered the truck and was backing } \\
\text { when it struck an unoccupied parked vehicle } \\
\text { with the tailgate lift. The parked vehicle } \\
\text { sustained damage to the right front door and } \\
\text { right front window. There were no injuries. }\end{array}$ \\
\hline $01 / 24 / 95$ & $\$ 7,420$. & $\begin{array}{l}3705 \text { Bldg. } \\
\text { Parking Lot, } \\
300 \text { Area }\end{array}$ & $\begin{array}{l}\text { Employee was backing government vehicle } \\
\text { from parking area to gain access to street. The } \\
\text { employee saw an orange cone on top of a } \\
\text { concrete light pole base, proceeded to back the } \\
\text { vehicle, misjudged the location of the light } \\
\text { base, and struck the light base puncturing the } \\
\text { vehicle's gas tank. There was approximately } 2 \\
\text { gallons of unleaded gas spilled. Vehicle } \\
\text { damage }-\$ 800 \text {. Gas spill clean/disposal costs } \\
-\$ 6,620 \text {. There were no injuries. }\end{array}$ \\
\hline 02/08/95 & $\begin{array}{l}\text { WHC vehicle } \\
-\$ 5,527 \text {. } \\
\text { (Other site } \\
\text { contractor } \\
\text { vehicle's } \\
\text { damage } \\
-\$ 6,665)\end{array}$ & $\begin{array}{c}\text { Rt 4S., MP 10.5, } \\
600 \text { Area }\end{array}$ & $\begin{array}{l}\text { An WHC employee was driving a government } \\
\text { vehicle slowly on the right shoulder of the road } \\
\text { while looking for the turn to an unfamiliar } \\
\text { work location. Upon spotting the turn on the } \\
\text { opposite side of the road, the employee pulled } \\
\text { the government vehicle back onto the roadway } \\
\text { in preparation to turn left. Moments after } \\
\text { signaling and beginning the turn, another } \\
\text { contractor government vehicle, which was } \\
\text { attempting to pass, collided broadside causing } \\
\text { extensive damage to both vehicles, as well as } \\
\text { injury to the two drivers and a passenger of the } \\
\text { second vehicle. }\end{array}$ \\
\hline 03/09/95 & $\$ 1,311$. & $\begin{array}{l}\text { Camden \& 23rd } \\
\text { St., 200W Area }\end{array}$ & $\begin{array}{l}\text { The employee was driving a government } \\
\text { vehicle North on. Camden, turning left onto } \\
\text { 23rd Street. As the vehicle was turning, a } \\
\text { clipboard placed on the dashboard of the } \\
\text { vehicle slid off distracting the employee } \\
\text { momentarily. The employee tried to reach for } \\
\text { the clipboard, overcorrecting the vehicle. The } \\
\text { driver's side mirror struck a power pole and } \\
\text { the bottom side of the vehicle struck a junction } \\
\text { box attached to the power pole. There were } \\
\text { no injuries. }\end{array}$ \\
\hline
\end{tabular}


WHC-SP-0564-37

This page is intentionally left blank.

B-6 


\section{GLOSSARY}

ABBREVIATIONS, ACRONYMS, AND INITIALISMS

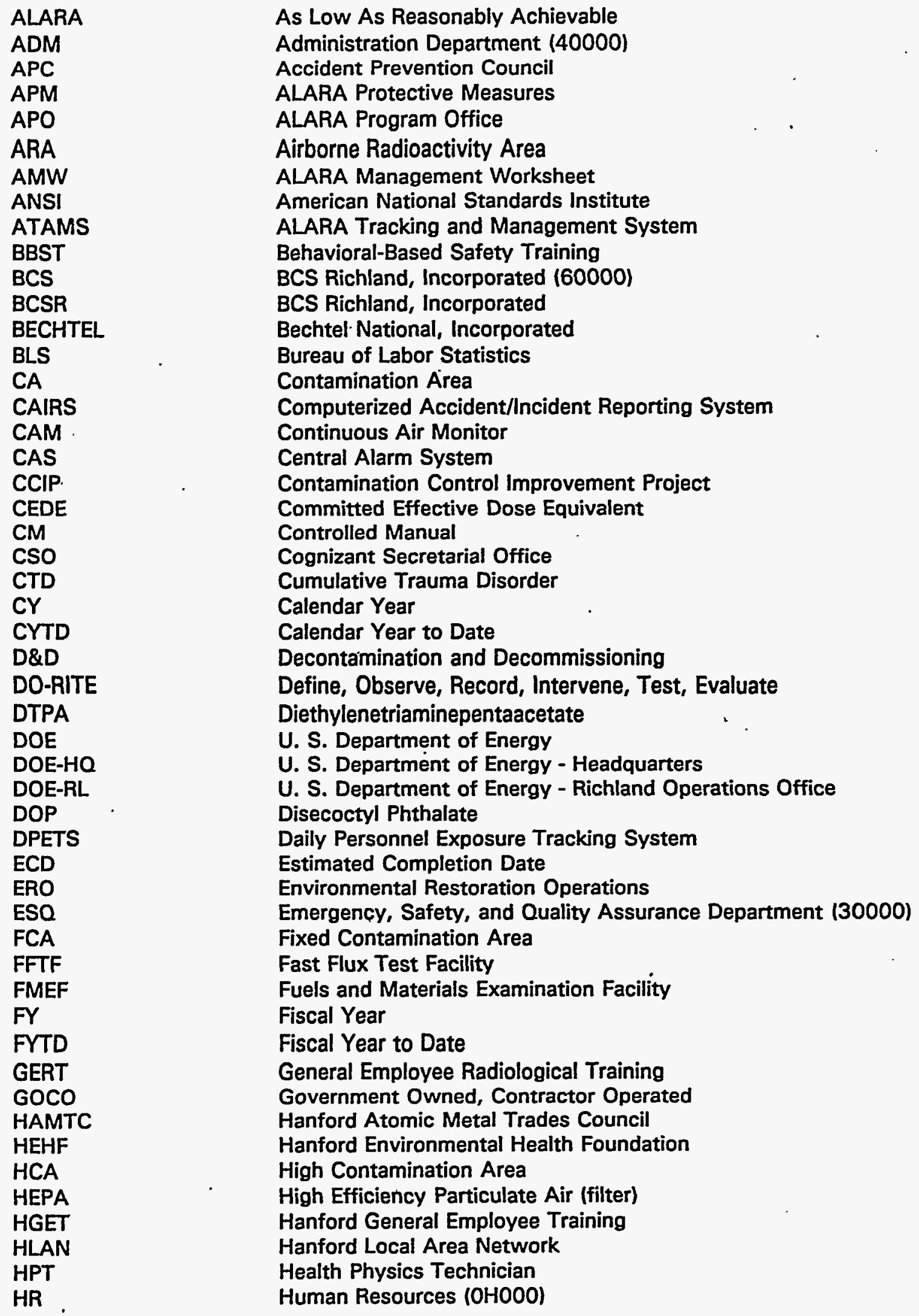




\section{GLOSSARY (Continued)}

HRA HSRCM

IAEA

ICF KH

IHP

LWC

LWD

MACTC

MSDS

NRC

ORPS

OSHA

OSS

PAL

PAPC

PAR

PFP

PIC

PNL

PPE

PPG

PRF

PSS

PUREX

QUEST

RA

REX

RMA

RPR

RWD

RWP

SCA

SHARE

SIP

SNF

STS

SWD

SWP

TLD

TRC

TRP

TWR

TWRS

VPP

WAE

WEC

WESF

WHC

WID

WINCO

WRAM

WSRC

WVNS
Human Resources and Administration Department

Hanford Site Radiological Control Manual

International Atomic Energy Agency

ICF Kaiser Hanford Company (50000)

Industrial Hygiene Programs

Lost Workday Case

Lost Workday

MAC Technical Consultants

Material Safety Data Sheet

Nuclear Regulatory Commission

Occurrence Reporting and Processing System

Occupational Safety and Health Administration

Operations Support Services

Processing and Analytical Laboratories

President's Accident Prevention Council

Post ALARA Review

Plutonium Finishing Plant

Person In Charge

Pacific Northwest Laboratory

Personal Protective Equipment

Priority Planning Grid

Plutonium Reclamation Facility

Projects \& Site Services $(80000$ - 85000)

Plutonium-Uranium Extraction (Facility at Hanford Site)

Quality, Environmental, Safety Tracking

Radiological Area

Radiological Exposure System

Radioactive Materials Area

Radiological Problem Report

Restricted Workday

Radiation Work Permit

Surface Contamination Area

Search Hanford Accessible Reports Electronically

Safety Improvement Plan

Spent Nuclear Fuel Project (20000)

Strategic Affairs/Technical Support (OMO00)

Solid Waste Disposal (87000)

Special Work Permit (clothing)

Thermoluminescent Dosimeter

Total Recordable Cases

Transition Projects Department (10000)

Tank Waste Remediation Systems Department (70000)

Tank Waste Remediation System

Voluntary Protection Program

Waste Analytical and Environmental Department (80000)

Westinghouse Electric Corporation

Waste Encapsulation and Storage Facility

Westinghouse Hanford Company (Richland, WA)

Waste Isolation Division (Carlsbad, NM)

Westinghouse Idaho Nuclear Company (Idaho Falls, ID)

WHC Radiation Area Monitoring

Westinghouse Savannah River Company (Aiken, SC)

West Valley Nuclear Services Company (West Valley, NY) 
WHC-SP-0564-37

\section{GLOSSARY (Continued)}

\section{DEFINITIONS OF TERMS}

Days Away From Work (LWD). Unable to be present in the work environment during the normal work shift as a result of a job-related injury/illness.

First Aid. A nonrecordable occupational injury/illness involving one-time treatment and/or subsequent observation, not ordinarily requiring medical care, even though treatment may be provided by a physician or medically trained person.

Insufficient Volumes. Workers did not provide an acceptable amount of urine for the requested analysis.

Lost Containers. Workers did not return the urine sample containers to the analytical laboratory, or the containers were deficient.

Lost in Laboratory. The analytical laboratory lost the urine sample during the processing.

Lost Workday. A recordable case where the employee cannot perform any or all of normal job duties. Lost workdays include both days away from work and/or days with restricted work activity as defined under "Restricted Workday."

Motor Vehicle Incidence Rate. Number of recordable government motor vehicle accidents $\mathrm{x}$ $1,000,000$, divided by actual vehicle miles driven.

Motor Vehicle Dollar-Loss Rate. Government motor vehicle dollar loss $\times 1,000$, divided by actual vehicle miles driven.

No Sample. Workers did not provide a urine sample for a delivered container.

No Show. Worker did not appear for a scheduled medical or test appointment.

Qccupational Iniurv/lllness Incidence Rate. Incidence rates represent the number of occupational injuries/illnesses per 100 full-time workers and were calculated as: (N/EH) X 200,000 where: $N=$ number of injuries/illnesses; $E H=$ total hours worked by all employees during the reporting period; 200,000 = base for 100 equivalent full-time workers (working 40 hours per week, 50 weeks per year).

Organization Code. The organization to which the employee was officially reporting at the time of the report.

Property Loss Rate. Actual government property damage (fire or nonfire) dollar loss $x$ 10,000 , divided by property dollar valuation.

Recordable Case. An occupational injury/illness resulting in one or more of the following: a fatality, lost workdays, loss of consciousness, restricted work or motion, bone fracture, medical treatment beyond first-aid, transfer to another job, termination of employment, or any iliness diagnosed by a physician as work related.

Restricted Workday. Physically or mentally unable to perform all or any part of normal work assignment during all of any part of the normal workday or shift. These are cases where the employee was: 1) Assigned another job on a temporary basis; 2) Worked at a permanent job less than full time: or 3) Worked at permanently assigned job but could not perform all duties normally connected with it.

Severity Rate. Severity rates represent the number of days lost or restricted per 100 fulltime workers and were calculated as: (N/EH) X 200,000 where $N=$ number of days lost or restricted; $\mathrm{EH}=$ Total hours worked by all employees during the reporting period; $200,000=$ base for 100 equivalent full-time workers (working 40 hours per week, 50 weeks per year). 
WHC-SP-0564-37

This page intentionally left blank.

GL-4 
WHiC-SP-0564-37

\section{DISTRIBUTION}

Number of Copies

5 U. S. Department of Energy Headquarters (To put in Pouch Mail to Germantown, MD)

J Connelley
W Eckroade
M Gavrilas-Guinn
RH Lasky
CS O'Dell

EH-411

EH-32.1

EM-25

EH-32.1

17 Richland Field Office

DH Alexander
DS Atri
ST Burnum
JE Cavanaugh
DL Clark
RA Douglas
L Erickson
JB Hall
EW Higgins
JE Mecca
CA Meyers
RL Nelson
DL Rice
WB Scott
AB Sidpara
AD Toth
DJ Williams

S7-51

A5-55

S7-53

H4-83

A5-55

A5-52

H4-83

A5-55

A5-58

R3-78

S7-54

A5-55

A5-55

A5-55

S7-54

S7-54

S7-54

1 Bechtel Hanford Incorporated

JE Tarpinian

H4-87

6 Hanford Environmental Health Foundation

R Dowray

H1-02

$J$ Hein

H1-76

RH Ronish, MD (4)

H1-75

3 Defense Nuclear Facility Safety Board

SA Stokes

JW Troan

DM Winters

1 Lockheed Idaho Technologies Company

GG Hall 
WHC-SP-0564-37

Number of Copies

\section{DISTRIBUTION (Continued)}

$6 \quad$ MAC Technical Services

GA Gossell

R3-82

CK Kirk

B1-42

MJ Lacey

A4-35

JR McFadden

A4-35

CP Saget

R3-77

JR Yesberger

A4-35

$7 \quad$ Pacific Northwest Laboratory

$\begin{array}{ll}\text { VL Berndt } & \text { A3-60 } \\ \text { HN Bowers } & \mathrm{K} 8-38 \\ \text { TD Chikalla } & \mathrm{P} 7-75 \\ \text { JJ Fix } & \mathrm{P} 7-01 \\ \text { GR Hoenes } & \mathrm{P} 7-79 \\ \text { JR Johnson } & \mathrm{K} 3-53 \\ \text { LH Munson } & \mathrm{K} 3-56\end{array}$

1 Professional Analysis, Inc.

BG Watkins

A2-19

$1 \quad$ Brookhaven National Laboratory

BJ Dionne

1 Westinghouse Electric Corporation

JL Gallagher

12 Westinghouse GOCO Radiation Health Protection Committee

CW Bickerstaff - Westinghouse Electric Corporation

B Bindi - Westinghouse Electric Corporation

FB Davis - Westinghouse Savannah River Company

L Fitch - Waste Isolation Division

D Harward - West Valley Nuclear Services

BG Holmes - Westinghouse Electric Corporation

D Kump - Waste Isolation Division

N Mims - Westinghouse Savannah River Company

DJ Newland - Westinghouse Hanford Company

TF Pointer - Westinghouse Idaho Nuclear Company

AL Trego - Westinghouse Hanford Company

J Volpe - West Valley Nuclear Services Company

5 Westinghouse GOCO Industrial Hygiene and Safety Committee

CL Cabbil - Westinghouse Savannah River

P Hoffman - Westinghouse Waste Isolation Division

RJ Kobelski - Westinghouse Hanford Company

J Volpe - West Valley Nuclear Services

D Whittier - Westinghouse Electric Corporation

Distr - 2 
DISTRIBUTION (Continued)

Westinghouse Hanford Company

SE Albin

TM Amundson

LD Arnold

RW Bailey

JD Bateman Jr.

$A D$ Bates

BL Baumann

GD Bazinet

DD Beers

LG Bennett

OD Berglund

GJ Boehnke

RR Borisch

WM Bricker

LC Brown

HL Budweg

DE Bullock

CL Caldwell

VL Conley

GW Cramer

DS Cunningham

LS Dahlin

CR Davis

HL Debban

WA Decker Jr.

GL Dunford

GL Eaton

RH Engelmann

RA Eschenbaum

LJ Estey

DL Fischer

BG Foreman

MR Fox

RL Fritz

RC Funderburg

RG Gana

JL Gilbert

SS Glover

R Gonzales

HA Gouge

KW Gray

GB Griffin

DS Gunnink

JW Hagan

DW Hamilton

WH Hamilton Jr.

DG Hamrick

MS Hardman

GS Hauger

AR Hawkins

RE Heineman Jr.

DR Henry

RF Hilton
T1-06

N2-10

B2-35

S5-66

B3-59

H4-19

TO-06

S4-53

T7-37

S2-98

T7-37

N1-88

R3-56

N1-06

L5-62

G7-11

T4-09

N1-48

S5-58

L4-13

s0-06

55-72

T4-04

L6-25

T0-06

S7-84

G6-71.

H6-26

S2-66

R3-56

A3-93

S5-65

B2-17

B4-08

S2-31

X8-29

B4-68

R3-01

S2-37

G6-20

T5-57

N2-34

G6-71

B5-20

S7-15

T4-05

S6-15

G7-11

54-39

B5-20

S6-65

S2-41

B4-05
Number of Copies 124

$\begin{array}{ll}\text { JE Hodgson } & \times 7-02 \\ \text { TW Hogg } & \text { T7-37 } \\ \text { CE Hogue } & \text { L6-41 } \\ \text { JH Hummer } & \text { G2-02 } \\ \text { MB Jaeger } & \text { L4-02 } \\ \text { SR Johnson } & \text { T7-37 }\end{array}$

JL Juette $\quad$ G6.56

DP Kerwick R2-88

DR Kibbe R2-40

JR Knight $\quad H 6-30$

VL Llewellyn T0-06

DA Lupkes A3-93

JE Lindsey R3-12

RR Loeffler S5-66

BH Lueck T7-37

RL Martin T3-01

DL McCauley S2-41

HE McGuire B3-63

WJ McKenna B3-30

DW Medley R3-12

CA Meldrom Jr. T5-02

SL Metzger T3-28

BS Mewes T7-05

JC Midgett N2-51

CT Miller, III X3-72

TG Miller, III S5-65

RJ Murkowski G6-13

LL Myers B3-07

DJ Newland T7-37

DR Nunamaker T4-08

GD O'Brien E6-61

AM Ostby T5-03

LD Padilla $\quad$ G1-45

WL Parnell T4-08

BL Poorman $\quad$ S5-08

PR Prevo N1-72

DN Price $\quad 57-80$

DP Reber T4-08

RD Redekopp T5-50

WE Ross \$5-07

JM Sanders $\quad$ S2-98

NL Sant S5-58

ML Sawyer G6-71

FD Schlien T4-05

JP Schmidt $\quad \times 3-78$

JB Shannon S6-71

JL Shelor R2-36

GE Skaare N1-83

RN Smith S6-65

WL Smoot $\quad$ LO-17

JM Steffen N1-47

EL Stairet $\quad$ S2-41

DJ Swaim B3-51 
WHC-SP-0564-37

\section{DISTRIBUTION (Continued)}

TC Synoground

MD Talbot

RJ Thomas

MC Thompson

AL Trego

J Vaughn

EC Vogt

EP Vodney

SF Waters

RL Watts

DL Wegener

KR Whitted

SL Wilkinson

RM Wise

DC Zimmerman

OSTI (2)

Central Files
T3-28

T5-52

T4-20

T6-14

B3-01

H4-87

T5-50

B3-50

S5-60

L6-52

S5-03

S2-41

S2-42

N1-98

S3-97

ᄂ8-07

L8-04

10 Extras $\$ 2-41$

14 Health Physics Field Offices 
WHC Health and Safety Performance Report Distribution:

Thank you for participating in the survey attached to the Fourth Quarter Calendar Year 1994 Health and Safety Performance Report (HSPR). The assessment of the survey revealed useful information and several ideas to be implemented in future issues of the report.

The purpose of the survey was to: Update the distribution, determine if individuals need the report, determine if the customer has additional needs, and to provide an instrument for customers' critique. A cost savings is already being realized by combining Industrial Safety, Industrial Hygiene, and Radiological Control required performance indicators in one document and now further savings can be made with the smaller distribution and more condensed data.

Out of the 280 surveys distributed, there were 118 responses. There were 81 comments on the report: $84 \%$ positive (59\% - Useful, $13 \%$ - Good and Useable, 12\% - Outstanding) and 16\% negative (9\% - Constructive Criticism, 7\% - Negative/Discontinue). The numerous auditors and readiness review preparers, receiving the report at different times throughout the year on a one-time basis, have not been formally surveyed but have responded favorably.

Generally, senior management views the information as "old news" and prefers the daily and/or weekly safety reports. This is understood and it should be noted that this quarterly report was not meant to replace these more timely reports, but rather to enhance the overall scope of understanding of the data provided.

Survey Comment Frequency

\begin{tabular}{|l|c|c|c|c|c|}
\hline \multicolumn{1}{|c|}{ Respondee } & $\begin{array}{c}\text { Negative, } \\
\text { Discontinue }\end{array}$ & $\begin{array}{c}\text { Constr. } \\
\text { Criticism }\end{array}$ & Useful & $\begin{array}{c}\text { Good \& } \\
\text { Useable }\end{array}$ & $\begin{array}{c}\text { Out- } \\
\text { standing }\end{array}$ \\
\hline \hline Level 1 \& 2 Managers & 2 & 4 & 10 & 0 & 1 \\
\hline Other Managers & 3 & 4 & 14 & 6 & 3 \\
\hline Engineer, Accountant, etc. & 1 & 0 & 18 & 4 & 3 \\
\hline Offsite & 0 & 0 & 8 & 1 & 3 \\
\hline \hline Total & 6 & 8 & 50 & 11 & 10 \\
\hline
\end{tabular}

Those discontinuing distribution of the report gave the following reasons.

30 No reason given

8 Will share with others

4 Job change; no longer needed
3 Not useful

3 No longer with company

2 Data of use is tracked elsewhere

Comments on the contents include:

45 Report is valuable and useful

11 Sec. 1 and 3 in particular found useful

7 Report is considered of little or no value

6 Section 2 in particular found useful
6 Extremely useful for trending

2 Job changed, not useful any longer

1 Provides compliance status

1 Still evaluating 